NISTIR 6315

\title{
Supporting Document for Rehabilitation Cost Estimates of FEMA Existing Buildings
}

H. S. Lew

Building and Fire Research Laboratory

Gaithersburg, Maryland 20899

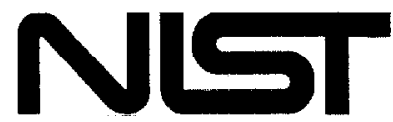

United States Department of Commerce

Technology Administration

National Institute of Standards and Technology 


\section{Supporting Document for Rehabilitation Cost Estimates of FEMA Buildings}

\section{H. S. Lew}

Building and Fire Research Laboratory

National Institute of Standards and Technology

Gaithersburg, MD 20899

Prepared for

Federal Emergency Management Agency

Washington, D.C. 20472

March 1999

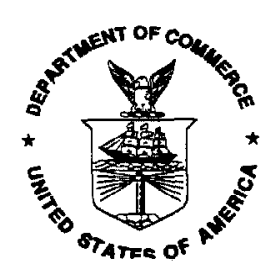

U.S. Department of Commerce

William M. Daley, Secretary

Technology Administration

Gary R. Bachula, Acting Under Secretary for Technology

National Institute of Standards and Technology

Raymond G. Kammer, Director 


\section{PREFACE}

Pursuant to Executive Order 12941, Seismic Safety of Existing Federally Owned or Leased Buildings, all Federal agencies are required to inventory their owned and leased buildings, and to estimate the costs of mitigating unacceptable seismic risks in that inventory. The National Institute of Standards and Technology (NIST) performed these requirements for the Federal Emergency Management Agency (FEMA) under contract EMW-96-IA-0184.

The building data were collected and tabulated by Ann Bieniawski. Field evaluation of the selected buildings were performed by Drs. H. S. Lew and Michael Riley of NIST and Professor Bijan Mohraz of the Southern Methodist University who was on an "Intergovernmental-Personnel-Act" appointment at NIST. The buildings were evaluated jointly by Dr. Lew and Prof. Mohraz. 


\begin{abstract}
This report presents the results of seismic evaluation and cost estimates carried out by the National Institute of Standards and Technology (NIST) for rehabilitation of existing buildings owned by the Federal Emergency Management Agency (FEMA). The seismic evaluation and rehabilitation cost estimates were carried out in response to Executive Order 12941, Seismic Safety of Federally Owned or Leased Buildings. The seismic evaluation was performed based on ICSSC RP4, Standards of Seismic Safety for Existing Federally Owned or Leased Buildings and Commentary, and FEMA 178, NEHRP Handbook for the Seismic Evaluation of Existing Buildings. Rehabilitation costs were estimated using FEMA 156 and 157, Typical Costs for Seismic Rehabilitation of Existing Buildings, Second Edition, Volumes 1 and 2.
\end{abstract}

FEMA owns 137 buildings. Of these, 125 buildings are located in Maryland and Virginia (low seismic regions). Ten buildings were selected for evaluation, of which seven are located in Maryland and Virginia, two in Massachusetts (moderate seismic region), and one in Washington (high seismic region).

All sites where the 10 buildings are located were visited by the NIST team. None of these buildings has a complete set of architectural and structural drawings, particularly old buildings such as those at the Emmittsburg, Maryland site. For those buildings which are judged to have deficiencies according to the checklist in FEMA 178, additional analyses were carried out to determine whether in-situ structures are adequate for "life safety." If passed for life safety evaluation, the structure is judged to have no deficiencies.

Rehabilitation costs for the non-evaluated buildings were derived from the rehabilitation costs of the evaluated buildings. The location of building is considered in the estimation of the rehabilitation cost. The cost estimates are also adjusted to 1998. The rehabilitation costs include structural, non-structural, finishing and administration costs. The total estimated rehabilitation cost for the FEMA buildings is $\$ 13910000$.

Keywords: buildings; costs; evaluation; existing; rehabilitation; seismic damage; structural performance; survey. 


\section{TABLE OF CONTENTS}

Preface

Abstract

1. Introduction

2. Inventory of FEMA buildings

3. Buildings for Essential Designation

4. Buildings for Exceptionally High Risk Designation

5. Selection of Buildings for Evaluation

5.1 Screening process

5.2 Selection process for buildings for evaluation

6. Seismic Evaluation of Buildings

7. Rehabilitation Costs of Evaluated Buildings

8. Rehabilitation Costs of Non-evaluated Buildings

8.1 Assumptions

8.2 Cost estimate procedures

8.3 Rehabilitation costs

9. Building Inventory Data Base

Attachment A: Building Inventory

Attachment B: Seismic Evaluation and Rehabilitation Cost Data

Attachment C: Building Inventory and Rehabilitation Cost Database 


\section{Introduction}

Executive Order 12941, Seismic Safety of Federally Owned or Leased Buildings, requires that Federal agencies develop a complete inventory of their owned and leased buildings, evaluate owned buildings for seismic performance, and develop cost estimates to rehabilitate those buildings found to be seismically deficient. The inventory, evaluations and cost estimates are to be completed following guidance published by the Interagency Committee on Seismic Safety in Construction (ICSSC) as RP4, Standards of Seismic Safety for Existing Federally Owned or Leased Buildings and Commentary; RP5, ICSSC Guidance on Implementing Executive Order 12941 on Seismic Safety of Existing Federally Owned or Leased Buildings; and TR-17, How-to Suggestions for Implementing Executive Order 12941 on Seismic Safety of Existing Federal Buildings, A Handbook.

This report presents the inventory of the FEMA buildings, the selection of buildings for evaluation, the descriptions and evaluation results of the evaluated buildings, and the rationale and process used to estimated the cost of rehabilitation of non-evaluated buildings. In addition to this written document, the inventory and cost data are prepared in electronic form which could be used in the Federal government-wide inventory and seismic rehabilitation cost development.

\section{Inventory of FEMA Buildings}

FEMA provided a list of sites where they owned buildings. The NIST personnel collected the building inventory data from the site representatives either by visits or by telephone. Because the Berryville, Virginia and Emmittsburg, Maryland sites had more than 90 percent of the FEMA buildings, these locations were visited.

A total of 137 buildings that FEMA owns are distributed as follows.

$\begin{array}{llr}\text { - } & \text { Berryville, Virginia - } & 87 \\ \text { - } & \text { Bothell, Washington - } & 1 \\ \text { - } & \text { Denton, Texas - } & 6 \\ \text { - } & \text { Emmittsburg, Maryland - } & 38 \\ \text { - } & \text { Olneynard, Massachusetts - } & 2 \\ & \text { Olney, Maryland - } & 3\end{array}$

A database of the building inventory was created and is attached with this report (Attachment A). This inventory includes all buildings listed in descending order of the "State Code." Other pertinent information about the buildings as specified in Section 2.3 of RP5 are also given according to the format described in Section 5.0 of TR-17.

This database identifies that forty-five (33\%) of the buildings are exempt from seismic evaluation per RP4, Section 1.3. The reasons for exemption are given in the database 
according to Table 5-2 of TR-17. The most common reason for exemption is that a building has only occasional human occupancy.

It should be pointed out that there are approximately 33 buildings at the Berryville, Virginia site, which are classified. These buildings are not part of the 137 buildings mentioned above, and are not included in the database.

\section{Buildings for Essential Designation}

Section 2.3 of RP5 defines essential buildings as those buildings which require a level of seismic resistance that is higher than life safety. These buildings have been designated in the database with an essential building code of $Z 1$. Buildings which are recommended for this designation are listed in Table 1. Buildings which are on an historical registry are not included in this table. These buildings may need to be evaluated to a standard which is higher than life safety depending on the historical preservation requirements.

\begin{tabular}{|l|l|l||}
\hline \multicolumn{3}{|c|}{ Table 1 - Buildings Recommended for Essential Designation } \\
\hline \hline \multicolumn{1}{|c|}{ BUILDING NAME } & \multicolumn{1}{|c|}{ LOCATION } & \multicolumn{1}{c|}{ FUNCTION } \\
\hline Building 311 & Berryville, Virginia & Fire pumping station \\
\hline Building 331 & Berryville, Virginia & Houses emergency power \\
\hline Building 420 & Berryville, Virginia & Fire station \\
\hline Bothell VSAB* & Bothell, Washington & MERS** garage and office \\
\hline Denton Federal Regional Center & Denton, Texas & Communications center \\
\hline Denton VSAB-Old & Denton, Texas & MERS garage and office \\
\hline Denton VSAB \#2 & Denton, Texas & MERS garage and office \\
\hline Maynard Federal Regional Center & Maynard, Massachusetts & Communications center \\
\hline Maynard VSAB & Maynard, Massachusetts & MERS garage and office \\
\hline Olney Federal Support Center & Olney, Maryland & Communications center \\
\hline
\end{tabular}

* VSAB: Vehicle Storage and Administration Building

**MERS: Mobile Emergency Response System

\section{Buildings for Exceptionally High Risk Designation}

Section 3.1 .1 of RP5 recommends that agencies identify all of their "exceptionally high risk" (EHR) buildings for evaluation. According to the guidance on identifying such 
buildings in Section 3.1.1 of TR-17, the following buildings are identified as EHR buildings.

- $\quad$ Bothell VSAB at Bothell, Washington

(MERS garage in a high seismic zone.)

- $\quad$ Maynard VSAB at Maynard, Massachusetts

(MERS garage in a moderate seismic zone.)

Both buildings are essential buildings that house emergency response vehicles, and have unreinforced and partially reinforced concrete masonry walls.

\section{Selection of Buildings for Evaluation}

\subsection{Screening Process}

Buildings were screened after the completion of a Data Collection Sheet for each building. The information on the Data Collection Sheet was compiled during site visits and by telephone conversations with the site personnel. Exempt buildings were identified using the exemption criteria listed in Section 2.2.4 of TR-17. If a building met one of these exemption criteria but was on an historical registry or eligible to be on an historical registry, was designated as an essential building, or performed an industrial function (e.g. sewage pumping station), the building was not exempted. Forty five buildings are classified as "Exempt" for evaluation and are identified with "Exemption Code" of other than EO in the inventory sheets (Attachment A).

\subsection{Selection Process of Buildings for Evaluation}

Section 3.1 of TR-17 recommends that agencies identify buildings for seismic evaluation in two categories. The first category is those buildings designated by the agency as "exceptionally high risk" (EHR). The EHR buildings have been identified in Sect. 4 .

The second category of buildings to be identified for evaluation is a representative sample of the remaining non-exempt population. The guidance states that buildings in the low seismic areas may be excluded from this group. However, because the majority of FEMA's buildings are in the low seismic areas, they are included in developing the representative sample.

FEMA owns two buildings in a moderate seismic area. These buildings are the Maynard Federal Regional Center and the Maynard VSAB. Both of these buildings have been recommended for seismic evaluation as the moderate area sample. Also, both are representative of the underground Regional Centers and the VSAB garages at other sites. 
In the low seismic areas, FEMA owns 89 non-exempt buildings. In order to identify buildings for seismic evaluation, these buildings were divided into model building type and site. A total of six buildings were chosen between the Emmittsburg, Maryland site and the Berryville, Virginia site because the majority of buildings are located at these sites. Each specific building was chosen as a representative sample of the buildings on that particular site with that particular model building type. Whether or not a building was historic was also considered. Therefore, the following ten buildings at four sites were identified for evaluation:

\begin{tabular}{|c|c|c|c|c|c|}
\hline $\begin{array}{l}\text { BUILDING } \\
\text { NAME }\end{array}$ & LOCATION & STRUCTURE & FUNCTION & $\begin{array}{l}\text { SIZE } \\
\left(\mathbf{m}^{2}\right)\end{array}$ & $\begin{array}{l}\text { YEAR } \\
\text { BUILT }\end{array}$ \\
\hline Building 411 & $\begin{array}{l}\text { Berryville, } \\
\text { Virginia }\end{array}$ & steel light frame & $\begin{array}{l}\text { office and } \\
\text { conference center }\end{array}$ & 819 & 1974 \\
\hline Building 420 & $\begin{array}{l}\text { Berryville, } \\
\text { Virginia }\end{array}$ & unreinforced masonry & fire station & 703 & 1955 \\
\hline Building 431 & $\begin{array}{l}\text { Berryville, } \\
\text { Virginia }\end{array}$ & unreinforced masonry & office & 1517 & 1974 \\
\hline Building 704 & $\begin{array}{l}\text { Berryville, } \\
\text { Virginia }\end{array}$ & unreinforced masonry & office & 1848 & 1955 \\
\hline Bothell VSAB & $\begin{array}{l}\text { Bothell, } \\
\text { Washington }\end{array}$ & $\begin{array}{l}\text { comb. rein. masonry \& steel } \\
\text { frame with metal cladding }\end{array}$ & $\begin{array}{l}\text { MERS garage and } \\
\text { office }\end{array}$ & 2787 & 1983 \\
\hline Building D & $\begin{array}{l}\text { Emmittsburg, } \\
\text { Maryland }\end{array}$ & unreinforced masonry & dormitory & 2665 & 1924 \\
\hline Building $\mathbf{J}$ & $\begin{array}{l}\text { Emmittsburg, } \\
\text { Maryland }\end{array}$ & $\begin{array}{l}\text { concrete frame with infill } \\
\text { shear walls }\end{array}$ & $\begin{array}{l}\text { classrooms and } \\
\text { offices }\end{array}$ & 4243 & 1965 \\
\hline Building $O$ & $\begin{array}{l}\text { Emmittsburg, } \\
\text { Maryland }\end{array}$ & $\begin{array}{l}\text { unreinforced masonry - } \\
\text { historic }\end{array}$ & chapel & 1428 & 1839 \\
\hline $\begin{array}{l}\text { Maynard Federal } \\
\text { Regional Center }\end{array}$ & $\begin{array}{l}\text { Maynard, } \\
\text { Massachusetts }\end{array}$ & $\begin{array}{l}\text { underground reinforced } \\
\text { concrete bunker }\end{array}$ & $\begin{array}{l}\text { communications } \\
\text { center and office }\end{array}$ & 7432 & 1968 \\
\hline Maynard VSAB & $\begin{array}{l}\text { Maynard, } \\
\text { Massachusetts }\end{array}$ & $\begin{array}{l}\text { steel light frame with URM } \\
\text { walls and metal cladding }\end{array}$ & $\begin{array}{l}\text { MERS garage and } \\
\text { office }\end{array}$ & 3716 & 1988 \\
\hline
\end{tabular}

\section{Seismic Evaluation of Buildings}

All four sites were visited by the NIST team. A complete set of architectural and structural drawings were not available for all ten buildings. Particularly, drawings for old buildings such as Buildings " $\mathrm{D}$ " and " $\mathrm{O}$ " at Emmittsburg, Maryland show only 
general architectural layout of the buildings.

At each site, the NIST team met a representative who is responsible for the site. The team was briefed about the general history of the building including any remodeling and expansions since the original construction. Both structural and non-structural systems were visually examined. Absence or presence of the lateral load resisting systems and load transfer paths were checked and noted, and a quick evaluation was made at the site to determine the adequacy of the system. Supporting methods for electrical fixtures, suspended ceilings, and air conditioning ducts were examined visually. The condition of mortar of masonry walls was examined by scratching the surface with a nail. No attempts were made to remove any part of the structure to ascertain information on the anchorage and bearing condition of structural members. The exterior of the building was examined to note the general condition of the building, geologic site hazards, adjacency, and soil characteristics.

The buildings were evaluated in accordance with RP4 using the procedure presented in FEMA 178. To clarify evaluation procedures, FEMA 310 (Handbook for the Seismic Evaluation of Buildings- $A$ Prestandard) was also referenced in some cases. The checklists given in Appendix B of FEMA 178 were the basis for evaluation and determination of further analysis if needed. If the structure is not compliant for one of the check list items, further analysis of the structure was carried out to determine whether the structure would satisfy the "life safety" requirement. For those cases where no engineering data are available, conservative assumptions were made on material properties and dimensions based on field observations and measurements.

For each of the ten buildings evaluated, the field data, the evaluation statements (checklists), and if applicable, structural calculations, and costs estimates for rehabilitation are given in Attachment B.

The results of the structural evaluation are given in Table 3.

\begin{tabular}{||c|l|l|c|c||}
\hline \multicolumn{5}{|c|}{ Table 3 - Results of Seismic Evaluation } \\
\hline \hline $\begin{array}{c}\text { BUILDING } \\
\text { NAME }\end{array}$ & LOCATION & \multicolumn{1}{|c|}{ STRUCTURE } & SEISMICITY & $\begin{array}{l}\text { STRUCTURAL } \\
\text { EVALUATION }\end{array}$ \\
\hline \hline Building 411 & $\begin{array}{l}\text { Berryville, } \\
\text { Virginia }\end{array}$ & $\begin{array}{l}\text { MB05 } \\
\text { steel light frame }\end{array}$ & Low & Pass* \\
\hline Building 420 & $\begin{array}{l}\text { Berryville, } \\
\text { Virginia }\end{array}$ & $\begin{array}{l}\text { MB15 } \\
\text { unreinforced masonry }\end{array}$ & Low & Pass \\
\hline Building 431 & $\begin{array}{l}\text { Berryville, } \\
\text { Virginia }\end{array}$ & $\begin{array}{l}\text { MB15 } \\
\text { unreinforced masonry }\end{array}$ & Low & Pass* \\
\hline
\end{tabular}




\begin{tabular}{|c|c|c|c|c|}
\hline Building 704 & $\begin{array}{l}\text { Berryville, } \\
\text { Virginia }\end{array}$ & $\begin{array}{l}\text { MB15 } \\
\text { unreinforced masonry }\end{array}$ & Low & Fail \\
\hline Bothell VSAB & $\begin{array}{l}\text { Bothell, } \\
\text { Washington }\end{array}$ & $\begin{array}{l}\text { MB05 } \\
\text { steel rigid frame }\end{array}$ & High & Pass \\
\hline Building D & $\begin{array}{l}\text { Emmittsburg, } \\
\text { Maryland }\end{array}$ & $\begin{array}{l}\text { MB15 } \\
\text { unreinforced masonry }\end{array}$ & Low & Pass \\
\hline Building $\mathrm{J}$ & $\begin{array}{l}\text { Emmittsburg, } \\
\text { Maryland }\end{array}$ & $\begin{array}{l}\text { MB10 } \\
\text { conc. frame with infill } \\
\text { walls }\end{array}$ & Low & Pass \\
\hline Building $O$ & $\begin{array}{l}\text { Emmittsburg, } \\
\text { Maryland }\end{array}$ & $\begin{array}{l}\text { MB15 } \\
\text { unreinforced masonry }\end{array}$ & Low & Fail \\
\hline $\begin{array}{l}\text { Maynard Federal } \\
\text { Regional Center }\end{array}$ & $\begin{array}{l}\text { Maynard, } \\
\text { Massachusetts }\end{array}$ & $\begin{array}{l}\text { MB } 16 \\
\text { underground RC bunker }\end{array}$ & Moderate & Pass \\
\hline Maynard VSAB & $\begin{array}{l}\text { Maynard, } \\
\text { Massachusetts }\end{array}$ & $\begin{array}{l}\text { MB05 } \\
\text { steel light rigid frame }\end{array}$ & Moderate & Fail \\
\hline
\end{tabular}

* Marginal Pass

\section{Berryville, Virginia}

\section{Building 411}

The floor plan of this one-story building is rectangular. It is $24 \mathrm{~m}(80 \mathrm{ft})$ wide and $34 \mathrm{~m}$ (110 ft) long. A large unobstructed interior space can hold 200 to 250 people for meetings and conferences. The vertical load resisting system is comprised of preengineered and pre-fabricated rigid steel frames. Z-shape purlins spanning between the rigid frames support the metal roof deck. In the plane of the frame, lateral loads are resisted by frame action. The rigid frames are designed for $40 \mathrm{~m} / \mathrm{s}(90 \mathrm{mph}$ ) wind load, and they are adequate for the seismic loads in a low seismic zone.

In the direction perpendicular to the plane of the rigid frames (the longitudinal axis), there is only one pair of diagonal bracing in place between the columns of two adjacent rigid frames along one of the exterior walls. On the opposite side, a section of field stone masonry wall about $6 \mathrm{~m}$ ( $20 \mathrm{ft}$ ) long balances lateral load resistance in the longitudinal direction of the building. In general, most of the exterior walls are clad with metal siding.

If the bracing were to fail, the lateral load in the longitudinal direction of the building would be resisted by the masonry wall alone, and consequently, torsion would be developed. Since the building is located in a low seismic region and the lateral load 
produced by an earthquake is much smaller than the same produced by the design wind load, the likelihood of failure of the diagonal-bracing is small. Thus, this building is judged to have no structural deficiency. However, it is recommended that additional diagonal bracing be installed for improved seismic safety.

\section{Building 420}

This building is a fire station, and designated as an essential building. The floor plan of

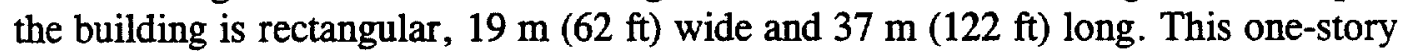
URM (unreinforced masonry) building is comprised of $300 \mathrm{~mm}$ (12 in) partially reinforced concrete masonry walls with continuous bond beams at mid-height and at the top of the four exterior walls. Horizontal reinforcement was placed at all horizontal masonry joints. The roof framing is comprised of steel joists spanning between the exterior masonry walls and a row of steel beams supported on reinforced masonry columns located along the centerline of the building. Built-up roofing is applied on 45 $\mathrm{mm}(2 \mathrm{in})$ concrete roof planks. Steel angle bridgings between steel joists are placed at about $0.8 \mathrm{~m}$ ( $24 \mathrm{in})$ on center. This building is judged to have no deficiency.

\section{Building 431}

The building, constructed in 1974, is currently being used for office and storage. The original floor dimensions were $18 \mathrm{~m}(60 \mathrm{ft})$ wide and $49 \mathrm{~m}$ (160 ft) long. An addition in 1977 increased the width to $31 \mathrm{~m}$ (102 ft). The vertical load resisting system is comprised of long-span joists supported on square tubular steel columns. The roof load is carried by metal deck on Z-shape purlins spanning between the long-span steel joists. The joists span between square tubular columns spaced at $6 \mathrm{~m}(20 \mathrm{ft})$ on center in both directions. When the building was originally built, the perimeter tubular columns were imbedded in the exterior unreinforced masonry walls on all four sides which provided lateral load resistance. When new sections were added to make the building $31 \mathrm{~m}$ (102 $\mathrm{ft}$ ) wide, light steel frames and metal siding replaced the two masonry end walls in the transverse direction. In addition, gypsum wall board partitions framed with $2 \times 4^{1}$ lumber replaced one of the masonry walls in the longitudinal direction. Visual inspection did not reveal any diagonal braces between tubular columns within the wall board partitions. Research has shown that gypsum board walls perform well for in-plane shear loading. Thus, it is judged that even without any diagonal braces, the gypsum wall board partitions are adequate to resist the seismic force generated by light roof load of $1.9 \mathrm{k} \mathrm{Pa}$ (40 psf) which includes $1.4 \mathrm{k} \mathrm{Pa} \mathrm{(30} \mathrm{psf)} \mathrm{of} \mathrm{snow} \mathrm{load.}$

\footnotetext{
${ }^{1} 2 \times 4$ is a designation of dimension lumber $38 \mathrm{~mm} \times 89 \mathrm{~mm}\left(1 \frac{1}{2}\right.$ in $\times 3 \frac{1}{2}$ in) in cross section.
} 
In the transverse direction, the lateral load is resisted by frame action provided by steel joists and tubular columns. Static analysis of the structure indicates that the columns can resist the seismic force with a small margin of safety. Thus, in the transverse direction, the lateral load resistance capacity of this building is marginal. Although the building is judged to have no deficiencies, it is recommended that this building be rehabilitated to improve its expected seismic performance.

\section{Building 704}

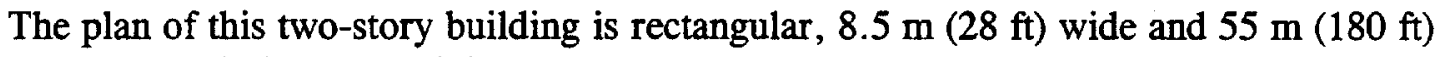
long. The building was originally constructed in 1955 as a dormitory and was remodeled in 1984. The building framing is comprised of wood above the first floor. The exterior walls are unreinforced concrete masonry. Continuous reinforced concrete bond beams of $200 \mathrm{~mm} \times 355 \mathrm{~mm}$ (8 in x $14 \mathrm{in})$ and $140 \mathrm{~mm} \times 355 \mathrm{~mm}$ (5.5 in x $14 \mathrm{in}$ ) are placed around the entire perimeter of the building at the second floor and roof level, respectively. The interior partitions are constructed of $2 \times 4$ wood studs. The $2 \times 8^{2}$ floor joists are spaced at $400 \mathrm{~mm}$ (16 in) on center and the $2 \times 6^{3}$ ceiling joists are spaced at $610 \mathrm{~mm}$ ( $24 \mathrm{in}$ ) on center. At the first floor, the joists are supported on concrete beams. The $2 \times 8$ roof rafters are spaced at $610 \mathrm{~mm}(24 \mathrm{in})$. The ceiling joists are anchored by metal plate to $2 \times 6$ top plates on the masonry wall. In turn, the top plates are anchored

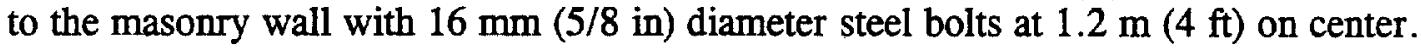
No specific details are shown on the drawing about the anchor condition of floor joists in the masonry walls.

Because of a large aspect ratio (7.2) of the floor plan, the effectiveness of the wood floor diaphragm is checked. The chord is comprised of concrete bond beams. Since the building is located in a low seismic region, the force developed in the chord is relatively small, and analysis shows that the bond beams would function safely as chords. Extreme fiber bending stresses in the plywood floor sheathing is very low 0.7 $\mathrm{MPa}$ (103 psi). Analysis shows that the plywood sheathing would be overstressed in shear if the diaphragm resists the total lateral load on the second floor.

In order for the floor to function as a diaphragm, the floor joists must be anchored adequately in the masonry walls or to the bond beams. A cross section of the building shows that the joists have fire-cut ends at the wall with about $90 \mathrm{~mm}(3 \mathrm{1} / 2 \mathrm{in})$ to 100 $\mathrm{mm}$ ( $4 \mathrm{in}$ ) bearing. Analysis showed that this bearing length may not be adequate for the joists to remain supported in the wall when the floor deflects during an earthquake. Because of inadequacies found in the horizontal load path, both in stiffness and shear

$2,32 \times 8$ and $2 \times 6$ are designations of dimension lumber $38 \mathrm{~mm} \times 190 \mathrm{~mm}\left(1 \frac{1}{2} \mathrm{in} \times 71 / 2\right.$ in) and $38 \mathrm{~mm} \times$ $140 \mathrm{~mm}\left(2 \frac{1}{2}\right.$ in $\times 5 \frac{1}{2}$ in) in cross section, respectively. 
capacities, this building is judged to be deficient.

\section{Bothell, Washington}

\section{Bothell VSAB (Vehicle Storage and Administration Building)}

The floor plan of this one-story garage is an L-shape. The main garage portion is $30 \mathrm{~m}$ $(100 \mathrm{ft})$ wide and $60 \mathrm{~m}$ (200 ft) long. The primary structural frame is comprised of preengineered rigid frames. The frames are spaced at $9 \mathrm{~m}(30 \mathrm{ft})$ on center along the length of the building. There is a two-story office building built at one end of the garage. The two-story steel frame building is structurally independent from the rigid frames. The structure was designed in accordance with the 1982 Army Manual 5-80910 (Tri-Service Manual). This structure was designed in accordance with the seismic design provisions developed after the 1976 Uniform Building Code which incorporated modern seismic design procedures. Therefore, the design of the structures may be considered adequate.

The lateral load resisting system is comprised of diagonal braces between rigid bent columns on one side of the building and partially reinforced masonry wall on the opposite side along the length of the building. Structural ties are provided between the footings which support the rigid bent columns, thereby preventing relative spread of the column bases.

The field investigation identified that the lateral load resisting system in the north-south direction of the west-end bay may be inadequate as the end wall has four large garage doors without any lateral bracing system. The structural framing of this bay is comprised of steel-channel columns and light I-shape beams. Assuming that the resistance to lateral displacement at the top of the end bay is provided by the roof framing, the lateral displacement is computed. The computed value is very small ( 6 $\mathrm{mm}$ ) due to relatively light weight of the structure. Analysis shows that the roof diaphragm has adequate capacity to resist the shear load generated by the lateral displacement of the end bay. Thus, the deficiency of the end bay as identified in the preliminary evaluation using the checklist is removed, and the structure is judged to have no deficiencies.

\section{Emmittsburg, Maryland}

All four buildings evaluated do not have architectural or structural drawings. 


\section{Building D}

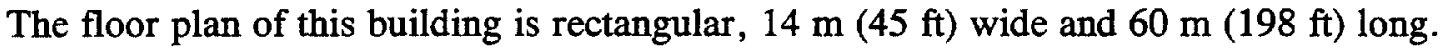
It is a three story unreinforced brick masonry structure built in 1924. The exterior walls are stone masonry and the interior walls are brick. The first floor is comprised of

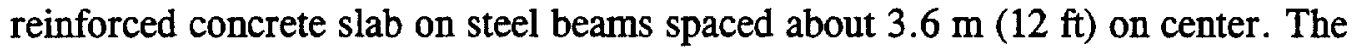
second and third floors and the third floor ceiling are comprised of concrete slab on timber beams. This building has a most unusual roof framing in that it consists of concrete trusses and concrete slab made of fly ash concrete. This results in a large concentration of mass at the roof level. The ratio of the roof mass to the mass of the third floor is about 3.5. This would be a major concern if the building is located in a high seismic region. For a massive brick masonry structure in a low seismic region, it is reasonable to assume that the structure would respond in a first mode of vibration. A shear stress check in the masonry wall at the roof level and at the first floor indicates that the wall has adequate strength to resist horizontal shear. Thus, this building is judged to have no deficiency.

\section{Building J}

Building $\mathrm{J}$ is one wing of a complex of the three separate buildings (two wings and an auditorium) with connecting sections. In general, all three buildings consist of concrete frames and infill shear walls. The buildings were constructed in 1963-1965 and remodeled in 1992-1994. All floors and the roof are comprised of concrete joists. Building J, $18 \mathrm{~m}$ ( $59 \mathrm{ft}$ ) wide and $51 \mathrm{~m}$ (169 ft) long, has a partial basement comprised of reinforced concrete slab and exterior walls. A major concern of this building is the presence of gaps between the infill shear walls and concrete columns along the entire length of the building. Windows are placed in these gaps. No portion of the infill wall was removed during the field investigation to obtain information on wall anchor details to the concrete slab above and below. Due to the existence of the gaps and lack of information on the wall anchor details, the building is rated initially to have deficiencies. Since the building is located in a low seismic region, analysis was made to check whether the concrete frame alone could resist lateral loads without the aid of infill shear walls. The results of a linear elastic finite element analysis show that story drifts are relatively small and the columns have adequate strength to resist the seismic load. Based on the analysis, the building is judged to have no deficiency.

\section{Building $\mathbf{O}$}

This chapel was constructed in 1839 and is on the Historic Register. The building is

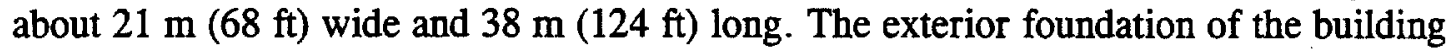
is stone and brick. The exterior walls are $600 \mathrm{~mm}$ ( $24 \mathrm{in}$ ) thick stone masonry and the interior walls are $450 \mathrm{~mm}$ (18 in) thick brick masonry. Timber columns and beams are 
used in the structure. Timber trusses support the wood ceiling over the chapel. The wood lath and plaster ceiling is suspended from the bottom chords of the trusses. The

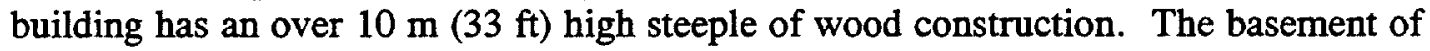
the building was renovated in the late $1970 \mathrm{~s}$, and the timber columns in the basement below the altar were replaced with steel columns. Although the exterior masonry walls have many large window openings which may reduce the shear capacity of the walls, a check of shear stresses in the walls showed that the exterior walls have adequate capacity to resist seismic loads. Careful examination during the field investigation showed that there is no effective load path from the steeple to the foundation. Positive load path must be provided for the steeple to remain stable during an earthquake. For improved seismic safety, it is also recommended that the wood lath and plaster ceiling be replaced with one of lighter mass.

\section{Maynard, Massachusetts}

\section{Federal Regional Center}

This is a two-story underground reinforced concrete structure. The outer dimensions of the structure are $36.5 \mathrm{~m}(120 \mathrm{ft})$ and $43 \mathrm{~m}(14 \mathrm{ft})$. It was designed for nuclear blast loading. All interior fixtures are mounted on springs and shock absorbing cushions. All suspended ceilings are rigidly attached to the concrete slab above. At the present time, there is no generally accepted routine procedure to determine earthquake loading on a buried structure. Review of the structural drawings indicate that structural members, inter-member joints and connections have adequate reinforcement to provide adequate strength and ductility. Since the structure is designed for an event of nuclear blast, it is reasonable to postulate that the structure can be occupied during and after moderate seismic events. This structure is judged to have no deficiency.

\section{Maynard VSAB (Vehicle Storage and Administration Building)}

The floor plan of this one-story garage is L-shape. The main part of the garage (the longer leg of the $\mathrm{L})$ is about $36 \mathrm{~m}(120 \mathrm{ft})$ wide and $82 \mathrm{~m} \mathrm{(270} \mathrm{ft)} \mathrm{long.} \mathrm{The} \mathrm{primary}$ structural system is comprised of pre-engineered rigid steel frames. A square steel tubular column supports the ridge of the rigid frame. At one end of the garage, twostory office spaces are framed using steel beams and columns. The office spaces are enclosed with partially reinforced infill concrete masonry walls. The walls along the building (perpendicular to the plane of the rigid frame) have large garage door openings between two bents. This allows large vehicles to drive through the building between two rigid bents. As a result there are no diagonal braces. Thus, in the direction perpendicular to the plane of the rigid frame (the longitudinal axis of the building), the garage portion of the structure relies on the masonry walls to resist the lateral load. The 
masonry walls have reinforced concrete bond beams at two levels, one at the top of the first story and the other at the top of the second story.

The roof is comprised of steel decks on Z-shape purlins which span between the rigid frames. The out-of-plane stability of the rigid bents is provided by the steel deck and purlins plus steel rope X-bracing in one bay at the roof level. This building lacks a complete load path from the roof to the foundation for the load acting in the longitudinal direction of the building. Analysis shows that the purlins do not have adequate tension capacity to transfer the lateral load generated by the garage portion of the structure to the office portion (masonry walls). Therefore, the roof is deficient in transferring the lateral load to the vertical load resisting members (masonry walls).

\section{Rehabilitation Costs of Evaluated Buildings}

The costs for rehabilitation of the evaluated and seismically deficient buildings are determined according to the instructions given in Section 4 of RP5 following cost estimating Option II in Second Edition-Typical Costs for Seismic Rehabilitation of Existing Buildings, Volume I, FEMA -156 (1994) for structural costs, and procedures in Volume II of Second Edition-Typical Costs for Seismic Rehabilitation of Existing Buildings, FEMA-157(1995) for non-structural costs.

The following assumptions are used in estimating the rehabilitation costs.

1. The rehabilitation cost for historical buildings are estimated by multiplying the cost estimate obtained for the same building assuming "non-historical" by a factor of 3 (Sect. 1.6, FEMA-157).

2. The finishing costs are determined using the values obtained from the difference between "none" and "minimal" columns in Tables 1.1, 1.2, 1.3, and 1.4 of FEMA-157.

3. The project costs are determined by multiplying the sum of the structural, non-structural and finishing costs by 0.3 .

Three of the ten buildings selected for evaluation failed, one of which is a historical building. The cost estimates for failed buildings are given in Attachment B. As required by TR-17, the estimated costs are divided into four categories: structural costs, nonstructural costs, finishing costs, and project costs.

The total rehabilitation cost of the evaluated buildings is $\$ 3843000$. 


\section{Rehabilitation Costs of Non-Evaluated Buildings}

Of 137 buildings in the inventory, 45 building are exempted from seismic evaluation. All eight underground structures in a low seismic zone are assumed to have no deficiencies. Including the Federal Regional Center at Maynard, Massachusetts, nine underground structures are removed from the inventory for seismic evaluation. The inventory has three buildings which are designated as "historical buildings." The rehabilitation costs for these buildings are treated separately. Since eight buildings (non-historic and non-underground buildings) have been evaluated, the rehabilitation costs of 72 non-evaluated buildings $(137-45-9-3-8=72)$ need to be estimated.

\subsection{Assumptions Made for Cost Estimate}

The inventory of buildings revealed that the non-exempt FEMA buildings can be classified into nine different model building types. If an underground bunker and a historic building are treated separately, the evaluated buildings fall into three different model types. They are tabulated below with the associated floor areas. The floor areas in both columns do not contain the areas corresponding to the underground structures and historical buildings.

\begin{tabular}{cc} 
Non-Evaluated Bldg. (Area in $\mathrm{m}^{2}$ ) & Evaluated Buildings (Area in $\mathrm{m}^{2}$ ) \\
\hline MB 01 (2 995) & \\
MB 04 (16 138) & MB 05 (7 322) \\
MB 05 (2 683) & \\
MB 08 (492) & MB 10 (4 243) \\
MB 10 (6 648) & \\
MB 13(1 014) & MB 15 (6 733) \\
MB 14 (702) & \\
MB 15 (111 049) & \\
MB 16(1342) & $18298 \mathrm{~m}^{2}$
\end{tabular}

Only three model building types are evaluated. The non-evaluated buildings that do not correspond to the evaluated building types are $\mathrm{MB} 01,04,08,13,14$, and 16 . However, these types represent a small portion of the total floor area of the non-evaluated buildings $\left(16 \%=22638 \mathrm{~m}^{2} \div 143063 \mathrm{~m}^{2}\right.$ ). It should be noted that none of the buildings in these types are exceptionally high risk buildings, and that all the buildings are located in a low seismic region. Therefore, it is reasonable to assume that the nonevaluated buildings of MB 01,04,08,13,14, and 16 do not need rehabilitation. 


\subsection{Procedure Used for Cost Estimate}

1. Since all non-evaluated MB 05 buildings are in Virginia, the evaluation result of Berryville Building 411 is applied to this group of buildings. Thus, their rehabilitation costs are zero. The VSAB buildings at Maynard, MA and Bothell, WA are garages located in a moderate and a high seismic area, respectively. They are structurally different from the MB 05 buildings in Virginia.

2. Since all non-evaluated MB 10 buildings are located in Emmittsburg, Maryland, and the MB 10 building at that site which was found to pass, it is assumed that the non-evaluated $\mathrm{MB} 10$ buildings do not require rehabilitation.

3. All non-evaluated MB 15 buildings are located in Maryland and Virginia. Excluding one historical building, one of the four evaluated buildings "failed." The area of the "failed" building (Building 704) is about $27 \%$ of the total area of the evaluated MB 15 buildings. The average rehabilitation cost per square meter for the MB 15 buildings is determined by dividing the rehabilitation cost of Building 704 by the total area of the MB 15 buildings, which is $\left(\$ 41795 / 6733 \mathrm{~m}^{2}=\right.$ $\$ 62.07 / \mathrm{m}^{2}$ ).

4. All three historical buildings are located at Emmittsburg, Maryland. Thirty three percent of the average rehabilitation cost of Emmittsburg Building $O$ (chapel) is applied to Buildings $N$ and $Q$ as one is an office building and the other is a barn.

\subsection{Rehabilitation Cost Estimates}

The rehabilitation cost of the evaluated buildings is:

Berryville, Building $704 \$ \$ 418000$

Emmittsburg, Building O \$2471000

Maynard VSAB $\$ \$ 954000$

Total $\$ 3843000$

The rehabilitation cost of the non-evaluated buildings is:

MB 05

MB 15

Others

Historic

Total

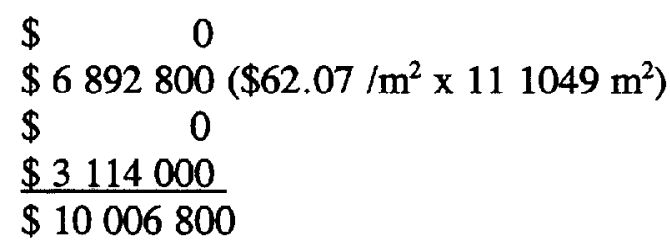


The total estimated rehabilitation cost for the FEMA buildings is:

$\begin{array}{ll}\text { Evaluated Buildings: } & \$ 3843000 \\ \text { Non-evaluated Buildings: } & \$ 10007000\end{array}$

Total $\$ \$ 13910000$

\section{Building Inventory Data Base}

All pertinent data required by RP5 are entered in the database forms according to the instructions given in TR-17. The hard copies of the database forms are attached (Attachment C). The electronic form of the database is also provided in a diskette. 
Attachment A: Building Inventory 


\begin{tabular}{|c|c|c|c|c|c|c|c|c|c|c|c|c|c|c|}
\hline 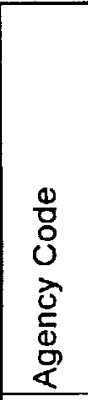 & 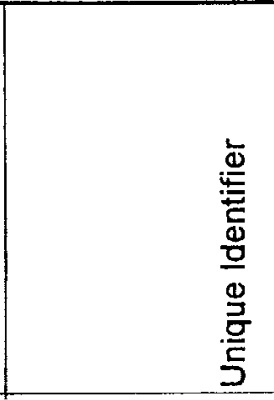 & 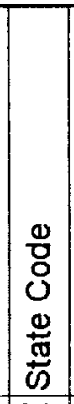 & 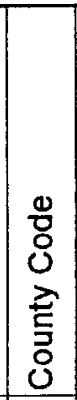 & 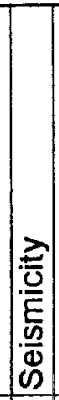 & 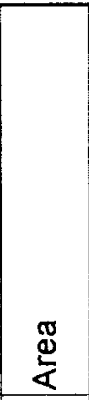 & 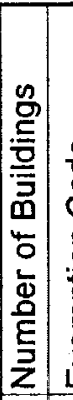 & 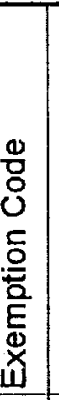 & 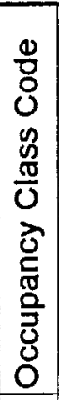 & 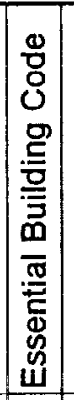 & 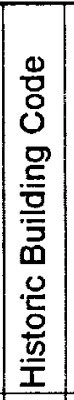 & 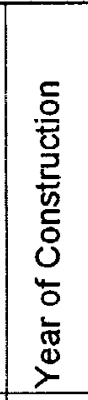 & 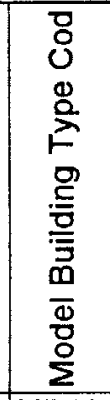 & 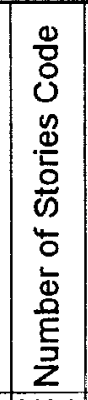 & 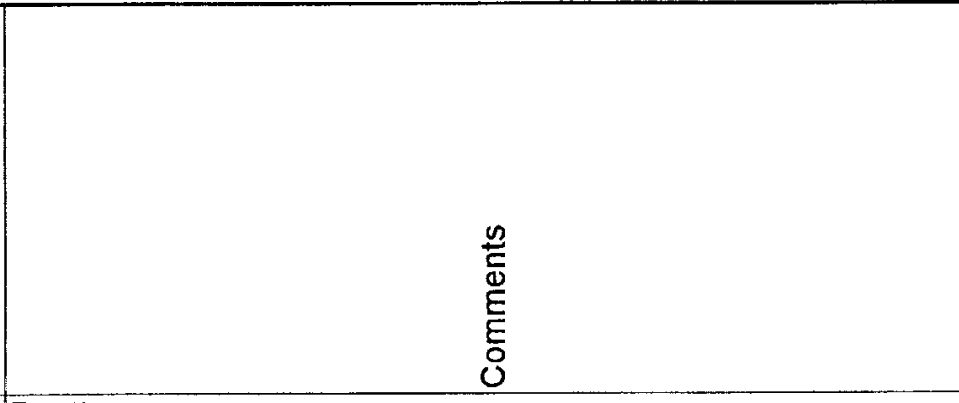 \\
\hline 5800 & Boathouse & 24 & 021 & $L$ & 46 & $1 E$ & E1 & 80 & \begin{tabular}{|l|}
$\mathrm{Z} 2$ \\
\end{tabular} & $\mathrm{H} 2$ & 1960 & MB13 & N01 & Boathouse \\
\hline 5800 & Building $A$ & 24 & 021 & L & 3091 & $1 E$ & EO & 30 & 22 & $\mathrm{H} 2$ & 1965 & MB10 & N03 & \\
\hline 5800 & Building $\mathrm{B}$ & 24 & 021 & $L$ & 541 & $1 E$ & E0 & 80 & $\mathrm{Z2}$ & $\mathrm{H} 2$ & 1956 & MB15 & N01 & \\
\hline 5800 & Building C & 24 & 021 & $L$ & 2492 & $1 E$ & 00 & 30 & 22 & $\mathrm{H} 2$ & 1956 & MB10 & N03 & \\
\hline 5800 & Building C-West & 24 & 021 & $L$ & 4923 & $1 / E$ & 67 & 30 & 22 & $\mathrm{H} 2$ & 1995 & MB14 & N03 & \\
\hline 5800 & Building D & 24 & 021 & $L$ & 2665 & $1 E$ & Eo & 30 & 22 & $\mathrm{H} 2$ & 1924 & MB15 & $\mathrm{NO3}$ & Eligible for historic registry but not officially registered. \\
\hline 5800 & Building $E$ & 24 & 021 & L & 3252 & $1 \mathrm{E}$ & EO & 10 & $\mathrm{Z2}$ & $\mathrm{H} 2$ & 1923 & MB15 & N03 & $\begin{array}{l}\text { Contains an auditorium which can seat } 500 \text {; Eligible for historic } \\
\text { registry but not officially registered. }\end{array}$ \\
\hline 5800 & Building F & 24 & 021 & $L$ & 1875 & $1 \mathrm{E}$ & E0 & 30 & 22 & $\mathrm{H} 2$ & 1926 & MB15 & N03 & Eligible for historic registry but not officially registered. \\
\hline 5800 & Building G & 24 & 021 & $\mathrm{~L}$ & 649 & $1 E$ & E0 & 30 & 22 & $\mathrm{H} 2$ & 1948 & MB15 & N02 & \\
\hline 5800 & Building $\mathrm{H}$ & 24 & 021 & L & 1871 & $1 E$ & $=0$ & 10 & 22 & $\mathrm{H} 2$ & 1923 & MB15 & No3 & $\begin{array}{l}\text { Contains recreation area (swimming pool, basketball court, } \\
\text { weight room) }\end{array}$ \\
\hline 5800 & Building I & 24 & 021 & L & 3344 & $1 \mathrm{E}$ & $E 7$ & 50 & 22 & $\mathrm{H} 2$ & 1996 & MB07 & NO2 & Design looked at Map Area 1 in BOCA and NEHRP \\
\hline 5800 & Building J & 24 & 021 & $\bar{L}$ & 4243 & $1 E$ & EO & 23 & 22 & $\mathrm{H} 2$ & 1965 & MB10 & N02 & Contains an auditorium and offices as well. \\
\hline 5800 & Building $\mathrm{K}$ & 24 & 021 & $L$ & 3786 & $1 E$ & 0 & 23 & 22 & $\mathrm{H} 2$ & 1890 & MB15 & N03 & $\begin{array}{l}\text { Contains a cafeteria which seats about } 350 \text {; eligible for historic } \\
\text { registration but not officially registered. }\end{array}$ \\
\hline 5800 & Building $\mathrm{L}$ & 24 & 021 & $L$ & 1065 & $1 E$ & EO & 30 & 22 & $\mathrm{H} 2$ & 1959 & MB10 & N03 & \\
\hline 5800 & Building M & 24 & 021 & $L$ & 678 & $1 E$ & $=0$ & 23 & 22 & $\mathrm{H} 2$ & 1960 & MB14 & N02 & \\
\hline 5800 & Building $\mathrm{N}$ & 24 & 021 & $L$ & 4449 & $1 \mathrm{E}$ & EO & 10 & 221 & $\mathrm{H1}$ & 1870 & MB15 & N04 & \\
\hline 5800 & Building $\mathrm{O}$ & 24 & 021 & $L$ & 1428 & $1 E$ & EO & 80 & 22 & $\mathrm{H} 1$ & 1839 & MB15 & N02 & \\
\hline 5800 & Building $P$ & 24 & 021 & $L$ & 280 & $1 E$ & E0 & 80 & 22 & $\mathrm{H} 2$ & 1960 & MB16 & N01 & Log Cabin; Can hold 150-200 people for recreational purposes. \\
\hline 5800 & Building Q & 24 & 021 & L & 948 & $1 \mathrm{E}$ & E0 & 40 & 22 & $\mathrm{H1}$ & 1880 & MB15 & N02 & \\
\hline 5800 & Building $\mathrm{R}$ & 24 & 021 & L & 459 & & EO & 23 & 221 & $\mathrm{H} 2$ & 1950 & MB15 & N01 & \\
\hline 5800 & Building S & 24 & 021 & $L$ & 626 & & EO & 80 & 221 & $\mathrm{H} 2$ & 1926 & MB15 & N01 & $\begin{array}{l}\text { Eligible for historic registry but not formally registered; Currently } \\
\text { undergoing major renovations; Will be used as a computer } \\
\text { simulations laboratory. }\end{array}$ \\
\hline 5800 & Building T & 24 & 021 & L & 110 & $1 E$ & $E 0$ & 10 & 22 & $\mathrm{H} 2$ & 1960 & MB15 & N01 & \\
\hline 5800 & Building U & 24 & 021 & L & 156 & $\# \mathbf{E}$ & & 80 & 22 & $\mathrm{H} 2$ & 1982 & MB16 & N01 & $\begin{array}{l}12 \times 14 \text { precast concrete buildings used as arson labs; Built from } \\
1982-1996 \text {. }\end{array}$ \\
\hline
\end{tabular}

Page 1 


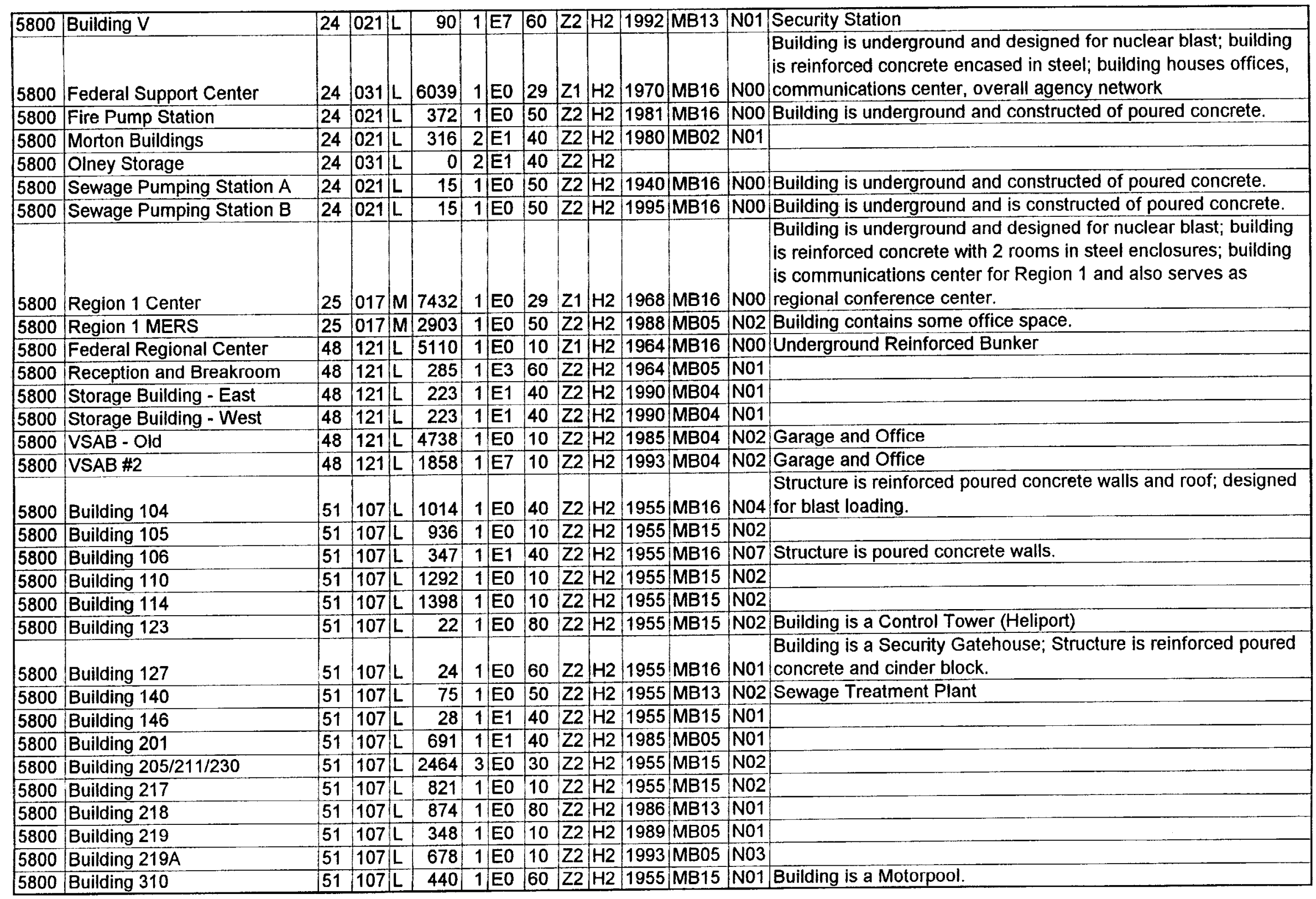




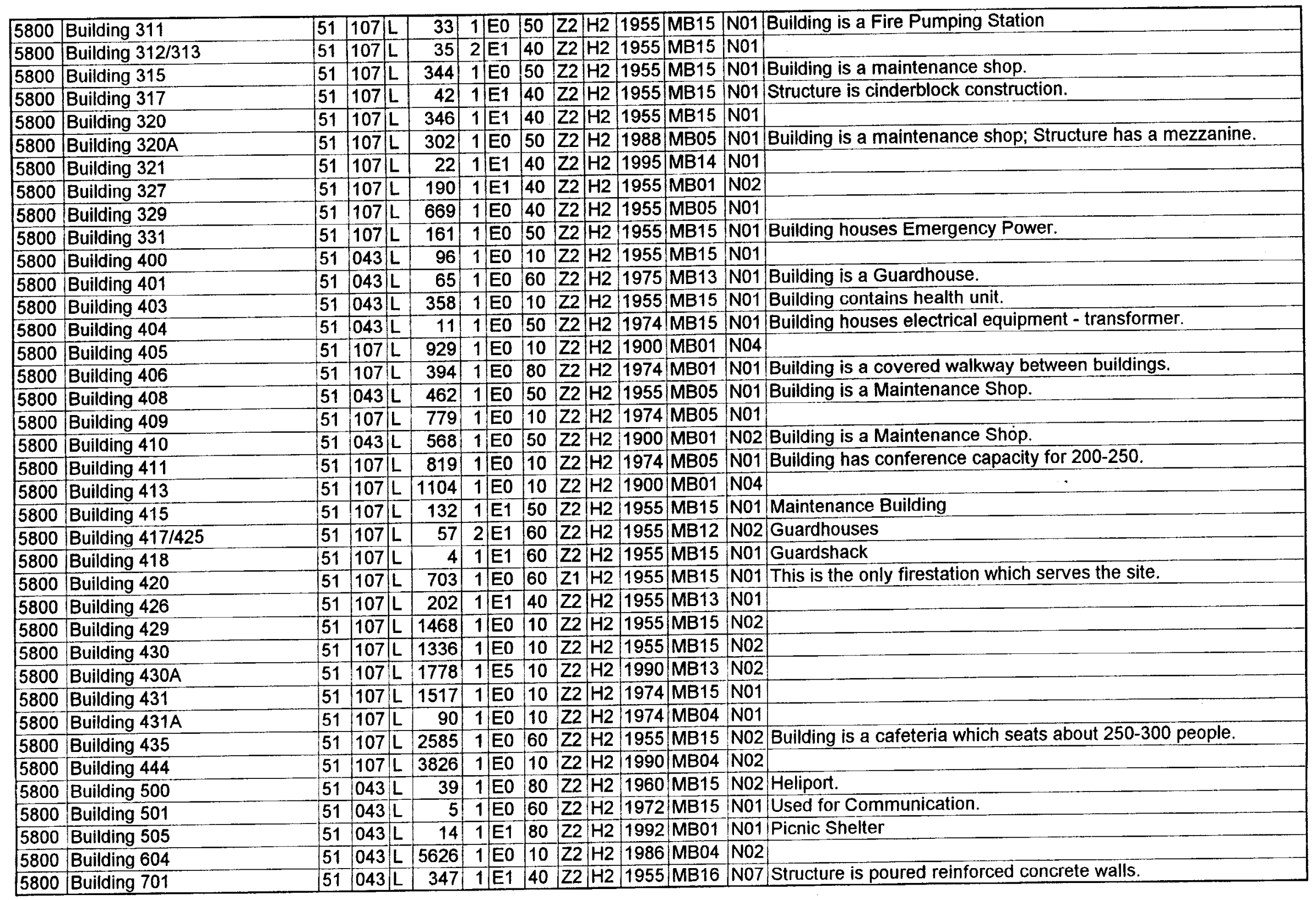




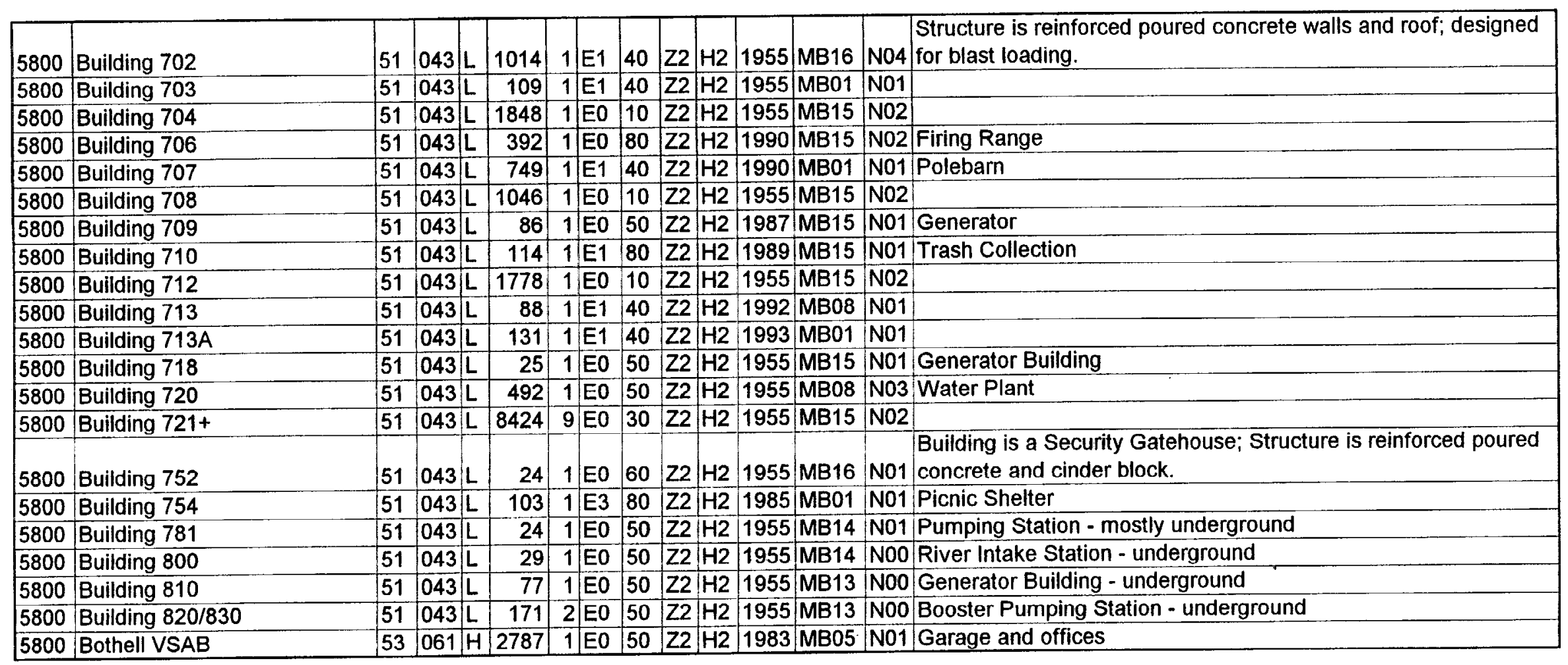


Attachment B: Seismic Evaluation and Rehabilitation Cost Data 
Building Designation :

411

Location: Berry file, VA

DATA SUMMARY SHEET

BUILDING DATA

Year built: $1974 \quad$ Years) remodelled: -

Date of Evaluation: $8 / 5 / 98$

Area, (sq. ft.) 8816 Length $110^{\prime}$ Width $80^{\prime}$ Photo Roll No.

CONSTRUCTION DATA

Rooframing: $Z$-purling + metal deck Intermediate floor framing:

Ground floor: Concrete Basement: None

Exterior walls: Masonry Openings:

Columns: Steel Foundations: Spread footing + Wall tooting

General condition of structure: Very flood

Evidence of settling.

None

LATERAL FORCE RESISTING SYSTEM

Transverse

Model building type:

Building period, $T$ :

Unreduced base shear,

$$
V=\left[\left(0.80 A_{v} \times S\right) /\left(R \times T^{2 / 3}\right)\right] \times(W) \text { or } V=[2.12 \mathrm{Aa} / R] \times W
$$

Response Modification Coefficient, $R: \quad 45$

EVALUATION DATA

$A_{a}=0.05 \quad A_{v}=0.05$

Site soil profile type: $S_{1}$ Site soil coefficient, $S=1.0$

REMARKS

Pre-enqinered steel rigid frames.

Bldg designed for $90 \mathrm{mph}$ wind load. 


\section{EVALUATION STATEMENTS FOR BUILDING TYPE 5: STEEL LIGHT FRAME}

These buildings are pre-engineered and pre-fabricated with transverse rigid frames. The roof and walls consist of light-weight panels. The frames are designed for maximum efficiency, ofien with tapered beam and column sections built up of light plates. The frames are built in segments and assembled in the field with bolted joints. Lateral loads in the transverse direction are resisted by the rigid frames, with loads distributed to them by shear elements. Loads in the longitudinal direction are resisted entirely by shear elements. The shear elements can be either the roof and wall sheathing panels, an independent system of cension-onty rad bracing, or a combination of panels and bracing.

Address the following evaluation statements, marking each either true (T) or false $(F)$. Statements that are found to be true identify issues that are acceptable according to the criteria of this handbook; statements that are found to be faise identify issues that need investigation. For guidance in the investigation, refer to the handbook section indicated in parentheses at the end of the statement.

Be advised that the numerical indices preceded by an asterisk $\left({ }^{*}\right)$ in these statements are based on high seismicity $\left(A_{v}=0.4\right)$. Adjustments are reasonable for lower seismicity. The appropriate adjustment is not necessarily a direct ratio of seismicity.

\section{BUILDING SYSTEMS}

(T) F LOAD PATH: The structure contains a complete load path for seismic force effects from any horizontal direction that serves to transfer the inertial forces from the mass to the foundation (NOTE: Write a brief description of this linkage for each principal direction.) (Sec. 3.1)

(T) F REDUNDANCY: The structure will remain laterally stable after the failure of any single element. (Sec. 3.2)

(T) F WEAK STORY: Visual observation or a Quick Check indicates that there are no significant strength discontinuities in any of the vertical elements in the lateral-forceresisting system; the story strength at any story is not less than 80 percent of the strength of the story above. (Sec. 3.3.1)

(T) F SOFT STORY: Visual observation or a Quick Check indicates that there are no significant stiffness discontinuities in any of the vertical elements in the lateral-forceresisting system; the lateral stiffness of a story is not less than 70 percent of that in the story above or less than 80 percent of the average stiffness of the three stories above. (Sec. 3.3.2)

(T) F TORSION: The lateral force resisting elements form a well balanced system that is not subject to significant torsion. Significant torsion will be taken as any condition where the distance between the story center of rigidity and the story center of mass is greater than 20 percent of the width of the structure in either major plan dimension. (Sec. 3.3.6) 
(T) F DETERIORATION OF STEEL: There is no significant visible rusting, corrosion, or other deterioration in any of the steel elements in the vertical or lateral-force-resisting systems. (Sec. 3.5.3)

\section{MOMENT FRAMES}

(T) F STRESS CHECK: The building satisfies the Quick Check of the stress in the diagonals. (Sec. 6.1.1)

(T) F BEAM PENETRATIONS: All openings in frame-beam webs bave a depth less that $1 / 4$ of the beam depth and are located in the center half of the beams. (Sec. 4.2.3)

\section{DLAPHRAGMS}

(T) F PLAN IRREGULARITTES: There is significant tensile capacity at re-entrant corners or other locations of plan irregularities. (Sec. 7.1.1)

(T) F REINFORCING AT OPENINGS: There is reinforcing around all diaphragm openings larger than 50 percent of the building width in either major plan dimension. (Sec. 7.1.3)

\section{CONNECTIONS}

(T) F STEEL COLUMNS: The columns in the lateral-force-resisting system are substantially anchored to the building foundation. (Sec. 8.4.1)

\section{WALL AND ROOF PANELS}

(T) F LIGHT-GAGE METAL, PLASTIC, OR CEMENTITIOUS ROOF PANELS: All lightgage metal, plastic, or cementitious roof panels are properly connected to the roof framing at not more than 12 inches on center. (Sec. 8.6.1)

(T) F WALL PANELS: All wall panels (metal, fiberglass, or cement asbestos) are properly connected to the framing. (Sec. 8.6.2) 


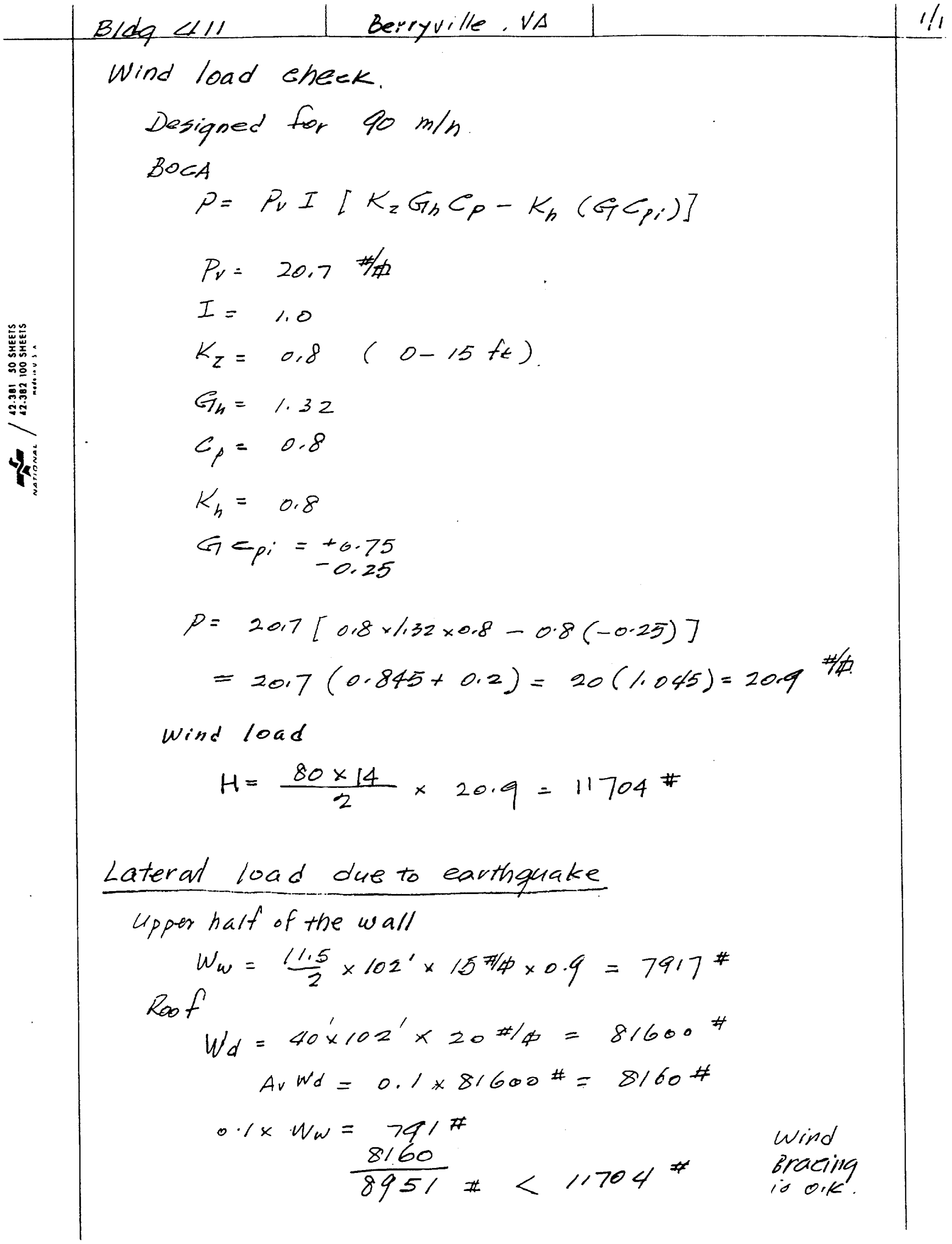




\section{OPTION 2 COST ESTIMATION FORM}

\section{COST ESTIMATION OPTION 2}

1. GROUP MEAN COST

- Group:

$\begin{array}{llll}\square & \text { URM } & \square & \text { s1 } \\ \square & \text { W1.W2 } & \text { s2, s\$3 } \\ \square & \text { PC1.RM1 } & \square & \text { s5 } \\ \square & \text { C1.C3 } & \square & \text { C2,PC2, RM2, S4 }\end{array}$

- Cost Coefficient $C_{1}$ from Table 4.3.2.

$c_{1}=7.23$

2. AREA ADJUSTMENT FACTOR

- Area

Less than 10K sq. ft. $\square 10 K-50 K$ sq. ft.

$\square$ 50K - 100K sq. tt. $\square 10 \mathrm{~K}-50 \mathrm{~K}$ sq. ft.

- Cost Adjustment Factor $C_{2}$ from Table 4.3.3

$c_{2}=1.18$

3. SEISMICITYIPERFORMANCE OBJECTIVE FACTOR ADJUSTMENT

- SEISMICITY

Low (NEHRP 1 or 2) $\square$ Moderate (NEHRP 3 or 4)

$\square$ High (NEHRP 5 or 6 ) $\square$ VerY High (NEHRP 7)

- PERformance obJective

Life Safety $\square$ Damage Control $\square$ Immediate Occupancy

- Cost Adjustment Factor $C_{j}$ from Table 4.4.2

$c_{3}=0.61$

4. LOCATION ADJUSTMENT FACTOR

- City / Stato Berryuille, VA

- Cost Adjustment Factor $c_{t}$ from Table 4.3.4 or Table 4.3.5 $c_{2}=0.84$

5. TIME ADJUSTMENT FACTOR

- Year 1998

- Inflation Rate 2

- Cost Adjustment Factor $C_{Y}$ from Table 4.3.6

$c_{T}=$

$1 \cdot 10$

TYPICAL STRUCTURAL COST

( $\left.C=C_{1} \times C_{2} \times C_{3} \times C_{1} \times C_{4}\right)$

$c=4.81$

Building Area (Square Foot): $\quad A=8816$

Estimated Structural Cost $(A \times C)$

$C_{s}=42,405$

Non-Structural Cost $\left(C_{1} \times C_{L} \times C_{T}\right)$

Finishing Cost (estimated)

$\mathrm{C}_{\mathrm{NS}}=0$

Total (Structural + Non-Struc + Finishing)

$C_{F}=5,000$

Project Cost $\left(C_{S T} \times 0.3\right)$

$C_{S T}=47.405$

Total Cost

$C_{p}=14,221$

$\approx 61,600$ 
Building Designation :

420

Location: Berryuille, VA

DATA SUMMARY SHEET

BUILDING DATA

Year built: $\frac{1955}{\text { Years) remodelled: }--}$
Date of Evaluation: $8 / 5 / 98$
Area, (sq. f.) $7567 \quad$ Length $\quad 122 \quad$ Width $62 \quad$ Photo Roll No.

CONSTRUCTION DATA

Rooframing: Steel Joists

Intermediate floor framing:

Ground flor: None Basement: Nave

Exterior walls: Cone. thasonry openings:

General condition of structure: Very Good

Evidence of settling:

None

LATERAL FORCE RESISTING SYSTEM

Transverse Longitudinal

Model building type:

Building period, $T$ :

Unreduced base shear,

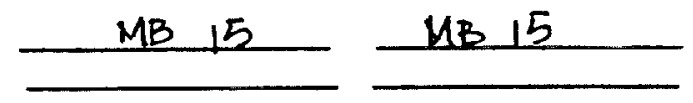

$V=\left[\left(0.80 A_{v} \times S\right) /\left(R \times T^{2 / 3}\right)\right] \times(W)$ or $V=[2.12 A a / R] \times W$

Response Modification Coefficient, $R: \quad 1.5$

EVALUATION DATA

$A_{a}=0.05 \quad A_{v}=0.05$

Site soil profile type: $S_{2}$ Site soil coefficient, $S=1.2$

REMARKS

Soil : wexthren rock, clay silt mixture

Rent. conc. bond breams at the top and mid levels.

Fire station 
(T) F GEOMETRY: There are no significant geometrical irregularities; there are no setbacks (i.e., no changes in horizontal dimension of the lateral-force-resisting system of more than 30 percent in a story relative to the adjacent stories). (Sec. 3.3.3)

(T) F MASS: There are no significant mass irregularities; there is no change of effective mass of more than 50 percent from one story to the nexd, excluding light roofs. (Sec. 3.3.4)

(T) F VERTICAL DISCONTINUITIES: All she?r walls are continuous to the foundation. (Sec. 3.3.5)

(T) F TORSION: The lateral force resisting elements form a well balanced system that is not subject to significant torsion. Significant torsion will be taken as any condition where the distance between the story center of rigidity and the story center of mass is greater than 20 percent of the width of the structure in either major plan dimension. (Sec. 3.3.6)

(T) F ADJACENT BUILDINGS: There is no immediately adjacent structure that is less than half as tall or has floors/levels that do not match those of the building being evaluated. A neighboring structure is considered to be "immediately adjacent" if it is within 2 inches times the number of stories away from the building being evaluated. (Sec. 3.4)

(T) F MASONRY UNITS: There is no visible deterioration of large areas of masonry units. (Sec. 3.5.10)

(T) F MASONRY JOINTS: The mortar cannot be easily scraped away from the joints by hand with a metal tool, and there are no significant areas of eroded mortar. (Sec. 3.5.9)

For buildings with wood diaphragms and unreinforced masonry bearing and enclosure walls at the perimeter, complete the evaluation using the procedure given in Appendix C. For other buildings, continue with the following evaluation statements.

\section{MASONRY WALLS}

(T) F SHEARING STRESS CHECK: The building satisfies the Quick Check of the shearing stress in the unreinforced masonry shear walls. (Sec. 5.4.1)

(T) F PROPORTIONS: In areas of high seismicity $\left(A_{v}\right.$ greater than or equal to 0.2$)$, the heightthickness ratio of the unreinforced masonry wall panels is as follows: (Sec. 5.5.1; also see Appendix C)

- One-story building:

- Multistory building:

Top story:

Other stories:

$$
\begin{aligned}
& h_{\text {Hor }} / t<14 \\
& h_{\mu r} / t<9 \\
& h_{H_{N}} / t<20
\end{aligned}
$$

(T) F MASONRY LAY-UP: Filled collar joints of multiwythe masonry walls have negligible voids. (Sec. 5.4.2) 


\section{DIAPHRAGMS}

(T) F PLAN IRREGULARITIES: There is significant tensile capacity at re-entrant corners or other locations of plan irregularities. (Sec. 7.1.1)

(T) F REINFORÇING AT OPENINGS: There is reinforcing around all diaphragm openings larger than 50 percent of the building width in either major plan dimension. (Sec. 7.1.3)

(T) F SPAN/DEPTH RATIO: If the span/depth ratios of wood diaphragms are greater than 3 to 1 , there are nonstructural walls connected to all diaphragm levels at less than 40 -foot spacing. (Sec. 7.2.4)

(T) F SHEATHING: None of the diaphragms consist of straight sheathing or have span/depth ratios greater than 2 to 1 . (Sec. 7.2.1)

\section{CONNECTIONS}

(T) F MASONRY WALL ANCHORS: Wall anchorage connections are steel anchors or straps that are developed into the diaphragm. (Sec. 8.2.3)

(T) F ANCHOR SPACING: The anchors from the floor and roof systems into exterior masonry walls are spaced at 4 feet or less. (Sec. 8.2.4) 
Building Designation : 431

Location: Berryville, VA

\section{DATA SUMMARY SHEET}

\section{BUILDING DATA}

Year built: 1974

Date of Evaluation: $8 / 5 / 98$

Area, (sq. ft.) 16330 Leagth 160 Width 102 Photo Roll No.

\section{CONSTRUCTION DATA}

Rooframing. steel joists, metal deck

Intermediatefloorframing: None

Ground floor: CoNe Basement:

Exterior walls: Masenry Openings:

Columns. Tubular stoel th Foundations: Cone wall t spread t+q.

General condition of structure:

Evidence of settling: None

\section{LATERAL FORCE RESISTING SYSTEM}

\section{Transverse Longitudinal}

Model building type:

Building period, $T$ :

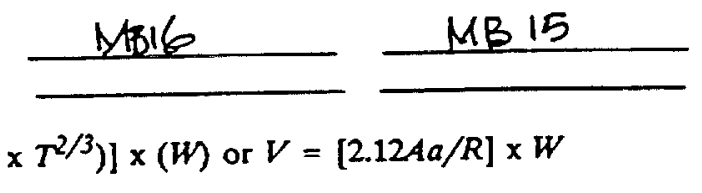

$V=\left[\left(0.80 A_{v} \times S\right) /\left(R \times T^{2 / 3}\right)\right] \times(W)$ or $V=[2.12 A a / R] \times W$

Response Modification Coefficient, $R$ : 1.5

\section{EVALUATION DATA}

$A_{a}=0.05 \quad A_{v}=0.05$

Site soil profile type: $S \mid$ Site soil coefficient, $S=1.0$

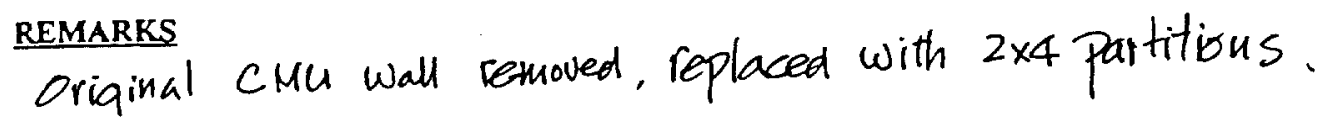


Bidq. 431 , Berryuille, $V_{A}$

\section{EVALUATION STATEMENTS FOR BUILDING TYPE 15: UNREINFORCED MASONRY BEARING WALL BUILDINGS}

These buildings include structural elements that vary depending on the age of the building and, to a lesser extent, the geographic location of the structure. In buildings built before 1900, the majority of floor and roof construction consists of wood sheathing supported by wood subframing. In lange multistory buildings, the floors are cast-in-place concrete supponed by the unreinfonced masonry walls and/or steel or concrete interior framing. In buildings built afier 1950, unreinforced masonry buildings with wood floors usually have phwood rather than board sheathing. More recently, in regions of lower seismicity, these buildings can include floor and roof framing that consists of metal deck and concrete fill supponed by steel froming elements. The perimeter walls, and possibly some interior walls, are unreinforced masonry. The walls may or may not be anchored to the diaphragms. Ties between the walls and diaphragms are more common for the bearing walls than for walls that are parallel to the floor framing. Roof ties usually are less common and more erratically spaced than those at the floor levels. Interior partitions that interconnect the floors and roof can have the effect of reducing diaphragm displacements.

Address the following evaluation statements, marking each either true (T) or false (F). Statements that are found to be true identify issues that are acceptable according to the criteria of this handbook; statements that are found to be false identify issues that need investigation. For guidance in the investigation, refer to the handbook section indicated in parentheses at the end of the statement.

Be advised that the numerical indices preceded by an asterisk ( $\left.{ }^{*}\right)$ in these statements are based on high seismicity $\left(A_{v}=0.4\right)$. Adjustments are reasonable for lower seismicity. The appropriate adjustment is not necessarily a direct ratio of seismicity.

\section{BUILDING SYSTEMS}

T (F)

LOAD PATH: The structure contains a complete load path for seismic force effects from any horizontal direction that serves to transfer the inertial forces from the mass to the foundation (NOTE: Write a brief description of this linkage for each principal direction.) (Sec. 3.1)

(T) F REDUNDANCY: The structure will remain laterally stable after the failure of any single element. (Sec. 3.2)

(T) F WEAK STORY: Visual observation or a Quick Check indicates that there are no significant strength discontinuities in any of the vertical elements in the lateral-forceresisting system; the story strength at any story is not less than 80 percent of the strength of the story above. (Sec. 3.3.1) one-story struct.

(T) F SOFT STORY: Visual observation or a Quick Check indicates that there are no significant stiffness discontinuities in any of the vertical elements in the lateral-forceresisting system; the lateral stiffness of a story is not less than 70 percent of that in the story above or less than 80 percent of the average stiffness of the three stories above. (Sec. 3.3.2)

$$
\text { one-story struct. }
$$


(T) F GEOMETRY: There are no significant geometrical irregularities; there are no setbacks (i.e., no changes in horizontal dimension of the lateral-force-resisting system of more than 30 percent in a story relative to the adjacent stories). (Sec. 33.3)

(T) F MASS: There are no significant mass irregularities; there is no change of effective mass of more than 50 percent from one story to the next, excluding light roofs. (Sec. 3.3.4)

(T) F VERTICAL DISCONTINUITIES: All shear walls are continuous to the foundation. (Sec. 3.3.5)

(T) F TORSION: The lateral force resisting elements form a well balanced system that is not subject to significant torsion. Significant torsion will be taken as any condition where the distance between the story center of rigidity and the story center of mass is greater than 20 percent of the width of the structure in either major plan dimension. (Sec. 3.3.6)

(T) F ADJACENT BUILDINGS: There is no immediately adjacent structure that is less than half as tall or has floors/levels that do not match those of the building being evaluated. A neighboring structure is considered to be "immediately adjacent" if it is within 2 inches times the number of stories away from the building being evaluated. (Sec. 3.4)

(T) FASONRY UNTTS: There is no visible deterioration of large areas of masonry units. (Sec. 3.5.10)

(T) F MASONRY JOINTS: The mortar cannot be easily scraped away from the joints by hand with a metal tool, and there are no significant areas of eroded mortar. (Sec. 3.5.9)

For buildings with wood diaphragms and unreinforced masonry bearing and enclosure walls at the perimeter, complete the evaluation using the procedure given in Appendix C. For other buildings, continue with the following evaluation statements.

\section{MASONRY WALLS}

(T) F SHEARING STRESS CHECK: The building satisfies the Quick Check of the shearing stress in the unreinforced masonry shear walls. (Sec. 5.4.1)

(T) F PROPORTIONS: In areas of high seismicity $\left(A_{v}\right.$ greater than or equal to 0.2$)$, the heightthickness ratio of the uareinforced masonry wall panels is as follows: (Sec. 5.5.1; also see Appendix C)

- One-story building:

- Multistory building:

Top story: Other stories:

$$
\begin{aligned}
& h_{\omega} / t<14 \quad \frac{114}{8}=14.25 \quad 0.6 . \\
& h_{\kappa N} / t<9 \\
& h_{\omega} / t<20
\end{aligned}
$$

(T) F MASONRY LAY-UP: Filled collar joints of multiwythe masonry walls have negligible voids. (Sec. 5.4.2) N/A 


\section{DIAPHRAGMS}

(T) F PLAN IRREGULARITIES: There is significant tensile capacity at re-entrant corners or other locations of plan irregularities. (Sec. 7.1.1) N/A

(T) F REINFORCING AT OPENINGS: There is reinforcing around all diaphragm openings larger than 50 percent of the building width in either major plan dimension. (Sec. 7.1.3) NA

(T) F SPAN/DEPTH RATIO: If the span/depth ratios of wood diaphragms are greater than 3 to 1 , there are nonstructural walls connected to all diaphragm levels at less than 40 -foot spacing. (Sec. 7.2.4) $\frac{140}{60}=2.3$

(T) F SHEATHING: None of the diaphragms consist of straight sheathing or have span/depth ratios greater than 2 to 1 . (Sec. 7.2.1)

\section{CONNECTIONS}

(T) F MASONRY WALL ANCHORS: Wall anchorage connections are steel anchors or straps that are developed into the diaphragm. (Sec. 8.2.3)

T F ANCHOR SPACING: The anchors from the floor and roof systems into exterior masonry walls are spaced at 4 feet or less. (Sec. 8.2.4) 
Bldg 431 Berryuille. VA

$1 / 2$

check square tubular column strength

column size: $6 \times 6 \times 1 / 4$

it eel: $A 36$

Length of col: $12^{\prime}-6^{\prime \prime}$

Tributary area

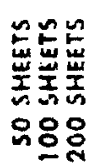

for each col.: $20^{1} \times 201$.

- Assume no moment is transferred from steel joists or $I$ purling to the top of column.

- Lateral load is applied to the top of column.

Load: Roof 10 psf

snow $\frac{30 \mathrm{psf}}{\text { to psf }}$

Vertical load on col.

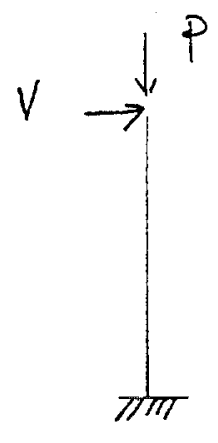

$$
40 \times 20^{\circ} \times 20^{\prime}=16,000^{\mathrm{k}} \text { or } 16 \mathrm{~K}
$$

Assume $T=0.1 \mathrm{sec}$.

$$
\begin{aligned}
& c_{s}=\frac{2.12 A_{a}}{R}=\frac{2.12 \times 0.05}{2}=0.053 \\
& v=C_{s} w=0.053 \times 16=0.85 \mathrm{k}
\end{aligned}
$$

Bending $M=0.85 \times 150^{\prime \prime}=127.5 \mathrm{k}-$ in

$$
\begin{aligned}
& P=16 \mathrm{~K} \\
& K L=2 L \\
& \frac{k L}{r}=\frac{2.0 \times 150}{2.33}=129
\end{aligned}
$$


Bida 431

Berryuille VA

$2 / 2$

$$
\begin{aligned}
& c_{c}=\sqrt{\frac{2 \pi^{2} E}{F_{y}}}=\sqrt{\frac{2 \pi^{2} 29000}{36}}=126.1 \\
& \frac{k L}{r}>c_{c} \quad F_{a}=\frac{12 \pi^{2} E}{23\left(\frac{k L}{r}\right)^{2}}=9 \mathrm{ksi} \\
& F_{b}=0.66 F_{y}=24 \mathrm{ksi} \\
& F_{e}^{\prime}=\frac{12 \pi^{2} E}{23\left(\frac{k L}{r}\right)^{2}}=9 \mathrm{ksi} \\
& f_{a}=\frac{P}{A_{q}}=\frac{16}{5.59}=2.86 \mathrm{ksi} \\
& f_{b}=\frac{M}{3}=\frac{127.5}{10.1}=12.62 \mathrm{ksi} \\
& C_{m}=0.85 \\
& \frac{f_{a}}{F_{a}}+\frac{C_{m} f_{b}}{\left(1-\frac{f_{a}}{F_{a}}\right) F_{b}}=\frac{2.86}{q}+\frac{0.85 \times 12.62}{\left(1-\frac{2.86}{q}\right) \times 24} \\
& =0.318+0.655=0.973<1.0
\end{aligned}
$$

Marginally $0 . \mathrm{K}$ 
Building Designation :

704

Location:

Berryulle, VA

DATA SUMMARY SHEET

BUILDING DATA

Year built: 1956 Years) remodelled:

Date of Evaluation: $8 / 5 / 98$

Area, (sq. ft.) $198 \overline{92}$ Length $180^{\prime}$ Width $28^{\prime}$ Photo Roll No.

CONSTRUCTION DATA

Rooframing: $2 \times 8$ wood ratters 24" oc Intermediatefloorframing: $2 \times 8$ wood joists e 16 " oC Ground floor: $2 \times 8$ Wood JoisBasement: Partial / Concrete Exterior walls: emu Openings: windows Columns: Steal Pipes Foundations: Cenacle spread tooting

Evidence of settling: None

LATERAL FORCE RESISTING SYSTEM

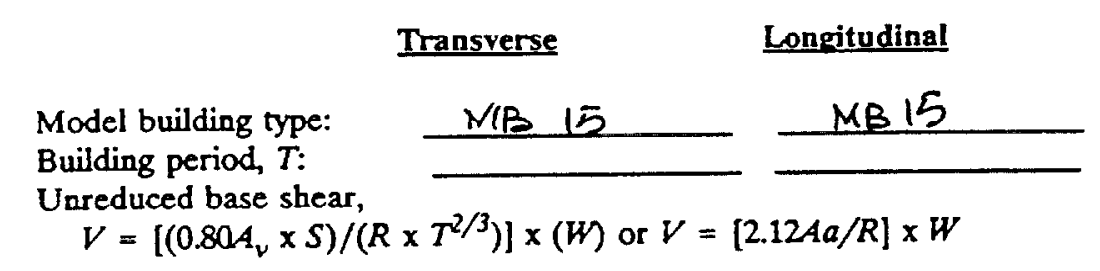

Response Modification Coefficient, $R$ : 1.5

EVALUATION DATA

$A_{a}=\underline{0.05} \quad A_{v}=\underline{0.05}$

Site soil profile type: $S_{2}$ Site soil coefficient, $s=1.2$

REMARKS 


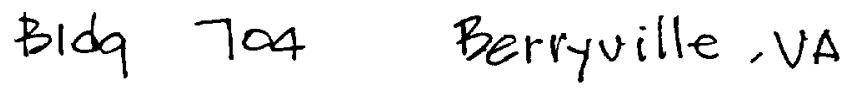

\section{EVALUATION STATEMENTS FOR BUILDING TYPE 15: UNREINFORCED MASONRY BEARING WALL BUILDINGS}

These buildings include structural elements that vary depending on the age of the building and, to a lesser extent, the geographic location of the structure. In buildings built before 1900, the majority of floor and roof construction consists of wood sheathing supponed by wood subframing. In large multistory buildings, the floors are cast-in-place concrete supported by the unreinfonced masonry walls and/or steel or concrete interior framing. In buildings built after 1950, unreinforced masonry buildings with wood floors usually have phwood rather than board sheathing. More recently, in regions of lower seismicity, these buildings can include floor and roof framing that consists of metal deck and concrete fill supported by steel framing elements. The perimeter walls, and possibly some interior walls, are unreinforced masonry. The walls may or may not be anchored to the diaphragms. Ties between the walls and diaphragms are more common for the bearing walls than for walls that are parallel to the floor framing. Roof ties usually are less common and more erratically spaced than those at the floor levels. Interior partitions that interconnect the floors and roof can have the effect of reducing diaphragm displacements.

Address the following evaluation statements, marking each either true ( $T$ ) or false (F). Statements that are found to be true identify issues that are acceptable according to the criteria of this handbook; statements that are found to be false identify issues that need investigation. For guidance in the investigation, refer to the handbook section indicated in parentheses at the end of the statement.

Be advised that the numerical indices preceded by an asterisk $\left(^{*}\right)$ in these statements are based on high seismicity $\left(A_{v}=0.4\right)$. Adjustments are reasonable for lower seismicity. The appropriate adjustment is not necessarily a direct ratio of seismicity.

\section{BUILDING SYSTEMS}

LOAD PATH: The structure contains a complete load path for seismic force effects from any horizontal direction that serves to transfer the inertial forces from the mass to the foundation (NOTE: Write a brief description of this linkage for each principal direction.) (Sec. 3.1)

T F REDUNDANCY: The structure will remain laterally stable after the failure of any single element. (Sec. 3.2)

(T) F WEAK STORY: Visual observation or a Quick Check indicates that there are no significant strength discontinuities in any of the vertical elements in the lateral-forceresisting system; the story strength at any story is not less than 80 percent of the strength of the story above. (Sec. 3.3.1)

(T) F SOFT STORY: Visual observation or a Quick Check indicates that there are no significant stiffness discontinuities in any of the vertical elements in the lateral-forceresisting system; the lateral stiffness of a story is not less than 70 percent of that in the story above or less than 80 percent of the average stiffness of the three stories above. (Sec. 3.3.2) 
(T) F GEOMETRY: There are no significant geometrical irregularities; there are no setbacks (i.e., no changes in horizontal dimension of the lateral-force-resisting system of more than 30 percent in a story relative to the adjacent stories). (Sec. 3.3.3)

(T) F MASS: There are no significant mass irregularities; there is no change of effective mass of more than 50 percent from one story to the next, excluding light roofs. (Sec. 3.3.4)

(T) F VERTICAL DISCONTINUITIES: All shear walls are continuous to the foundation. (Sec. 3.3.5)

T F TORSION: The lateral force resisting elements form a well balanced system that is not subject to significant torsion. Significant torsion will be taken as any condition where the distance between the story center of rigidity and the story center of mass is greater than 20 percent of the width of the structure in either major plan dimension. (Sec. 3.3.6)

(T) F ADJACENT BUILDINGS: There is no immediately adjacent structure that is less than half as tall or has floors/levels that do not match those of the building being evaluated. A neighboring structure is considered to be "immediately adjacent" if it is within 2 inches times the number of stories away from the building being evaluated. (Sec. 3.4)

(T) F MASONRY UNITS: There is no visible deterioration of large areas of masonry units. (Sec. 3.5.10)

(T) F MASONRY JOINTS: The mortar cannot be easily scraped away from the joints by hand with a metal tool, and there are no significant areas of eroded mortar. (Sec. 3.5.9)

For buildings with wood diaphragms and unreinforced masonry bearing and enclosure walls at the perimeter, complete the evaluation using the procedure given in Appendix C. For other buildings, continue with the following evaluation statements.

\section{MASONRY WALLS}

(T) F SHEARING STRESS CHECK: The building satisfies the Quick Check of the shearing stress in the unreinforced masonry shear walls. (Sec. 5.4.1)

(T) F PROPORTIONS: In areas of high seismicity ( $A_{v}$ greater than or equal to 0.2$)$, the heightthickness "ratio of the unreinforced masonry wall panels is as follows: (Sec. 5.5.1; also see Appendix C)

- One-story building:

- Multistory building:

Top story.

Other stories:

$$
\begin{aligned}
& h_{w} / t<14 \\
& h_{w} / t<9 \\
& h_{w} / t<20
\end{aligned}
$$

(T) F MASONRY LAY-UP: Filled collar joints of multiwythe masonry walls have negligible voids. (Sec. 5.4.2) 


\section{DIAPHRAGMS}

(T) F PLAN IRREGULARITIES: There is significant tensile capacity at re-entrant corners or other locations of plan irregularities. (Sec. 7.1.1)

(T) F REINFORCING AT OPENINGS: There is reinforcing around all diaphragm openings larger than " 50 percent of the building width in either major plan dimension. (Sec. 7.1.3)

(T) F SPAN/DEPTH RATIO: If the span/depth ratios of wood diaphragms are greater than 3 to 1 , there are nonstructural walls connected to all diaphragm levels at less than 40 -foot spacing. (Sec. 7.2.4)

(T) F SHEATHING: None of the diaphragms consist of straight sheathing or have span/depth ratios greater than 2 to 1 . (Sec. 7.2.1)

\section{CONNECTIONS}

T (F) MASONRY WALL ANCHORS: Wall anchorage connections are steel anchors or straps that are developed into the diaphragm. (Sec. 8.2.3) Not known

T (F) ANCHOR SPACING: The anchors from the floor and roof systems into exterior masonry walls are spaced at 4 feet or less. (Sec. 8.2.4) Not KnowN 
beirprille \#-104.

$8-21-98$

$1 / 9$

Weight of Burlding

Long. Walls

$$
\begin{aligned}
& 180^{\prime} \times 10^{\prime} \times 55=99000 \quad\left(8^{4} \text { hollow c,B }\right) \\
& 180 \times 9.3 \times 80=133920 \quad\left(11^{1 / 2} \text { "hollow } 0.5\right)
\end{aligned}
$$

End walls

$$
\begin{aligned}
& 28 \times 10 \times 55=15400 \\
& 28 \times 9.3 \times 80=20832
\end{aligned}
$$

Partitions

and fe $2^{\text {th }} \times 180 \times 28=10080$

$1^{\text {th }} \mathrm{fl} 2 \times 180 \times 28=10080$

Floor

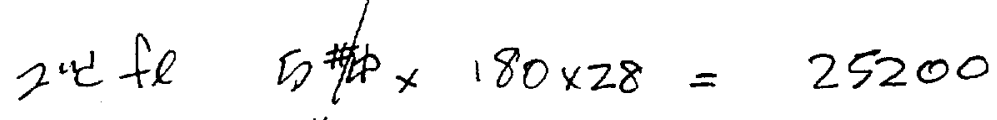

$1^{\text {st }}$ fe 节 $/$ 中 $\times 180 \times 28=25200$

CEILINGS

$$
\begin{aligned}
& 2^{\text {nd }} \text { fe } 1 \times 180428=5040 \\
& 1^{\text {trte }} 1 \times 180 \times 28=5040
\end{aligned}
$$

Roof (werd therses).

$$
\text { eatters + Norsts }
$$

Rooting

$$
5 \times 180428=25200
$$

L.L.

$$
2 \times 180 \times 28=10080
$$

gind fi ouky $50 \times 180 \times 28=\frac{252000}{637,072}$ 


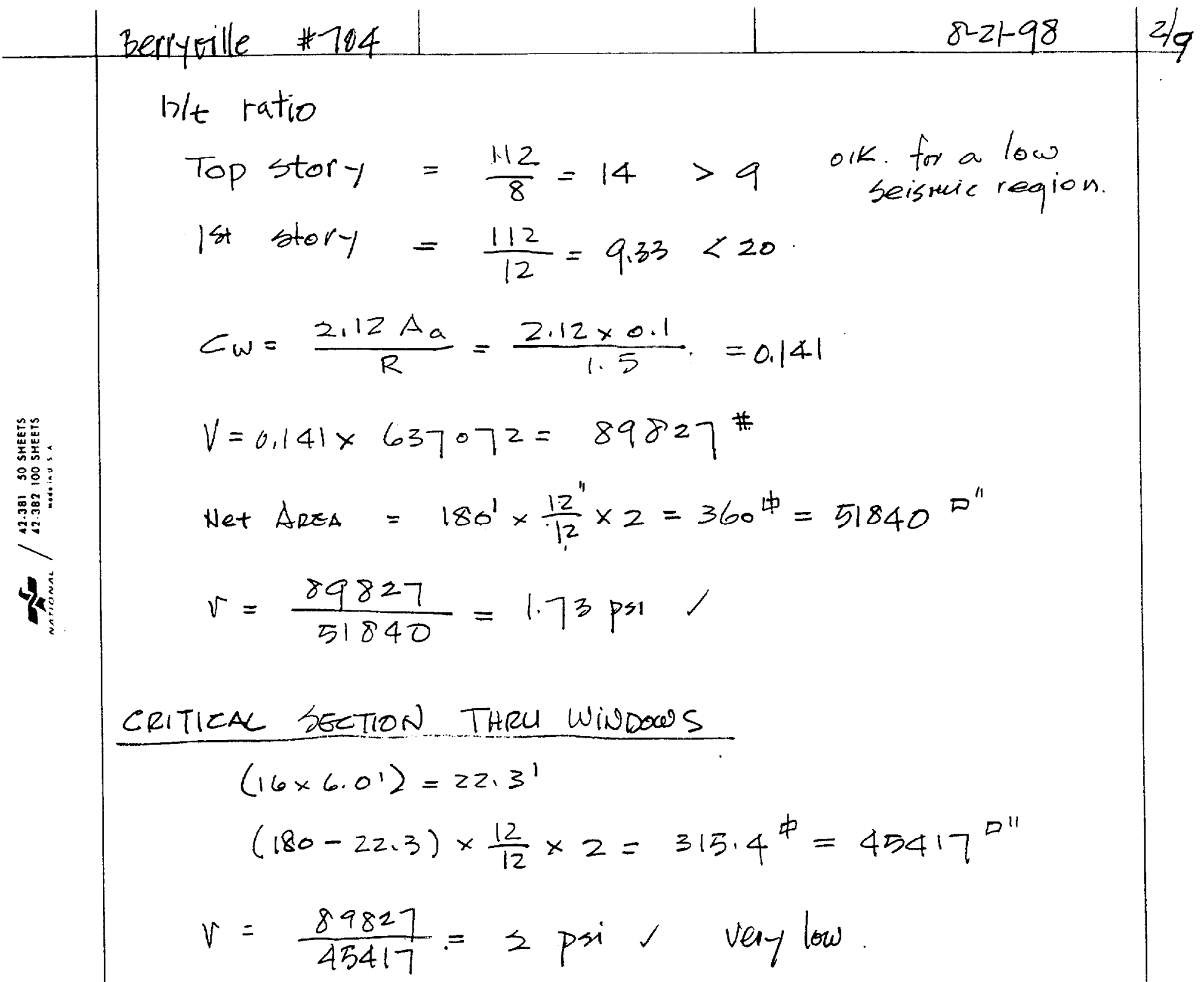

Even w/ snow load acting $V$ would be very low. 
BerRPNILCE \#T04.

$9-21-98$

$3 / 9$

CHEEK Diaphragm A TON at Iud Fl.

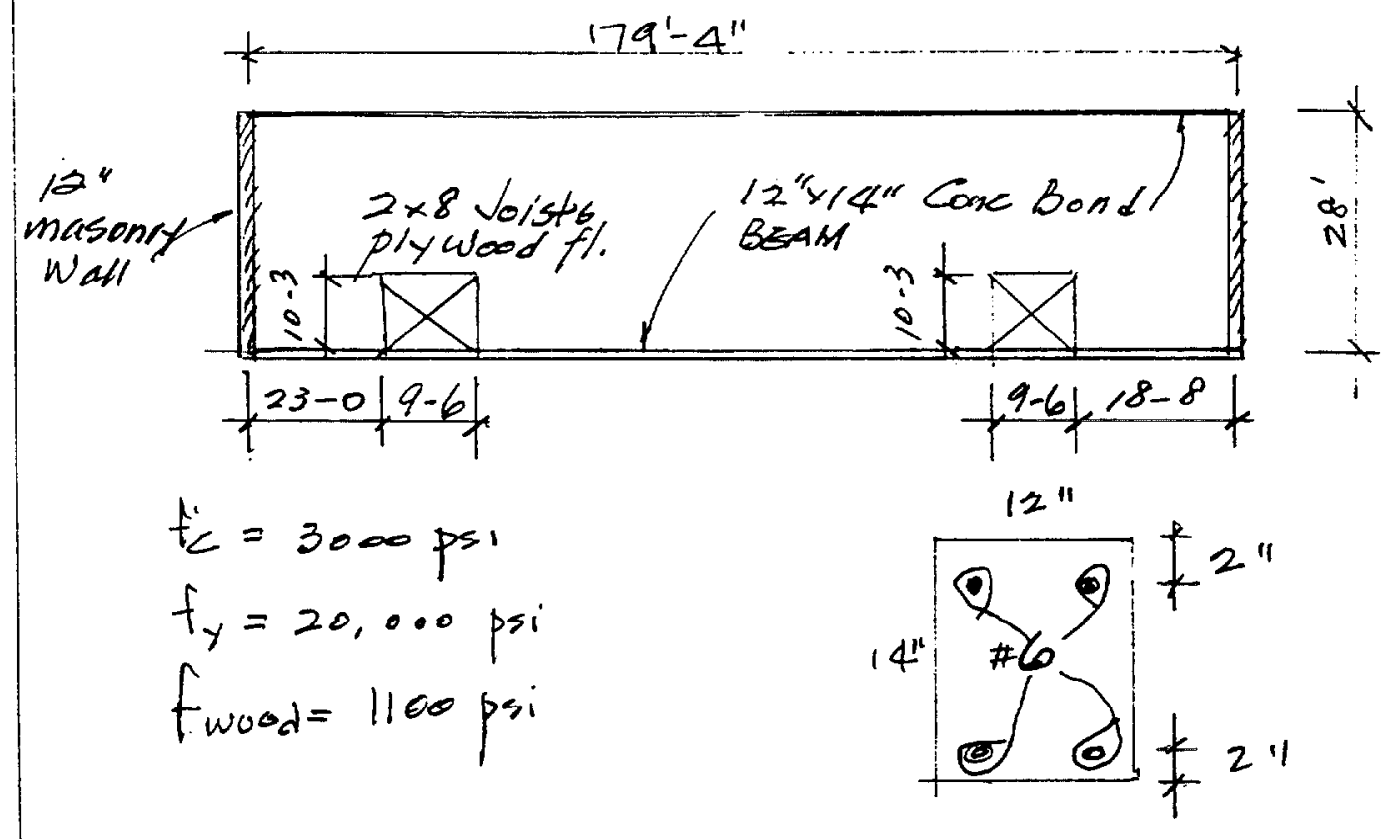

Lateral Load on ChORDS (BOND Beams)

$$
\begin{aligned}
& D L+L L=40320+252000=292,320 \# \\
& D L \text { Floor } 25200 \text { \# } \\
& \text { Partition 10080 \# } \\
& \text { ceiling } \frac{5040}{40320} \\
& \text { LL: } \quad 252000
\end{aligned}
$$

$$
\begin{aligned}
& F_{x}=C_{v x} v \\
& C_{v x}=\frac{w_{x} h_{x}^{k}}{\sum w_{i} h_{i}^{k}}
\end{aligned}
$$

$$
\begin{array}{rlr}
T_{a} & =\frac{0.05 h_{n}}{\sqrt{L}} \quad \begin{array}{l}
L=180^{\prime} \\
h_{n}=20^{\prime}
\end{array} \\
& =\frac{0.0520}{\sqrt{180}}=0.07 \mathrm{tec}
\end{array}
$$

$$
\operatorname{libe}_{162812.2} T=C_{+}\left(h_{n}\right)^{3 / 4}=\underset{9.46}{0.02}(20)^{3 / 4}=0.189 \mathrm{Hec}
$$


DERRAVILLE \#704

$9-21-98$

$4 / 9$

Building Period

USE $0.13 \mathrm{sec}$.

$k=1$

Snow load

$$
\begin{aligned}
& P_{f}=c_{e} I P_{g}=0.7 \times 1.0 \times 25=17.5 \# / 4 \\
& P_{s}=c_{s} P_{f}=\left[1-\frac{(22.6-30)}{40}\right] 17.5=1.185 \times 17.5 \cong 20^{\# / 4}
\end{aligned}
$$

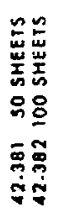

Root level:

$$
\begin{aligned}
& \omega_{R}= 25200 \\
& 10080 \\
& 5040
\end{aligned}
$$

Ind fl level: $29232 \#+99000+15400=143632 \#$

$$
h_{r}=101
$$

$$
\begin{aligned}
c_{4 x} & =\frac{143632(10)^{\prime}}{(40320 \times 20)+(143632 \times 10)}=\frac{.1436320}{2242720} \\
& =0.64
\end{aligned}
$$

$$
\begin{aligned}
& F_{x}=0.64 \times 89827=57528 \\
& f_{x}=\frac{57528}{179.25}=321 \# / f t \\
& M=\frac{321(179.25)^{2}}{8}=1289239^{f-\#}
\end{aligned}
$$

Transformed section of bond beams.

$$
\begin{array}{rlrl}
\# 6=0.44 \mathrm{~m}^{2} & & \\
\sum \text { steel area } & =4 \times 0.44=1.76 & E_{c} & =57000 \sqrt{3000} \\
n=\frac{30}{3.122} & =9.6 & & =3122 \cdot \mathrm{ksi}
\end{array}
$$




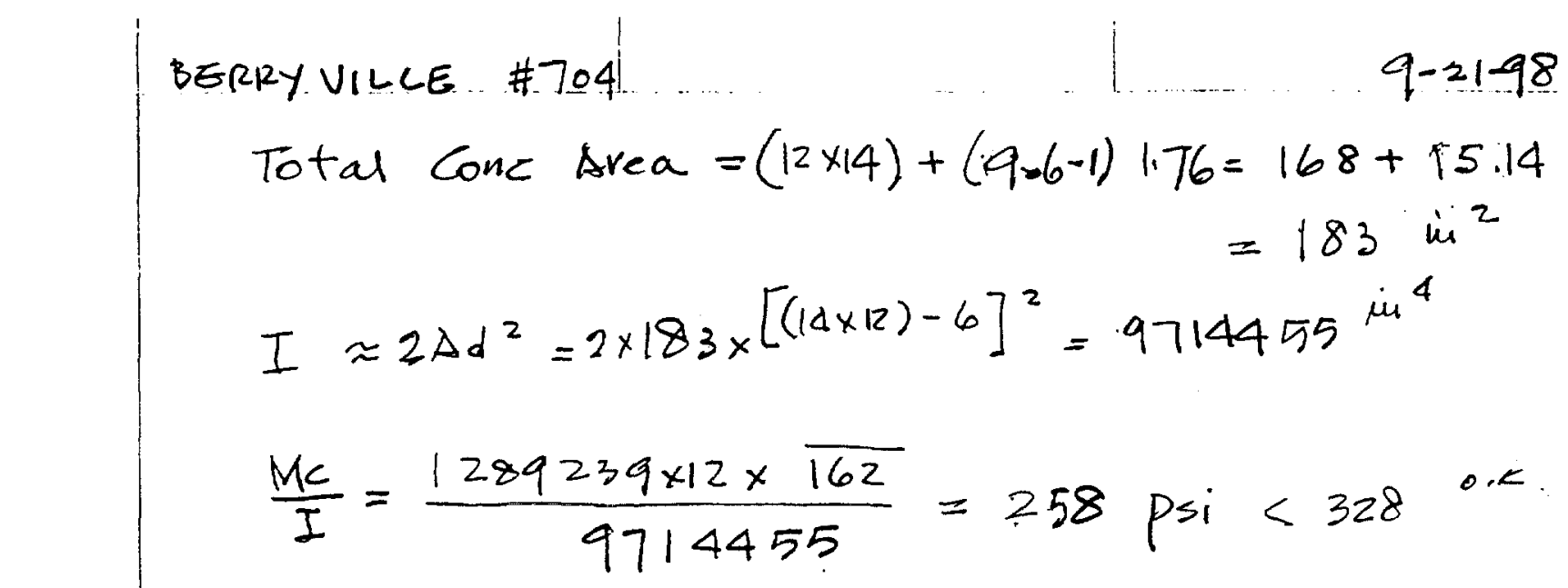

$$
\begin{aligned}
& f_{t}=6 \sqrt{f_{c}^{\prime}}=6 \sqrt{3000}=328 \mathrm{par} \text {. } \\
& \text { Tensile strength of Cove }
\end{aligned}
$$

Buckling Possibility cheek

$$
\begin{aligned}
C & =268 \times 12 \times 14=45024 \\
P & =\frac{\pi^{2} E I}{L^{2}} \\
I= & \frac{b h^{3}}{12}+2 A d^{2}=\frac{14(12)^{3}}{12}+2(183)(4)^{2} \\
& =2016+5856=7872^{\text {m } 4} \\
P & =\frac{(3.14)^{2} 3122000 \times 7872}{(2152)^{2}}=52323^{0 . K}
\end{aligned}
$$

No Buckling.

Char stress in Plywood

$5 / 9$

\$) 


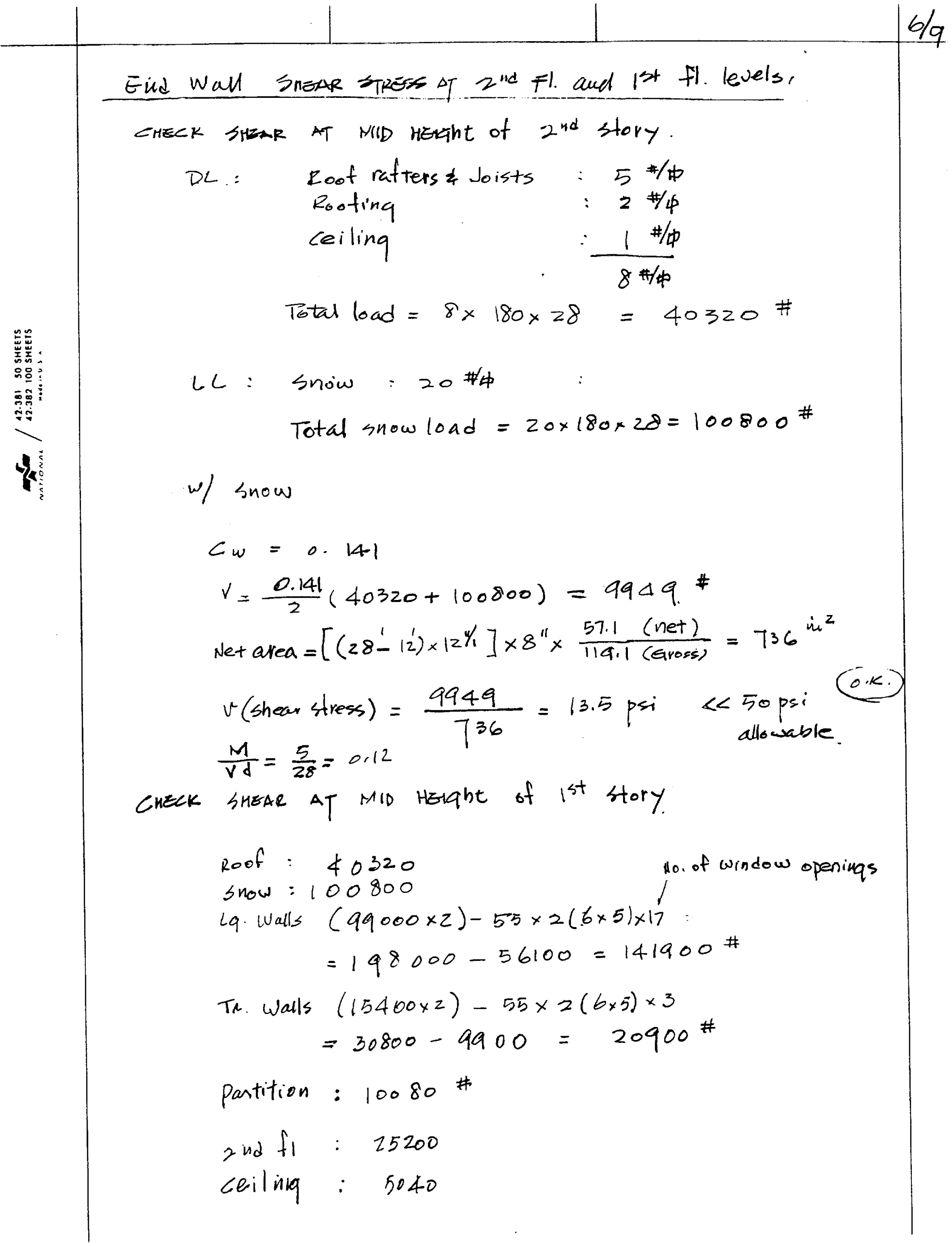




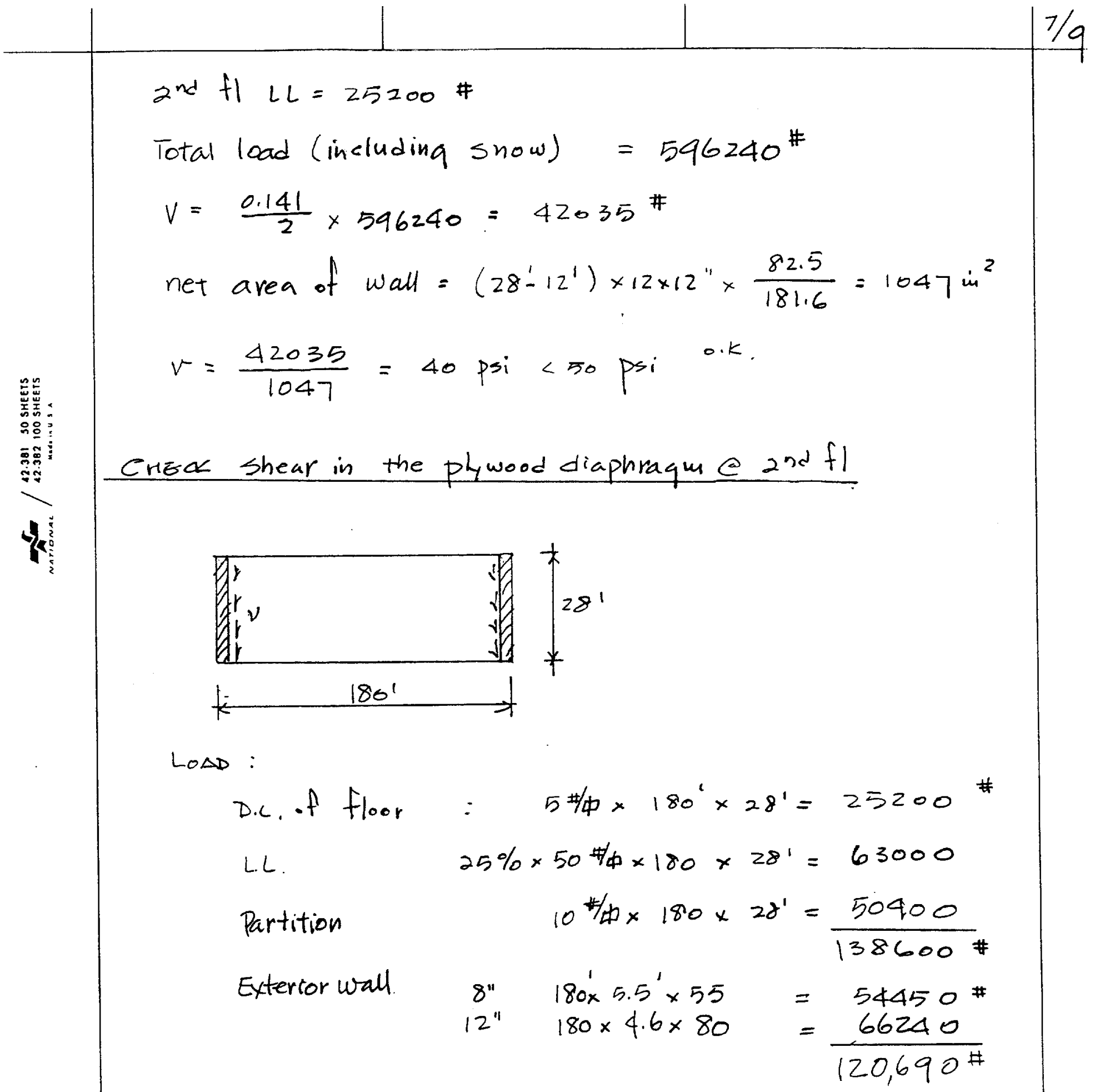

a) Assume all lateral loads are resisted by wood diaphragm U BC 97. $f_{p}=1.0$ CaI $\omega_{p} \quad C_{a}=0.12$ (S Soil, zone 1)

$w_{p}=$ floor la ad + wall load

$$
=138600+(2 \times 120690)=379980
$$

$$
f_{p}=1.0 \times 0.12 \times 1.0 \times 379980=45.600 \#
$$




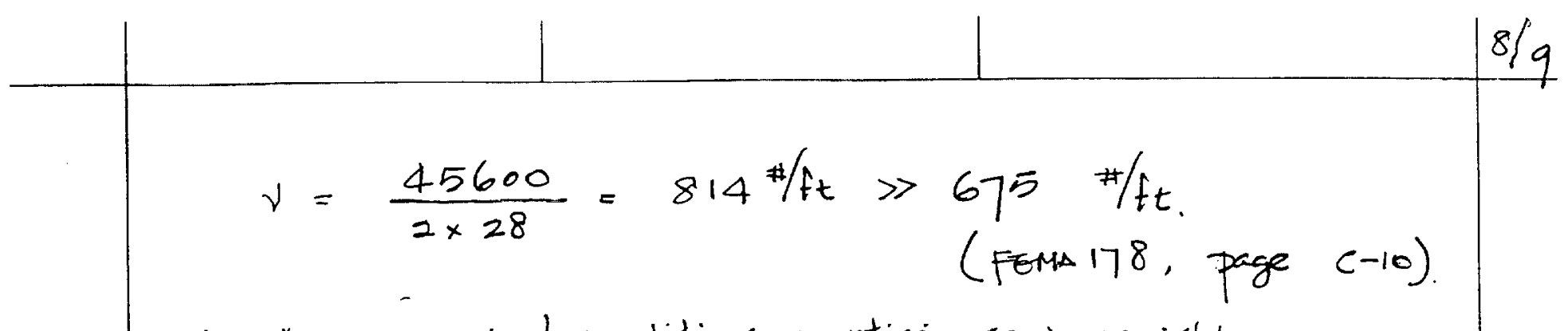

2) Assume wood partitions participate in resisting lateral load by $30 \%$

There are over twenty

$2 \times 4$ Gypum wall partitions in transverse directions $2 \times 4$ plates are nailed to wood joists and to roof ratters.

$$
\begin{aligned}
V & =70 \% \times 814 \\
& =570 \# / f_{t}<67^{5} / f_{t}
\end{aligned}
$$

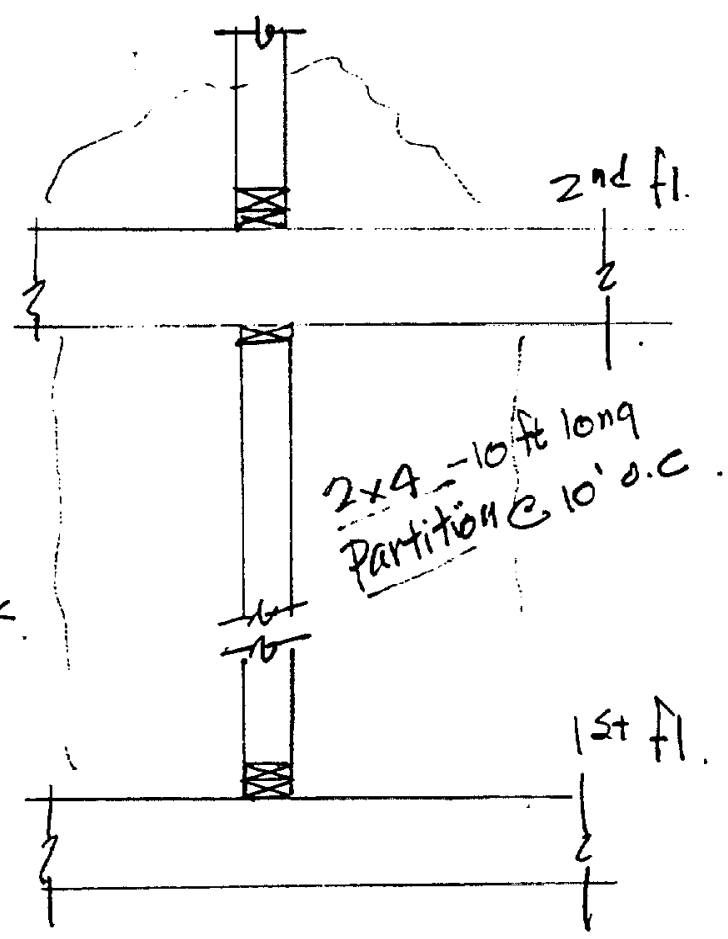

3). CHECK Mid spas Deflection.

(ATC. 7 , page 167 ; FEMA 303) No chord slip.

$$
\begin{aligned}
& \Delta=\frac{5 \nu l^{3}}{8 w E A}+\frac{v l}{4 G t}+0.188 b e_{n}+\frac{\Sigma\left(\not \phi_{c} x\right)}{2 w} \\
& l=180^{\prime} \\
& \omega=28^{\circ} \\
& E_{c}=3,222,000 \text { psi (conc). } \\
& A_{c}=8 \times 14=112 \dot{\mu}^{2} \\
& G=60,000 \text { psi } \\
& e_{n}=0.077 \text { (ssoumed } 100 \text { nail e 3") 240" } \\
& t=3 / 4 "
\end{aligned}
$$




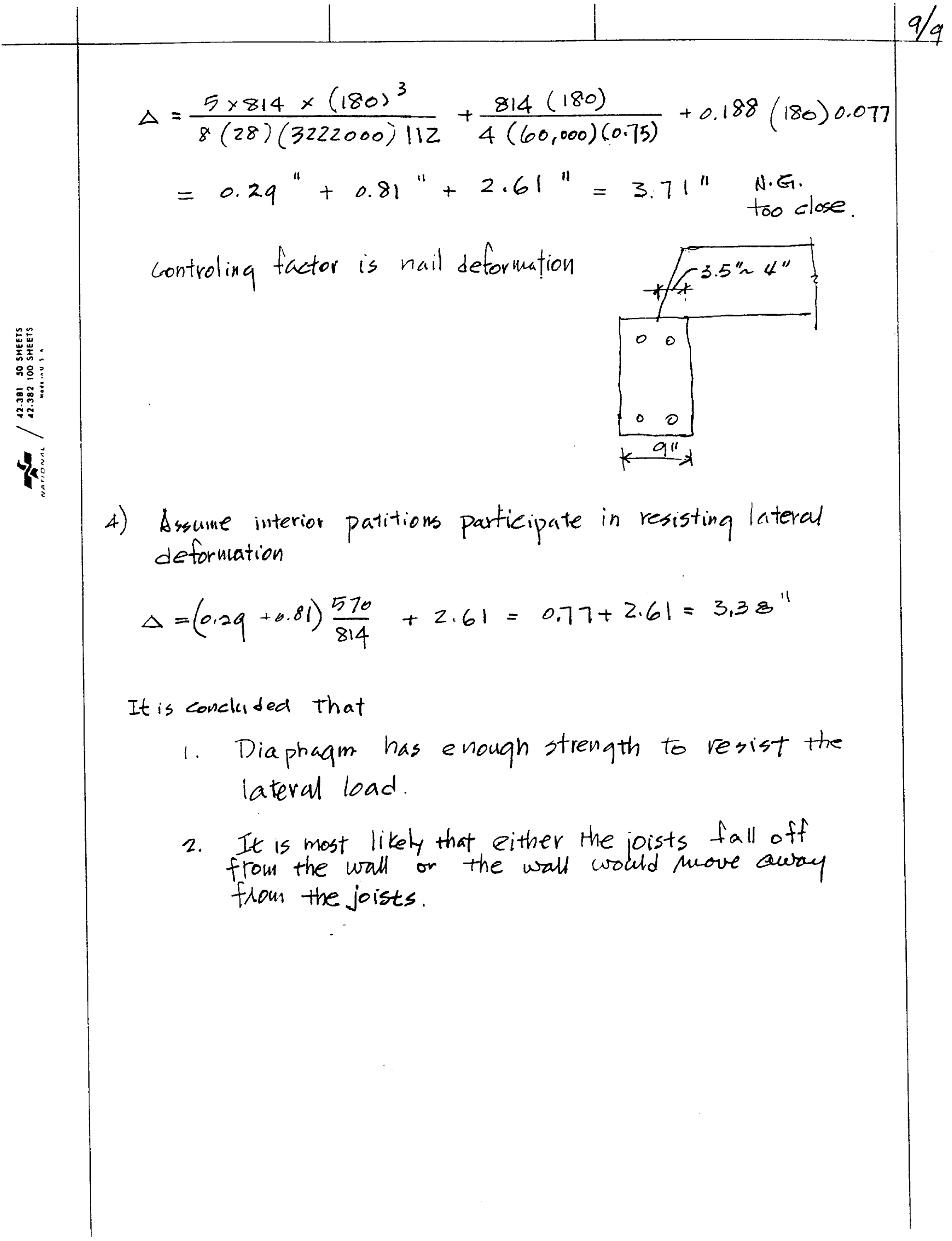


OPTION 2 COST ESTIMATION FORM

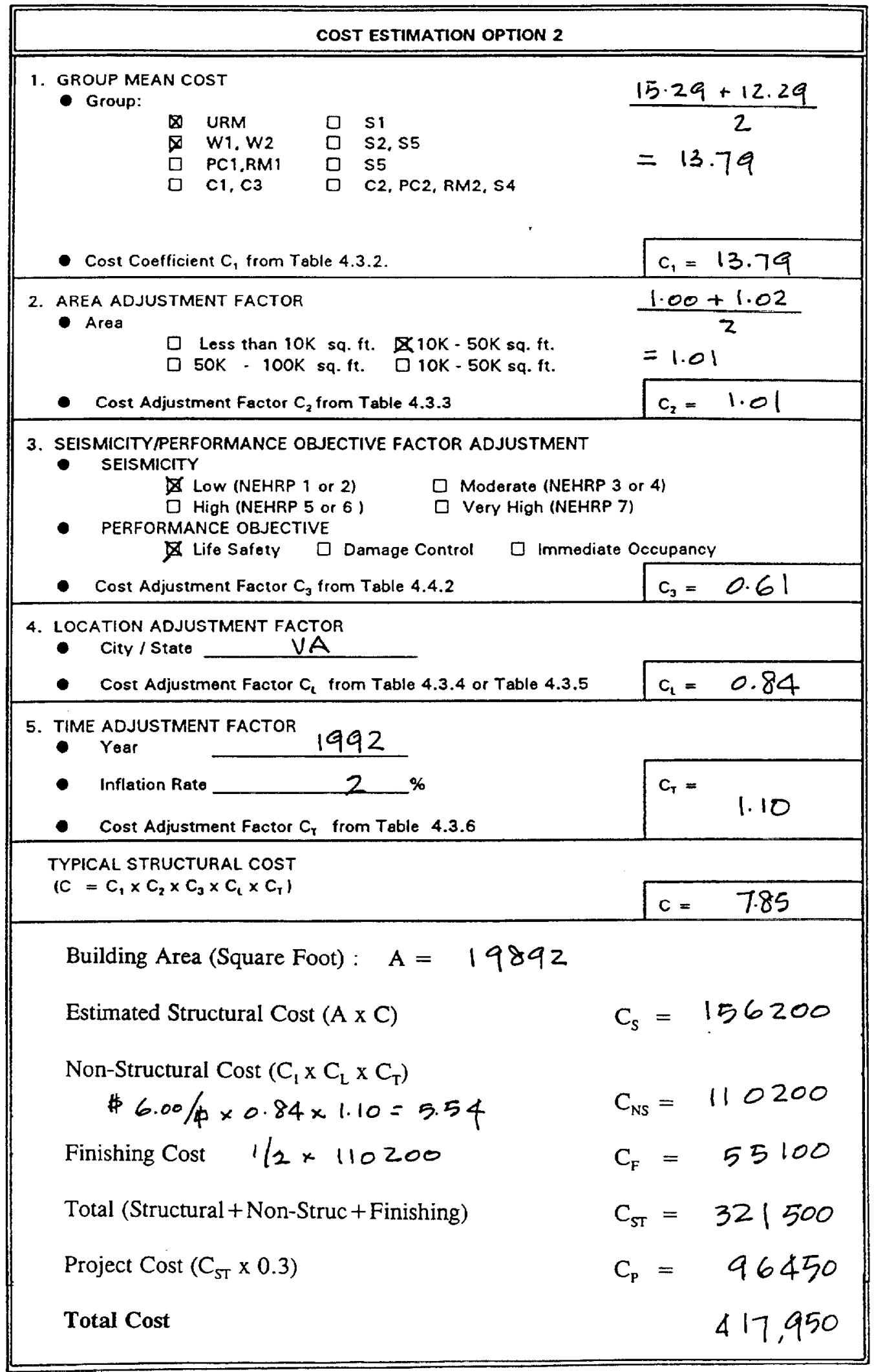


Building Designation :

Bethel VSAB

Location:

Bethel, WA

DATA SUMMARY SHEET

BUILDING DATA

Year built: 1985 Years) remodelled:

Date of Evaluation: $8 / 14198$

Area, (sq. ft.) 30000 Length 200 Width 100 Photo Roll No.

CONSTRUCTION DATA

Rooframing: $z$-purloins + metal deck

Intermediatefloorframing: Steel framing t Conc slab

Exterior walls: CMU/metal Openings: Overhead doors

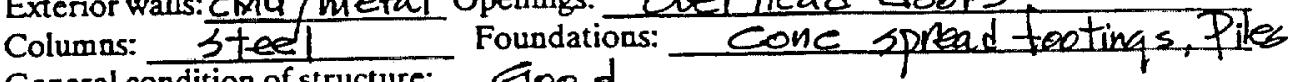

General condition of structure: G700d

Evidence of settling: None

LATERAL FORCE RESISTING SYSTEM

Transverse Longitudinal

Model building type:

Building period, $T$ :

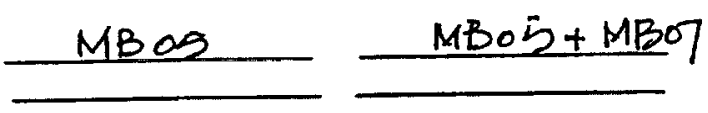

Unreduced base shear,

$$
V=\left[\left(0.80 A_{v} \times S\right) /\left(R \times T^{2 / 3}\right)\right] \times(W) \text { or } V=[2.12 A a / R] \times W
$$

Response Modification Coefficient, $R$ :

5.5

EVALUATION DATA

$$
A_{a}=0.2 \quad A_{v}=0.2
$$

Site soil profile type: $S_{2}$ Site soil coefficient, $S=1 \cdot 2$

REMARKS

seismic design: Zone 3 Ap my manuel TM 5-809-10 (1982) 


\section{EVALUATION STATEMENTS FOR BUILDING TYPE 5: STEEL LIGHT FRAME}

These buildings are pre-engineered and pre-fabricated with transverse rigid frames. The roof and walls consist of light-weight panels. The frames are designed for maximum efficiency, ofien with tapered beam and column sections built up of light plates. The frames are buill in segments and assembled in the field with bolted joints. Lateral loads in the transverse direction are resisted by the rigid frames, with loads distributed to them by shear elements. Loads in the longitudinal direction are resisted entirety by shear elements. The shear elements can be either the roof and wall sheathing panels, an independent system of cension-only rod bracing, or a combination of panels and bracing.

Address the following evaluation statements, marking each either true $(T)$ or false $(F)$. Statements that are found to be true identify issues that are acceptable according to the criteria of this bandbook; statements that are found to be false identify issues that need investigation. For guidance in the investigation, refer to the handbook section indicated in parentheses at the end of the statement.

Be advised that the numerical indices preceded by an asterisk (*) in these statements are based on high seismicity $\left(A_{v}=0.4\right)$. Adjustments are reasonable for lower seismicity. The appropriate adjustment is not necessarily a direct ratio of seismicity.

\section{BUILDING SYSTEMS}

T LOAD PATH: The structure contains a complete load path for seismic force effects from any horizontal direction that serves to transfer the inertial forces from the mass to the foundation (NOTE: Write a brief description of this linkage for each principal direction.) (Sec. 3.1) No lateral load resisting elements in the N-s dir.
at the west end bay

(T) F REDUNDANCY: The structure will remain later ally stable after the failure of any single element. (Sec. 3.2)

(T) F WEAK STORY: Visual observation or a Quick Check indicates that there are no significant strength discontinuities in any of the vertical elements in the lateral-forceresisting system; the story strength at any story is not less than 80 percent of the strength of the story above. (Sec. 3.3.1)

(T) F SOFT STORY: Visual observation or a Quick Check indicates that there are no resisting system; the lateral stiffness of a story is not less than 70 percent of that in the story above or less than 80 percent of the average stiffness of the three stories above. (Sec. 3.3.2)

T F TORSION: The lateral force resisting elements form a well balanced system that is not subject to significant torsion. Significant torsion will be taken as any condition where the distance between the story center of rigidity and the story center of mass is greater than 20 percent of the width of the structure in either major plan dimension. (Sec. 3.3.6) 
(T) F DETERIORATION OF STEEL: There is no significant visible rusting, corrosion, or other deterioration in any of the steel elements in the vertical or lateral-force-resisting systems. (Sec. 3.5.3)

\section{MOMENT FRAMES}

(T) F STRESS CHECK: The building satisfies the Quick Check of the stress in the diagonals. (Sec. 6.1.1)

(T) F BEAM PENETRATIONS: All openings in frame-beam webs bave a depth less that $1 / 4$ of the beam depth and are located in the center half of the beams. (Sec. 4.2.3)

\section{DLAPHRAGMS}

(T) F PLAN IRREGULARITIES: There is significant tensile capacity at re-entrant corners or other locations of plan irregularities. (Sec. 7.1.1)

(T) F REINFORCING AT OPENINGS: There is reinforcing around all diaphragm openings larger than " 50 percent of the building width in either major plan dimension. (Sec. 7.1.3)

\section{CONNECTIONS}

(T) F STEEL COLUMNS: The columns in the lateral-force-resisting system are substantially anchored to the building foundation. (Sec. 8.4.1)

\section{WALL AND ROOF PANELS}

(T) F LIGHT-GAGE METAL, PLASTIC, OR CEMENTITIOUS ROOF PANELS: All lightgage metal, plastic, or cementitious roof panels are properly connected to the roof framing at not more than 12 inches on center. (Sec. 8.6.1)

(T) F WALL PANELS: All wall panels (metal, fiberglass, or cement asbestos) are properly connected to the framing. (Sec. 8.6.2) 
Mars adage Bethel, wa

$1 / 3$

cheER THE WEST END bay of THE VEHCLE barn

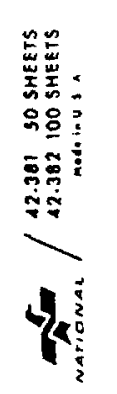

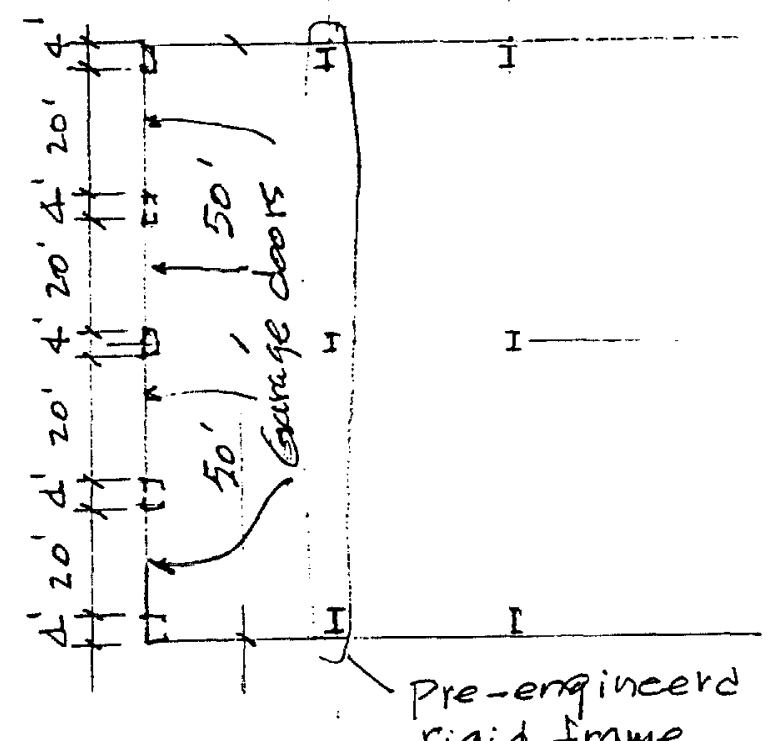
rigid frame,
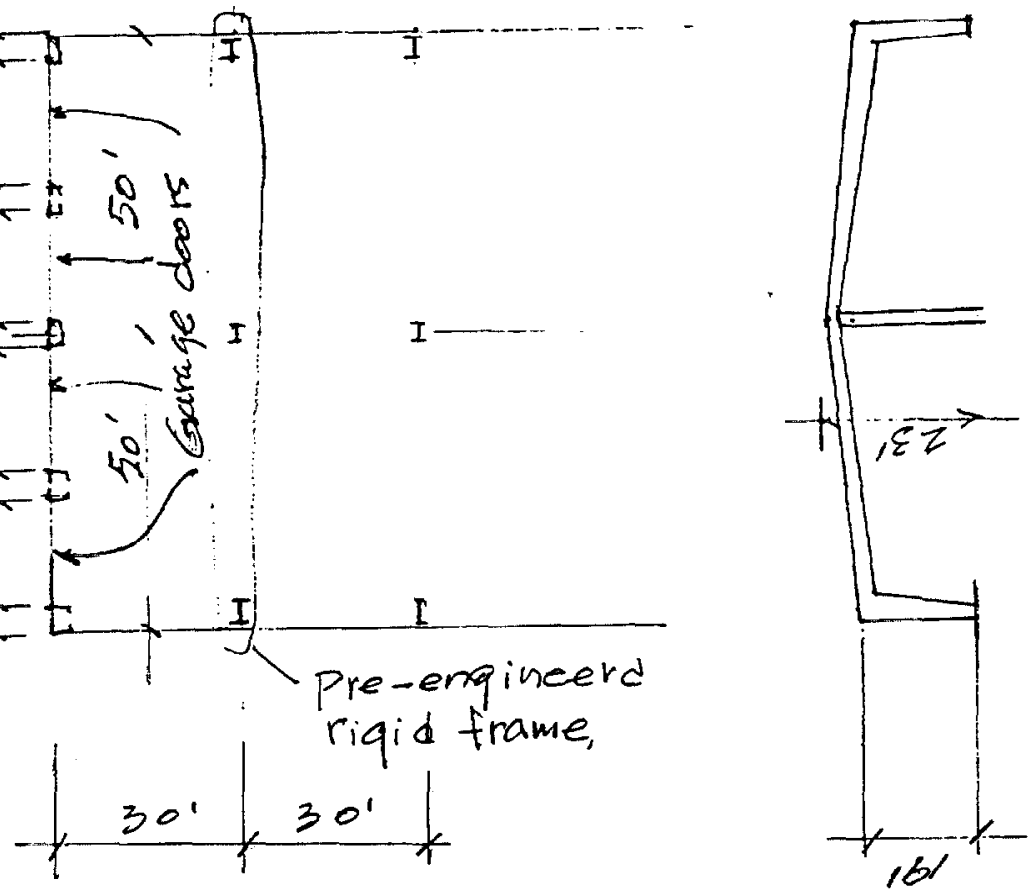

The rigid frame was designed for $z=3$ ULING TM 5-809-10 (1982)

BASE HEAR $V=Z I C K S W$

$$
\begin{aligned}
& Z=0.75 \\
& I=1.5 \\
& K=1.33 \\
& C S=0.14
\end{aligned}
$$

MAsonRy WAs Designed in accordance with TM-5-809-10

The Rigid frames and masonry walls are judged to be deriqued for $U B C$ zone 3

The When end los tl has 4 large garage doors and judged to have inadequate lateral load resisting strength. 
Mors garage | Bethel, wa

$2 / 3$

The end wall is comprised of $108^{\prime \prime} \mathrm{C}$ in the vertical direction. Spaced 4' between two adjacent chancels.

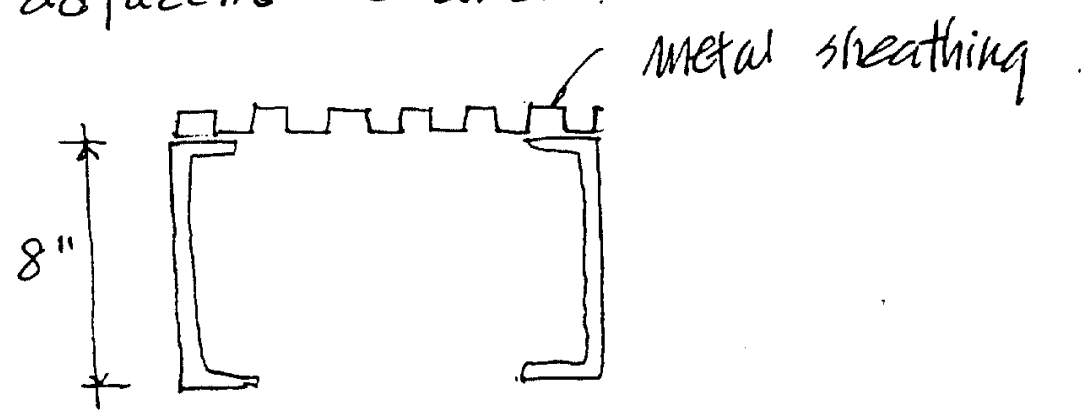

1) Assunive each channel is acting independently.

$$
\begin{aligned}
& \text { e } 8 \times 11.5 \\
& I_{y-y}=1.32^{\text {int }^{4}}
\end{aligned}
$$

Lateral load.

Rot DL: $\quad 4.5$ psf $\times 100^{\prime} \times 15^{1}=6750 \#$

Roof LL: $\quad 25 \times 100 \times 15=37500$

End wall 15 pst $\times 100 \times \frac{19+23}{2}=\frac{31500}{75750}$

$$
\begin{aligned}
V & =\frac{Z I C}{R_{w}} w \\
& =\frac{0.3 \times 1.5(2)}{7} \times 75750=0.128 \times 75750=9739 \# \\
= &
\end{aligned}
$$

Chook simple cantilever beam att.

$$
\Delta=\frac{P l^{3}}{36 I}=\frac{9.7 \times \overline{240} 0^{3}}{3 \times 13.2 \times 29600}=114^{\prime \prime}=0.475 \mathrm{l} \text { ( lifo) }
$$


Mers guragte bothell, wa

36

Buticipation of the reot in seristing the end wall deflection.

8"Z betion@.4'-0"0.c.

$24 z$ purlins.

$$
\begin{aligned}
& I_{y-y}=0.306^{i^{4}} \\
& \sum I_{y-y}=0.306 \times 24=7.344
\end{aligned}
$$

llk" inetal roof panels.

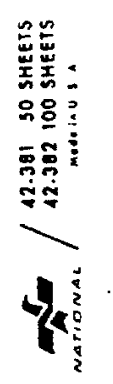

$4 \cdot 4^{k}$

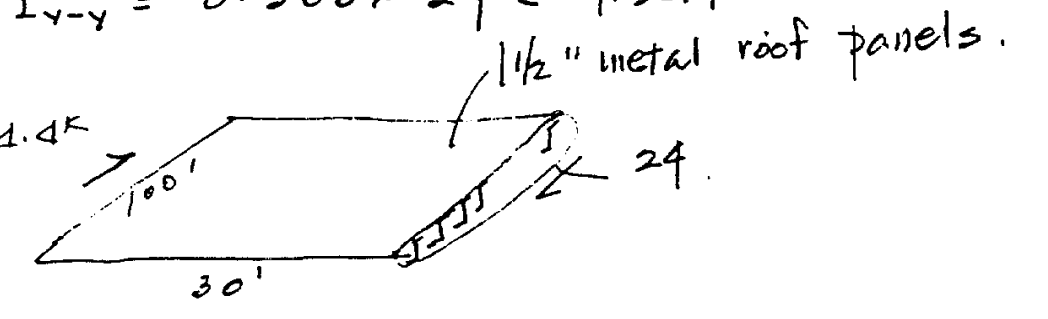

$$
\begin{aligned}
A_{z}= & 0.706 \mathrm{~m}^{2} \\
A d^{2}= & 2\left(0.706 \times \overline{600}^{2}\right)+2\left(0.706 \times \overline{552}^{2}\right)+2\left(0.706 \times \overline{456}^{2}\right) \\
& +2\left(0.706 \times \overline{408}^{2}\right)+2\left(0.706 \times \overline{384}^{2}\right)+2\left(0.706 \times \overline{306}^{2}\right) \\
& +2\left(0.706 \times \overline{288}^{2}\right)+2\left(0.706 \times \overline{240}^{2}\right)+2\left(0.706 \times \overline{192}^{2}\right) \\
& +2\left(0.706 \times \overline{144}^{2}\right)+2\left(0.706 \times \overline{96}^{2}\right)+2\left(0.706 \times \overline{48}^{2}\right) \\
= & 1,355520+430.242+293605 \\
& +235047+208202+159409 \\
& +117117+81331+52052 \\
& +29279+13013+3253
\end{aligned}
$$

$=2978070 \mathrm{~m}^{4}$ Say effective on $30 \%$

$$
\Delta=\frac{P l^{3}}{3 E J}=\frac{4.4 \times\left(12 \times 30^{\circ}\right)^{3}}{3 \times 29600 \times 2978070 \times 0.3}=0.24^{\prime \prime}
$$

very small.

Diaphraqu Shear Transter

$$
\begin{aligned}
V & =1.5 A_{v} C_{p} W_{d} \\
& =1.5 \times 0.2 \times 0.6 \times 44250 \#=7965 \# 0.1 \mathrm{~B} .
\end{aligned}
$$

Table C 6.1 .19

$$
\begin{aligned}
& \text { Table } C 6.11 \mathrm{a} \\
& \text { Cupaity }=1800 \mathrm{fH} / \mathrm{f} \times 100 \mathrm{ft}=180000^{\#}
\end{aligned}
$$


Building Designation :

$D$

Location:

Emmittsburg, MD

\section{DATA SUMMARY SHEET}

\section{BUILDING DATA}

Year built: 1929 Year(s) remodelled:

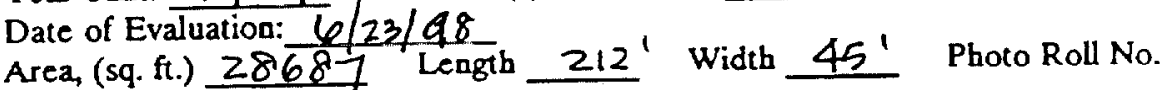

\section{CONSTRUCTION DATA}

Rooframing: Concrete Trusses

Intermediatefloorframing: Wood beams

Ground floor: 50 ovete Basement: Coperete

Exterior walls brick Masomry Openings: Windows

Column: Done Foundations: stone+Brick masoury

General condition of structure:

Evidence of settling: None

\section{LATERAL FORCE RESISTING SYSTEM}

Transverse Longitudinal

Model building type:

Building period, $T$ :

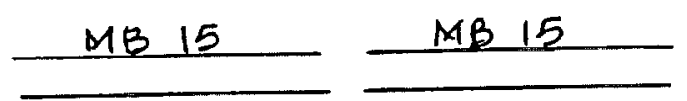

Unreduced base shear, $V=\left[\left(0.80 A_{v} \times S\right) /\left(R \times T^{2 / 3}\right)\right] \times(W)$ or $V=[2.12 \mathrm{Aa} / R] \times W$

Response Modification Coefficient, $R$ :

1.25

\section{EVALUATION DATA}

$A_{a}=0.05 \quad A_{v}=0.05$

Site soil profile type: $S_{2}$ Site soil coefficient, $S=1.2$

REMARKS

Being used as dormitory 


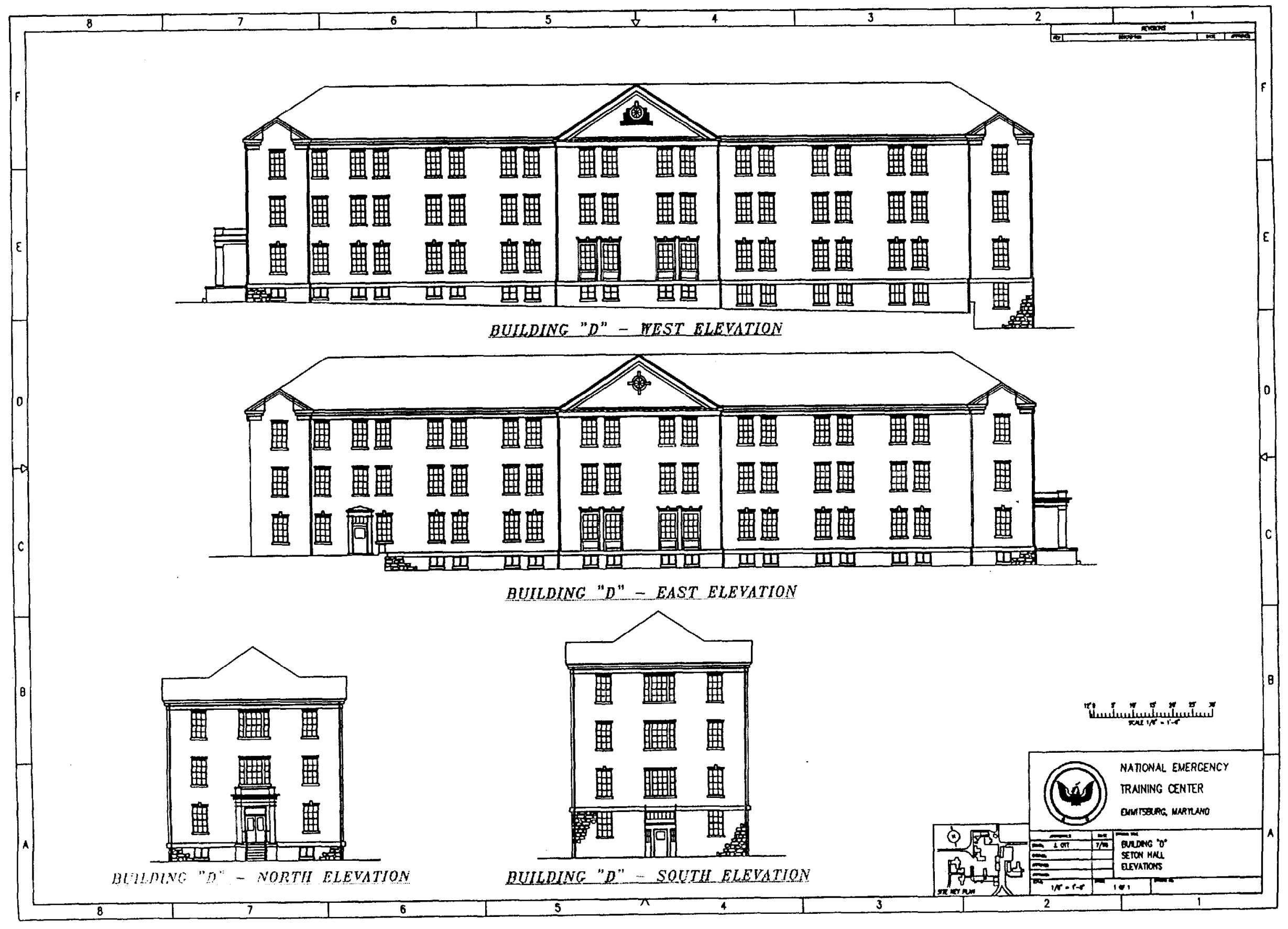




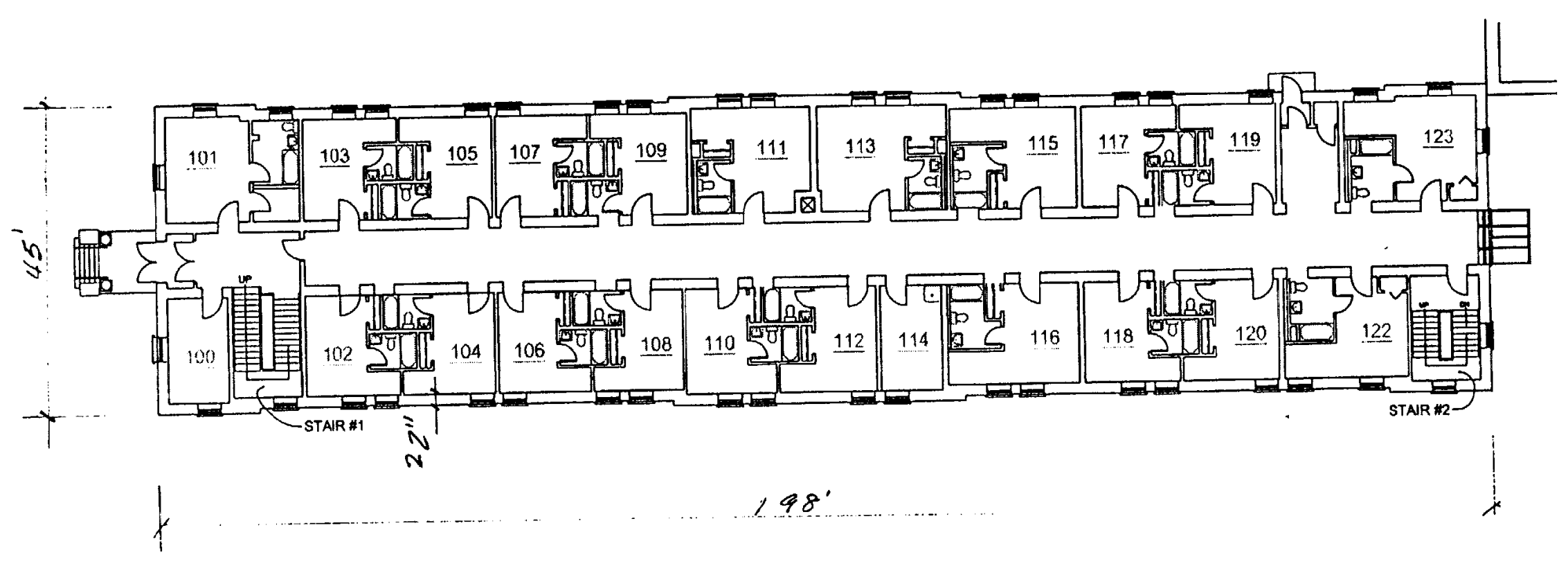




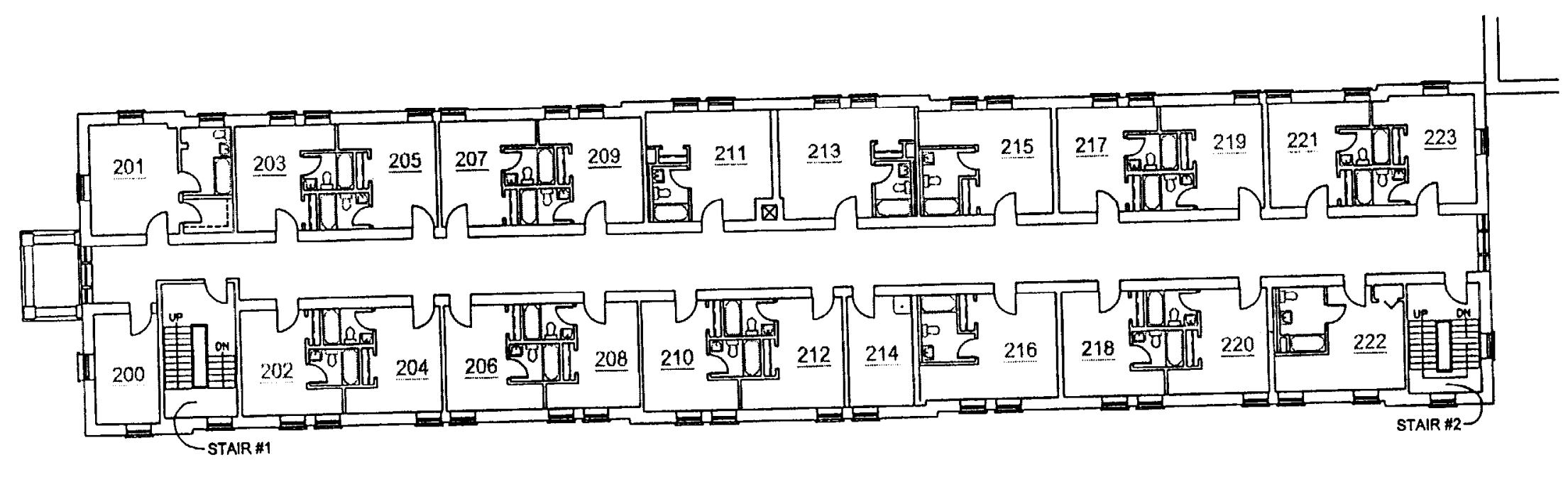




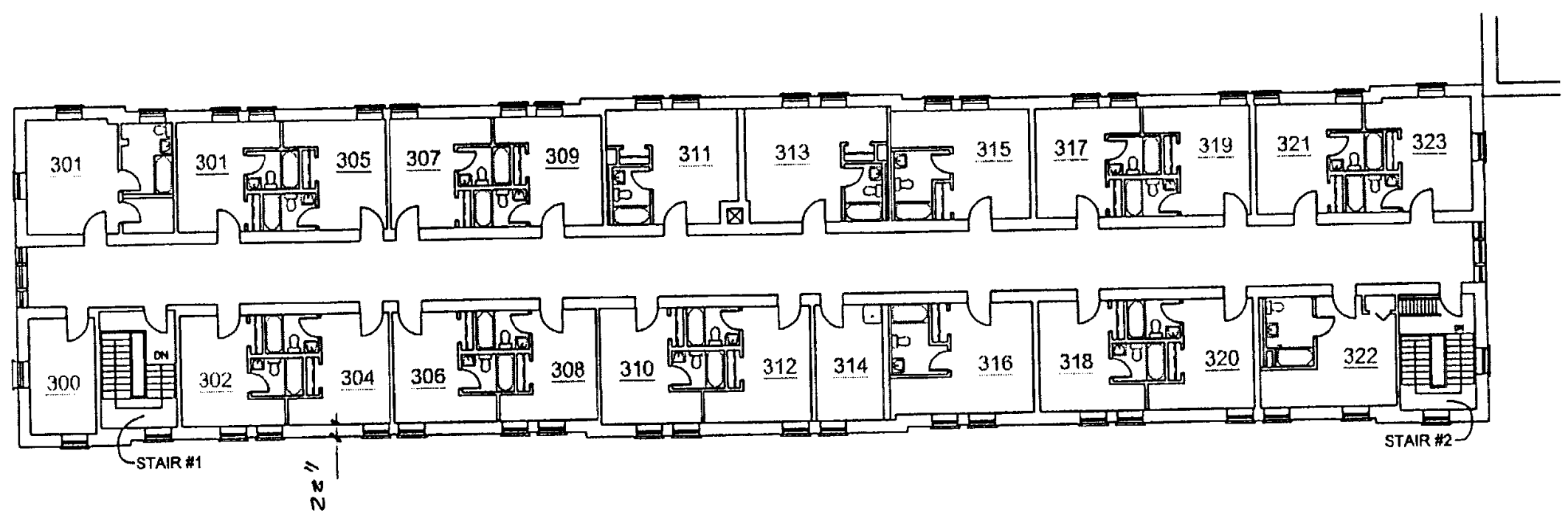




\section{EVALUATION STATEMENTS FOR BUILDING TYPE 15: UNREINFORCED MASONRY BEARING WALL BUILDINGS}

These buildings include structural elements that vary depending on the age of the building and, 10 a lesser ertent, the geographic location of the structure. In buildings built before 1900, the majority of floor and roof construction consists of wood sheathing supported by wood subframing. In large multistory buildings, the floors are cast-in-place concrete supponed by the unreinforced masony walls and/or steel or concrete interior framing. In buildings built after 1950, unreinforced masonry buildings with wood floors usually have plywood rather than board sheathing. More recently, in regions of lower seismicity, these buildings can include floor and roof framing that consists of metal deck and concrete fill supported by steel framing elements. The perimeter walls, and possibly some interior walls, are unreinforced masonn. The walls may or may not be anchored to the diaphragms. Ties between the walls and diaphragms are more common for the bearing walls than for walls that are paralle! to the floor framing. Roof ties usually are less common and more erratically spaced than those at the floor levels. Interior pantitions that interconnect the floors and roof can have the effect of reducing diaphragm displacements.

Address the following evaluation statements, marking each either true (T) or false (F). Statements that are found to be true identify issues that are acceptable according to the criteria of this handbook; statements that are found to be false identify issues that need investigation. For guidance in the investigation, refer to the handbook section indicated in parentheses at the end of the statement.

Be advised that the numerical indices preceded by an asterisk (") in these statements are based on high seismicity $\left(A_{v}=0.4\right)$. Adjustments are reasonable for lower seismicity. The appropriate adjustment is not necessarily a direct ratio of seismicity.

\section{BUILDING SYSTEMS}

(T) F LOAD PATH: The structure contains a complete load path for seismic force effects from any horizontal direction that serves to transfer the inertial forces from the mass to the foundation (NOTE: Write a brief description of this linkage for each principal direction.) (Sec. 3.1)

(T) F REDUNDANCY: The structure will remain laterally stable after the failure of any single element. (Sec. 3.2)

(T) F WEAK STORY: Visual observation or a Quick Check indicates that there are no significant strength discontinuities in any of the vertical elements in the lateral-forceresisting system; the story strength at any story is not less than 80 percent of the strength of the story above. (Sec. 3.3.1)

SOFT STORY: Visual observation or a Quick Check indicates that there are no significant stiffaess discontinuities in any of the vertical elements in the lateral-forceresisting system; the lateral stiffness of a story is not less than 70 percent of that in the story above or less than 80 percent of the average stiffness of the three stories above. (Sec. 3.3.2) 
(T) F GEOMETRY: There are no significant geometrical irregularities; there are no setbacks (i.e., no changes in horizontal dimension of the lateral-force-resisting system of more than 30 percent in a story relative to the adjacent stories). (Sec. 3.3.3)

T (F) MASS: There are no significant mass irregularities; there is no change of effective mass of more than 50 percent from one story to the next, excluding light roofs. (Sec. 3.3.4)

(T) F VERTICAL DISCONTINUITIES: All shear walls are continuous to the foundation. (Sec. 3.3.5)

T F TORSION: The lateral force resisting elements form a well balanced system that is not subject to significant torsion. Significant torsion will be taken as any condition where the distance between the story center of rigidity and the story center of mass is greater than 20 percent of the width of the structure in either major plan dimension. (Sec. 3.3.6)

(T) F ADJACENT BUILDINGS: There is no immediately adjacent structure that is less than half as tall or has floors/levels that do not match those of the building being evaluated. A neighboring structure is considered to be "immediately adjacent" if it is within 2 inches times the number of stories away from the building being evaluated. (Sec. 3.4)

(T) F MASONRY UNTTS: There is no visible deterioration of large areas of masonry units. (Sec. 3.5.10)

(T) F MASONRY JOINTS: The mortar cannot be easily scraped away from the joints by hand with a metal tool, and there are no significant areas of eroded mortar. (Sec. 3.5.9)

For buildings with wood diaphragms and unreinforced masonry bearing and enclosure walls at the perimeter, complete the evaluation using the procedure given in Appendix C. For other buildings, continue with the following evaluation statements.

\section{MASONRY WALLS}

(T) F SHEARING STRESS CHECK: The building satisfies the Quick Check of the shearing stress in the unreinforced masonry shear walls. (Sec. 5.4.1)

(T) F PROPORTIONS: In areas of high seismicity $\left(A_{v}\right.$ greater than or equal to 0.2$)$, the heightthickness "ratio of the unreinforced masonry wall panels is as follows: (Sec. 5.5.1; also see Appendix C)

- One-story building:

- Multistory building:

Top story:

Other stories:

$$
\begin{aligned}
h_{W \sigma} / t & <14 \\
h_{\omega \sigma} / t & <9 \\
h_{\omega N} / t & <20
\end{aligned}
$$

(T) F MASONRY LAY-UP: Filled collar joints of multiwythe masonry walls have negligible voids. (Sec. 5.4.2) 


\section{DIAPHRAGMS}

(T) F PLAN IRREGULARITIES: There is significant tensile capacity at re-entrant corners or other locations of plan irregularities. (Sec. 7.1.1)

(T) F REINFORCING AT OPENINGS: There is reinforcing around all diaphragm openings larger than " 50 percent of the building width in either major plan dimension. (Sec. 7.1.3)

(T) F SPAN/DEPTH RATIO: If the span/depth ratios of wood diaphragms are greater than 3 to 1 , there are nonstructural walls connected to all diaphragm levels at less than 40 -foot spacing. (Sec. 7.2.4)

(T) F SHEATHING: None of the diaphragms consist of straight sheathing or have span/depth ratios greater than 2 to 1 . (Sec. 7.2 .1 )

\section{CONNECTIONS}

(T) F MASONRY WALL ANCHORS: Wall anchorage connections are steel anchors or straps that are developed into the diaphragm. (Sec. 8.2.3)

(T) F ANCHOR SPACING: The anchors from the floor and roof systems into exterior masonry walls are spaced at 4 feet or less. (Sec. 8.2.4) 


$\mid \begin{aligned} & \text { Bide D } D \\ & \text { CHeck hit ratio. } \\ & \text { top story }=\frac{144}{22}=6.54<9 \quad 0 . k \\ & 14 \text { story }=6.54<20 \text { oik }\end{aligned}$

W qt of Bldg

Longitudinal Wall: $198 \times 36=7128$

$$
\text { Windows: }(19 \text { windows } \times 28) \times 3=\frac{1596}{5532^{\text {中 }}}
$$

Transverse (end) $45 \times 36=1620$

$$
\begin{aligned}
(12 \times 28) \times 3 & =\frac{1008}{612^{4}} \\
\text { Net SRSA } & =1620
\end{aligned}
$$

Wall surface area:

$$
(5532+612) \times 2=12288 \text { 中. }
$$

$\Sigma$ Weight $12288 \times 243 \%$ \% $=2,985,984$

Partition (121/2" Cone Block).

$$
194^{\prime} \times 10^{\circ}=1940^{\prime}
$$

Doors $17 \times 3.5^{1} \times 8^{\prime}=\frac{476}{1464 \text {. }}$ Story $\times 80^{7 / \phi} \times 2=233,600^{*}$

INTERTOR Part. $\left(8^{\mathrm{N}}\right)$

$$
18^{\prime} \times 10^{1} \times 17 \times 55 \%=168300 \# / \text { story }
$$

3 storied $\times(233600+168,300)=1,205,700$. 
Bldg D.

$8-22-98$

$2 / 3$

Roof : Cone.

CEILING

$$
110^{\prime} / f^{3} \times 45^{1} \times 198^{1} \times 0.83^{1}=813,483^{\#}
$$

Roof

$110 \times 50^{1} \times 198 \times 0.67=694,465$

Truss $694465 \times 0.2=\frac{139293}{1,647,241}$

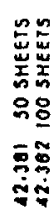

$2^{\text {nd }} \leqslant 3^{\text {rd }} \mathrm{fl}$

$$
43^{1} \times 196^{1} \times 8^{* 10}=\frac{67424^{*}}{\frac{67424}{134848}}
$$

Total DEAD Load at lIst Fl Level

$$
\begin{aligned}
& 2985984 \\
& 1205700 \\
& 1647241 \\
& 134848 \\
& 5,973800
\end{aligned}
$$

$$
\begin{aligned}
& V=C_{s} W=0.17 \times 5973800 \cong 1,015,500 \# \\
& C_{s}=\frac{2.12 A_{a}}{R}=\frac{2.12 \times 0.1}{1.25}=0.17 \quad \text { (short period bide) } \\
& \text { Net } A=\left[(1981-19 \times 4) \times \frac{22}{12}\right] 2=4474 \\
& r=\frac{1015500}{447 \times 12 \times 12}=15.8 p 4 i \times 1.25=19.75 \mathrm{psi} \\
& V_{m}=0.56 V_{w}+\frac{0.75 P_{D}}{\Delta}=0.56 \times 60+\frac{0.75(5973800)}{447 \times 144} \\
& =33.6+69.6=103 \text { psi 0. }
\end{aligned}
$$




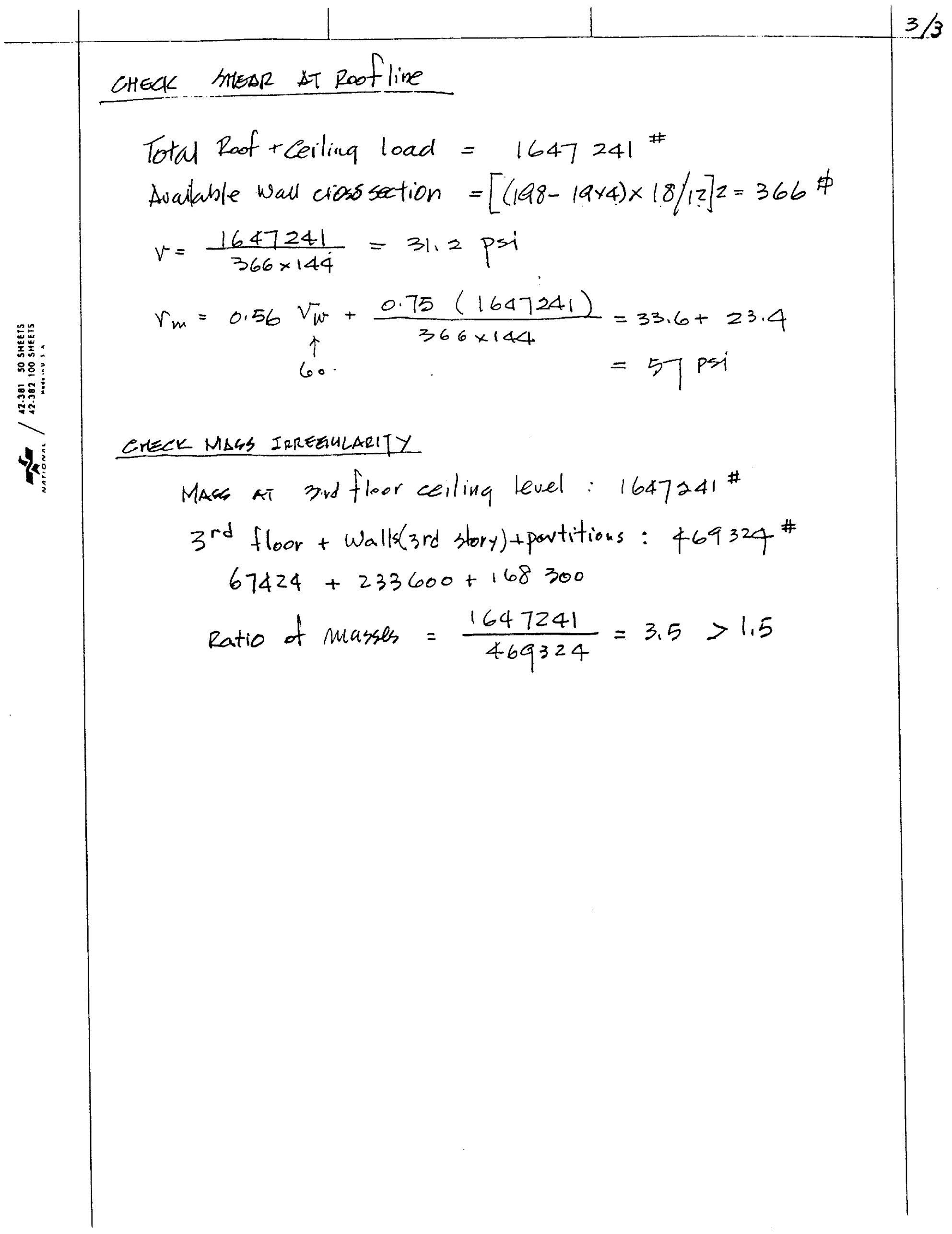


Building Designation :

J

Location: Emmittsburg, MD

\section{DATA SUMMARY SHEET}

\section{BUILDING DATA}

Year built: 1965 Year(s) remodelled: 1992 (non-structaval)

Date of Evaluation: 6/23/98

Area, (sq. ft.) $\$ 5673$ Length H/A Width elA Photo Roll No.

\section{CONSTRUCTION DATA}

Rooframing: Concrete joists

Intermediatefloorframing: Conevete joists

Ground floor: Conc. Joists Basement: Concrete

Exterior walls: Nobon ty intill Openings:

Columns: Concrete

Foundations:

General condition of structure:

Evidence of settling: Hone

\section{LATERAL FORCE RESISTING SYSTEM}

\section{Transverse \\ Longitudinal}

Model building type:

Building period, $T$ :

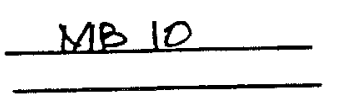

$M B 10$

Unreduced base shear,

$V=\left[\left(0.80 A_{v} \times S\right) /\left(R \times T^{2 / 3}\right)\right] \times(W)$ or $V=[2.12 \mathrm{~A} a / R] \times W$

Response Modification Coefficient, $R$ :

5

\section{EVALUATION DATA}

$A_{a}=\underline{0.05} \quad A_{v}=\underline{0.05}$

Site soil profile type: $S_{2}$ Site soil coefficient, $S=1.2$

REMARKS 


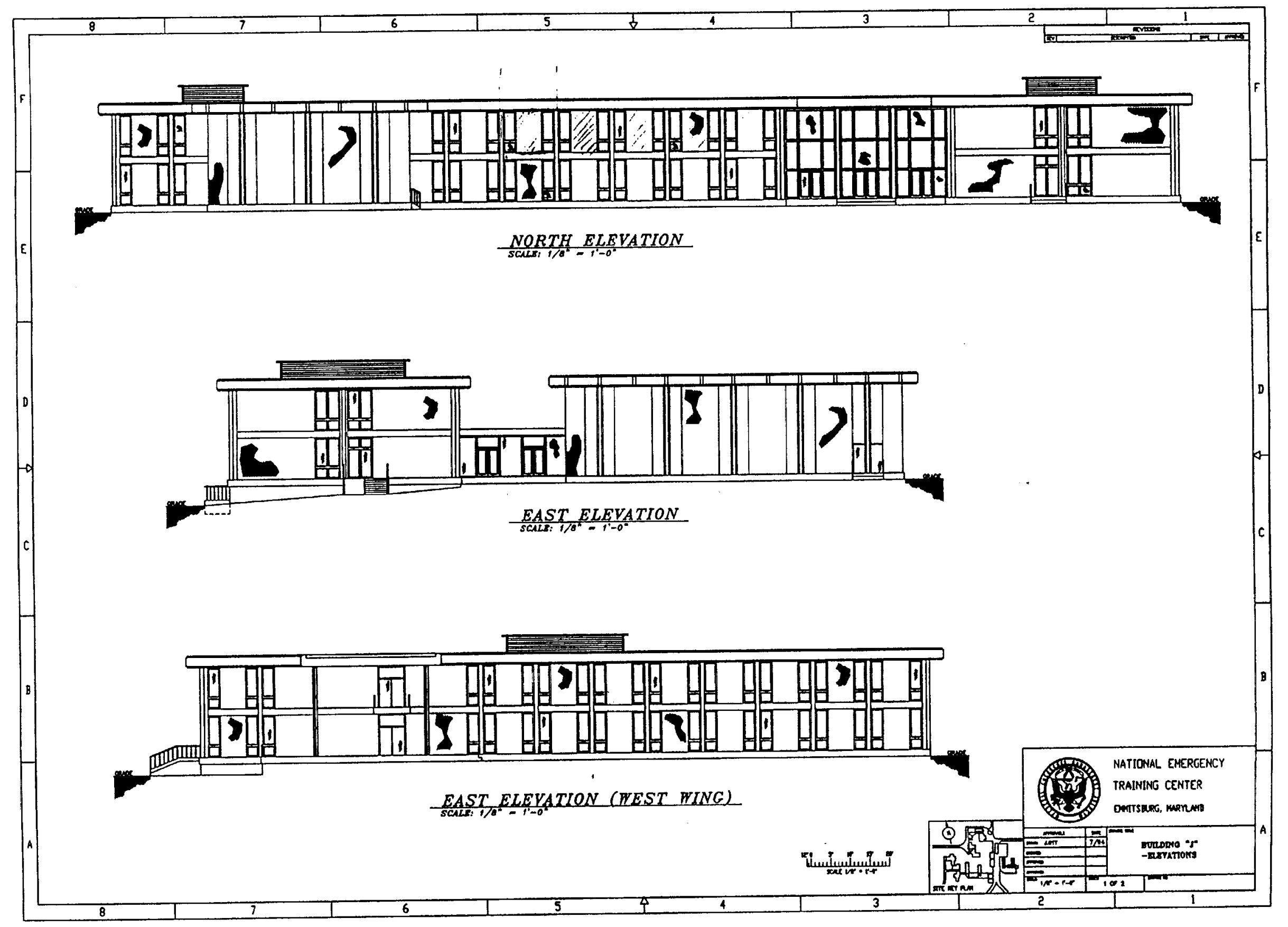




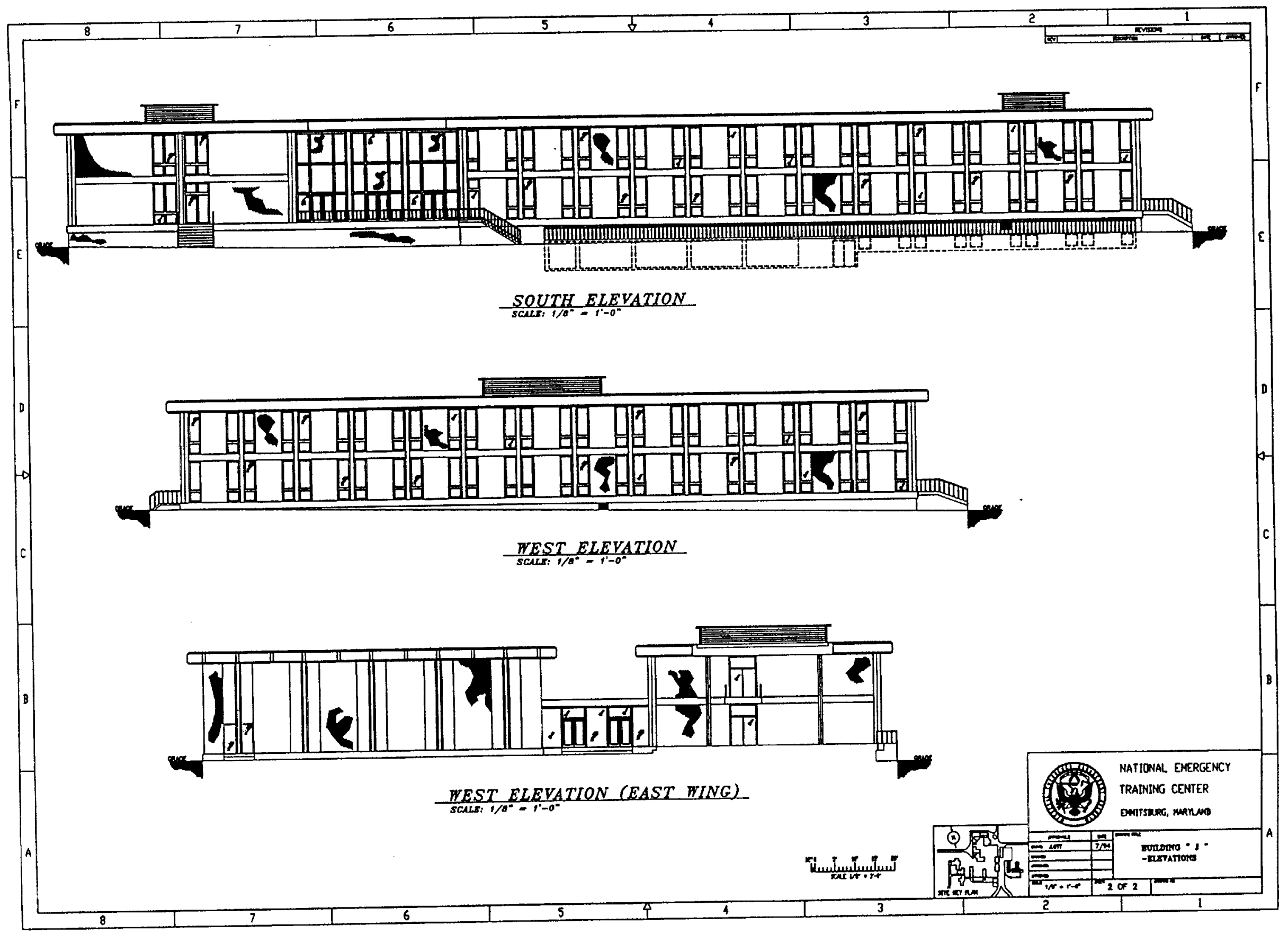




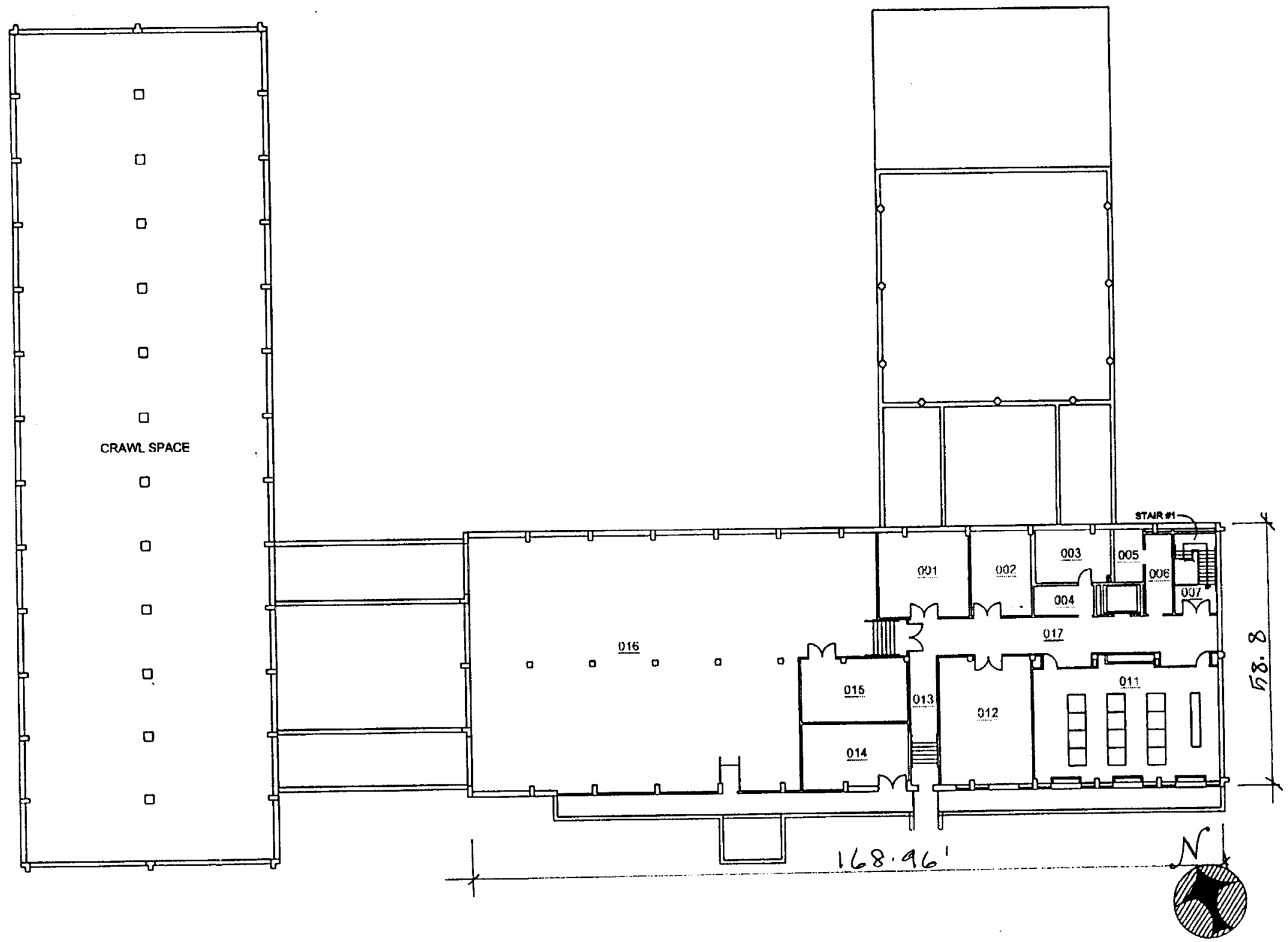

NATIONAL EMERGENCY TRAINING CENTER
BUILDING J BASEMENT FLOORPLAN

01/20198

N.T.S. 

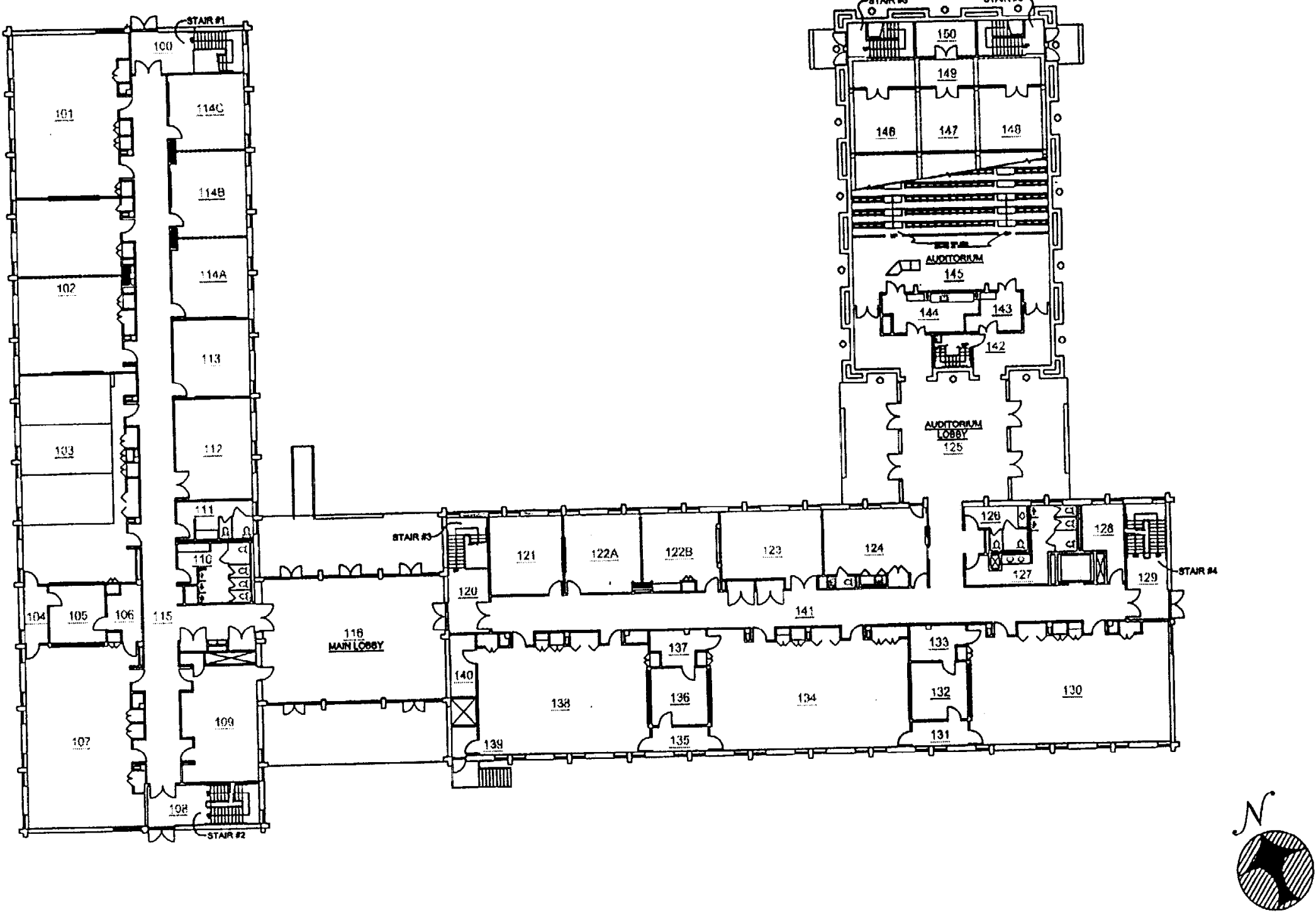

NATIONAL EMERGENCY TRAINING CENTER 

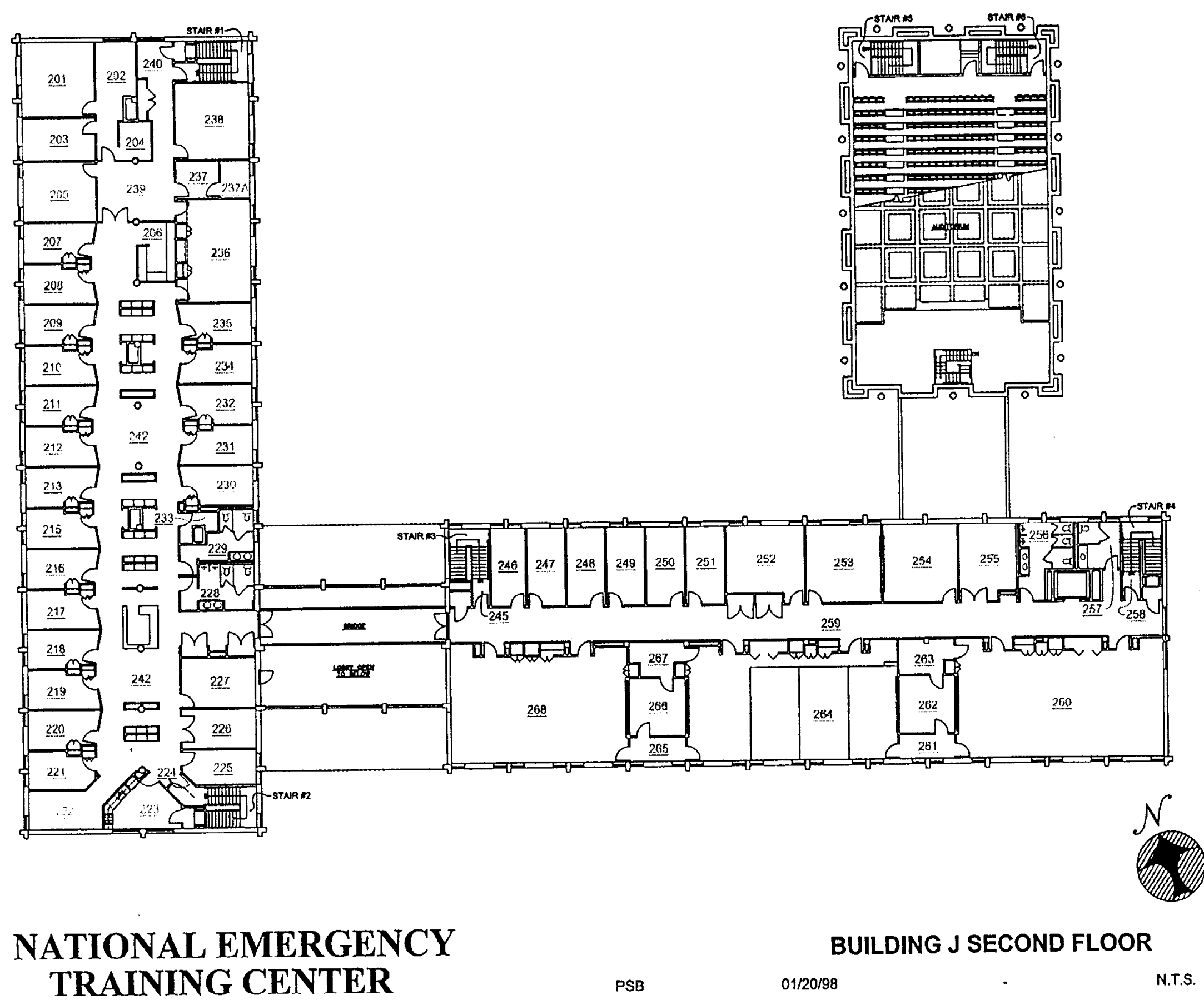
TRAINING CENTER 


Bidq. $J$, Emmittsburq, MD

\section{EVALUATION STATEMENTS FOR BUILDING TYPE 10: CONCRETE FRAME WTTH INFILL SHEAR WALLS}

These buildings are similar to Type 7 except that the frame is of reinforced concrete. The analysis of this building is similar to that recommended for Type 7 except that the shear strength of the concrete columns, after cracking of the infill, may limit the semiductile behavior of the system. Research that is specific to confinement of the infill by reinforced concrete frames should be used for the analysis.

Address the following evaluation statements, marking each either true (T) or false (F). Statements that are found to be true identify issues that are acceptable according to the criteria of this handbook; statements that are found to be false identify issues that need investigation. For guidance in the investigation, refer to the handbook section indicated in parentheses at the end of the statement.

Be advised that the numerical indices preceded by an asterisk $\left(^{*}\right)$ in these statements are based on high seismicity $\left(A_{v}=0.4\right)$. Adjustments are reasonable for lower seismicity. The appropriate adjustment is not necessarily a direct ratio of seismicity.

\section{BUILDING SYSTEMS}

(T) LOAD PATH: The structure contains a complete load path for seismic force effects from any horizontal direction that serves to transfer the inertial forces from the mass to the foundation (NOTE: Write a brief description of this linkage for each principal direction.) (Sec. 3.1)

(T) F REDUNDANCY: The structure will remain laterally stable after the failure of any single element. (Sec. 3.2)

(T) F WEAK STORY: Visual observation or a Quick Check indicates that there are no significant strength discontinuities in any of the vertical elements in the lateral-forceresisting system; the story strength at any story is not less than 80 percent of the strength of the story above. (Sec. 3.3.1)

F SOFT STORY: Visual observation or a Quick Check indicates that there are no significant stiffness discontinuities in any of the vertical elemeats in the lateral-forceresisting system; the lateral stiffness of a story is not less than 70 percent of that in the story above or less than 80 percent of the average stiffness of the three stories above. (Sec. 3.3.2)

(T) F MASS: There are no significant mass irregularities; there is no change of effective mass of more than 50 percent from one story to the next, excluding light roofs. (Sec. 3.3.4)

(T) F VERTICAL DISCONTINUITIES: All infill walls are continuous to the foundation. (Sec. 3.3.5)

(T) F TORSION: The lateral force resisting elements form a well balanced system that is not subject to significant torsion. Significant torsion will be taken as any condition where the distance between the story center of rigidity and the story center of mass is greater than 20 percent of the width of the structure in either major plan dimension. (Sec. 3.3.6) 
(T) F MASONRY JOINTS: The mortar cannot be easily scraped away from the joints by hand with a metal tool, and there are no significant areas of eroded mortar. (Scc. 3.5.9)

(T) F CRACKS IN INFILL WALLS: There are no diagonal cracks in the infilled walls that extend throughout a panel or are greater than $1.0 \mathrm{~mm}$ wide. (Sec. 3.5.11)

(T) F CRACKS IN BOUNDARY COLUMNS: There are no diagonal cracks wider than 1.0 $\mathrm{mm}$ in concrete columus that encase the masonry infulls. (Sec. 3.5.7)

\section{SHEAR WALLS}

(T) F SHEARING STRESS CHECK: The building satisfies the Quick Check of the shearing stress in the masonry infill walls. (Sec. 5.3.1 for reinforced masonry; Sec. 5.4.1 for uareinforced masonry)

(T) F PROPORTIONS: In areas of high seismicity ( $A_{v}$ greater than or equal to 0.2 ), the heightthickness "ratio of the unreinforced masonry wall panels is as follows: (Sec. 5.5.1; also see Appendix C)

- One-story building:

- Multistory building: Top story: Other stories:

$$
\begin{aligned}
& h_{w} / t<14 \quad \frac{12 \times 12}{12}=12<14 \\
& h_{k} / t<9 \\
& h_{k} / t<20
\end{aligned}
$$

(T) F SOLID WALLS: The infilled walls are not of cavity construction. (Sec. 5.5.2)

(T) F CAVTTY WALLS: The infill walls are continuous to the soffits of the frame beams. (Sec. 5.5.3)

T F WALl CONNECTIONS: All infill panels are constructed to encompass the frames around their entire perimeter. (Sec. 5.5.4)

(T) F REINFORCING: In areas of high seismicity ( $A_{v}$ greater than or equal to 0.2$)$, the total vertical and horizontal reinforcing steel in reinforced masonry walls is greater than 0.002 times the gross area of the wall with a minimum of 0.0007 in either of the two directions; the spacing of reinforcing steel is less than 48 inches; and all vertical bars extend to the top of walls. (Sec. 5.3.2) $\mathrm{N} / \mathrm{A}$

\section{MOMENT FRAMES}

(T) F COMPLETE FRAMES: The concrete frames form a complete vertical load carrying system. (Sec. 4.5.1)

\section{DLAPHRAGMS}

(T) F PLAN IRREGULARITIES: There is significant tensile capacity at re-entrant corners or other locations of plan irregularities. (Sec. 7.1.1) N/A

(T) F REINFORC̣ING AT OPENINGS: There is reinforcing around all diaphragm openings larger than 50 percent of the building width in either major plan dimension. (Sec. 7.1.3) $N / A$ 

(T) F SPAN/DEPTH RATIO: If the span/depth ratios of wood diaphragms are greater than
3 to 1 , there are nonstructural walls connected to all diaphragm levels at less than 40 foot spacing. (Sec. 7.2.4)

\section{CONNECTIONS}

$\mathbf{T}$

F WALL ANCHORAGE: The exterior concrete or masonry walls are anchored to each of the diaphragm levels for out-of-plane loads. (Sec. 8.2.2)

$$
\text { Not known }
$$




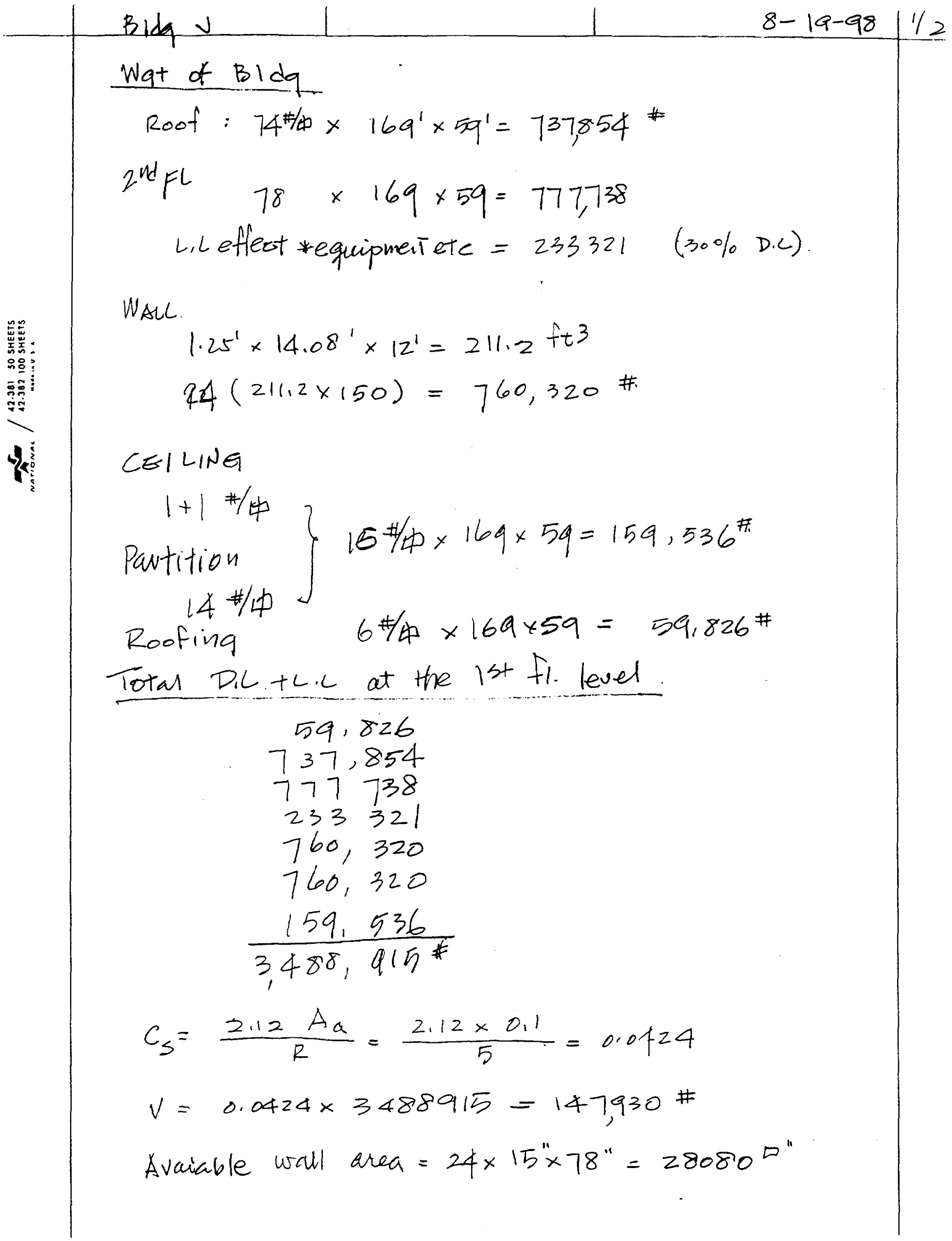




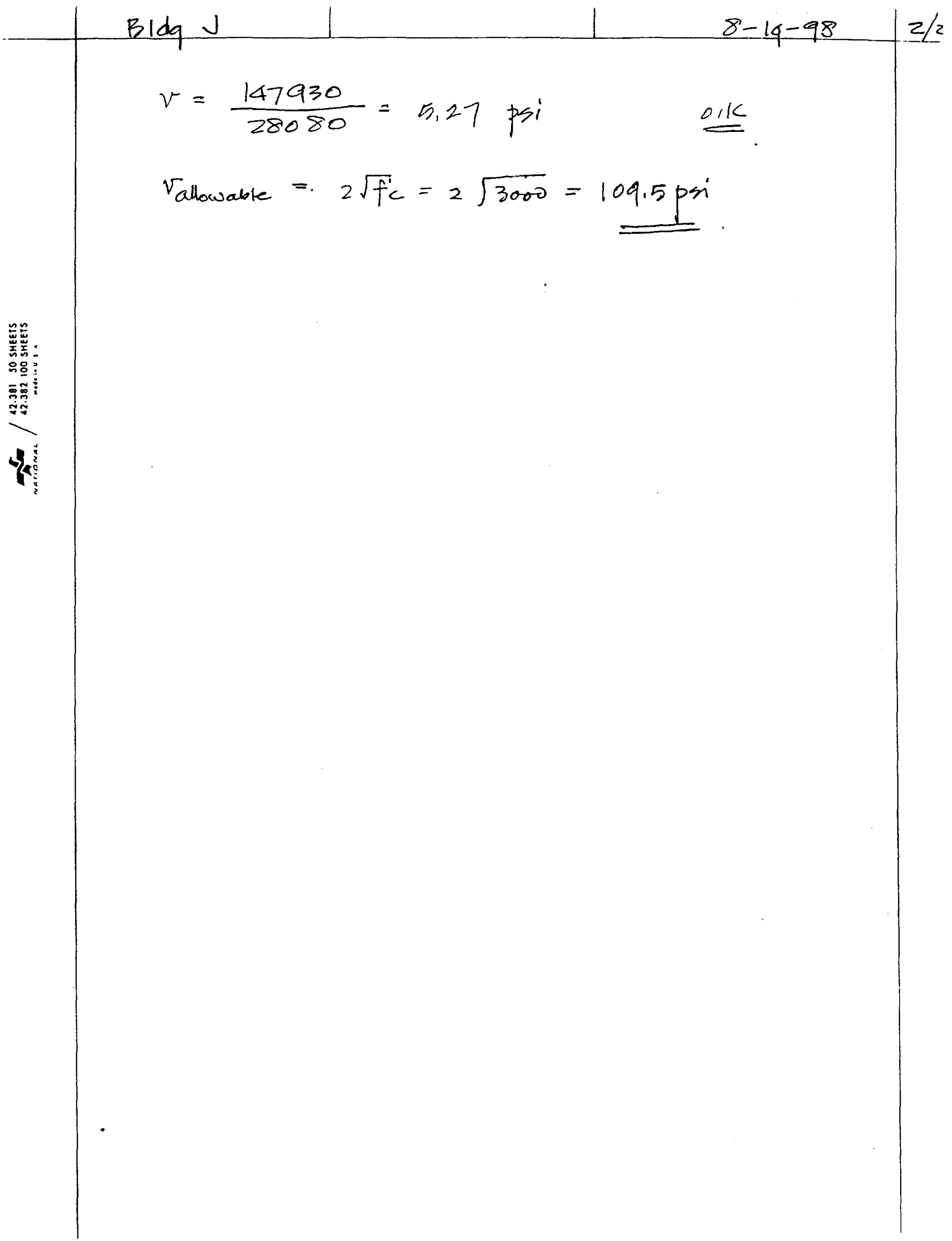




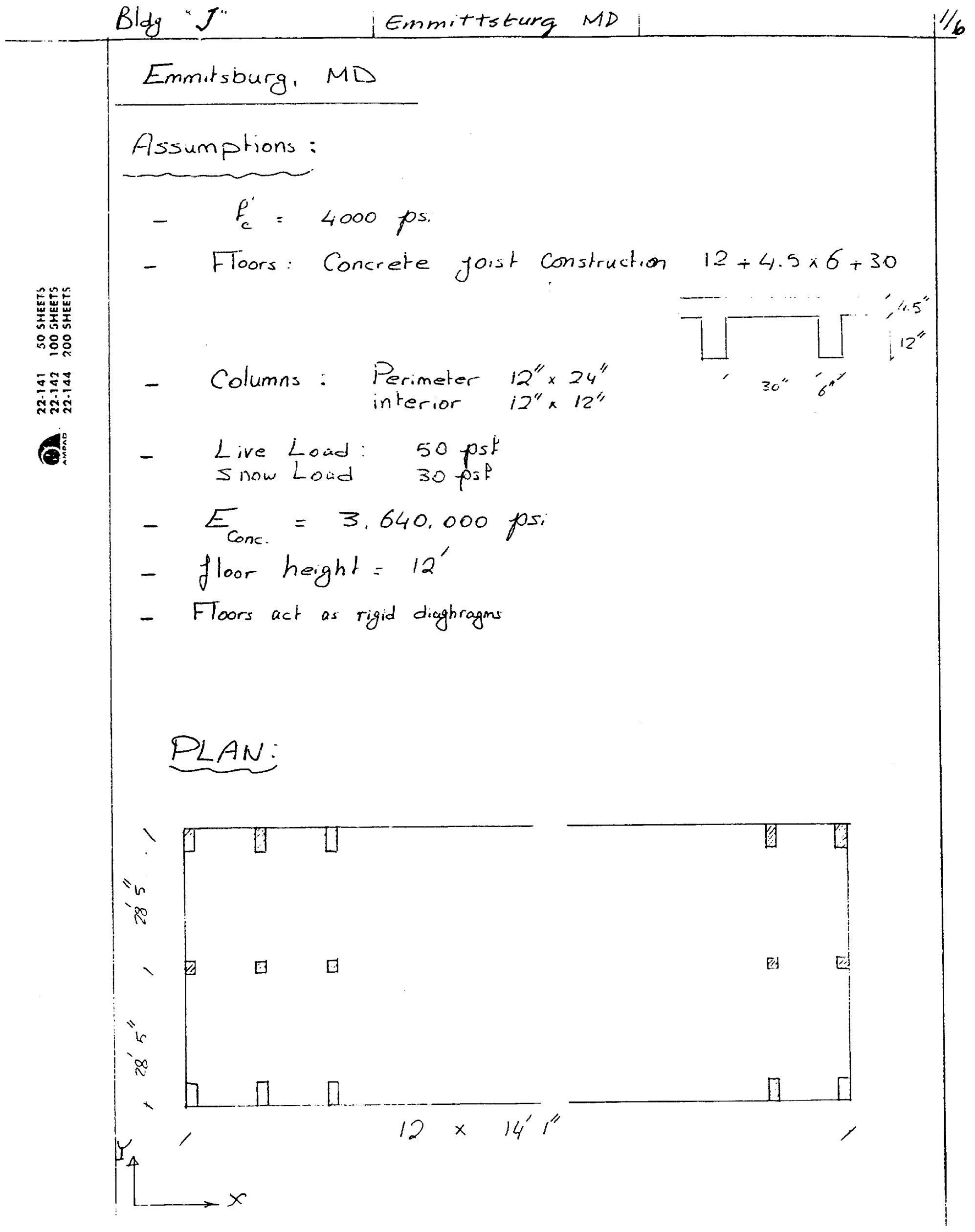




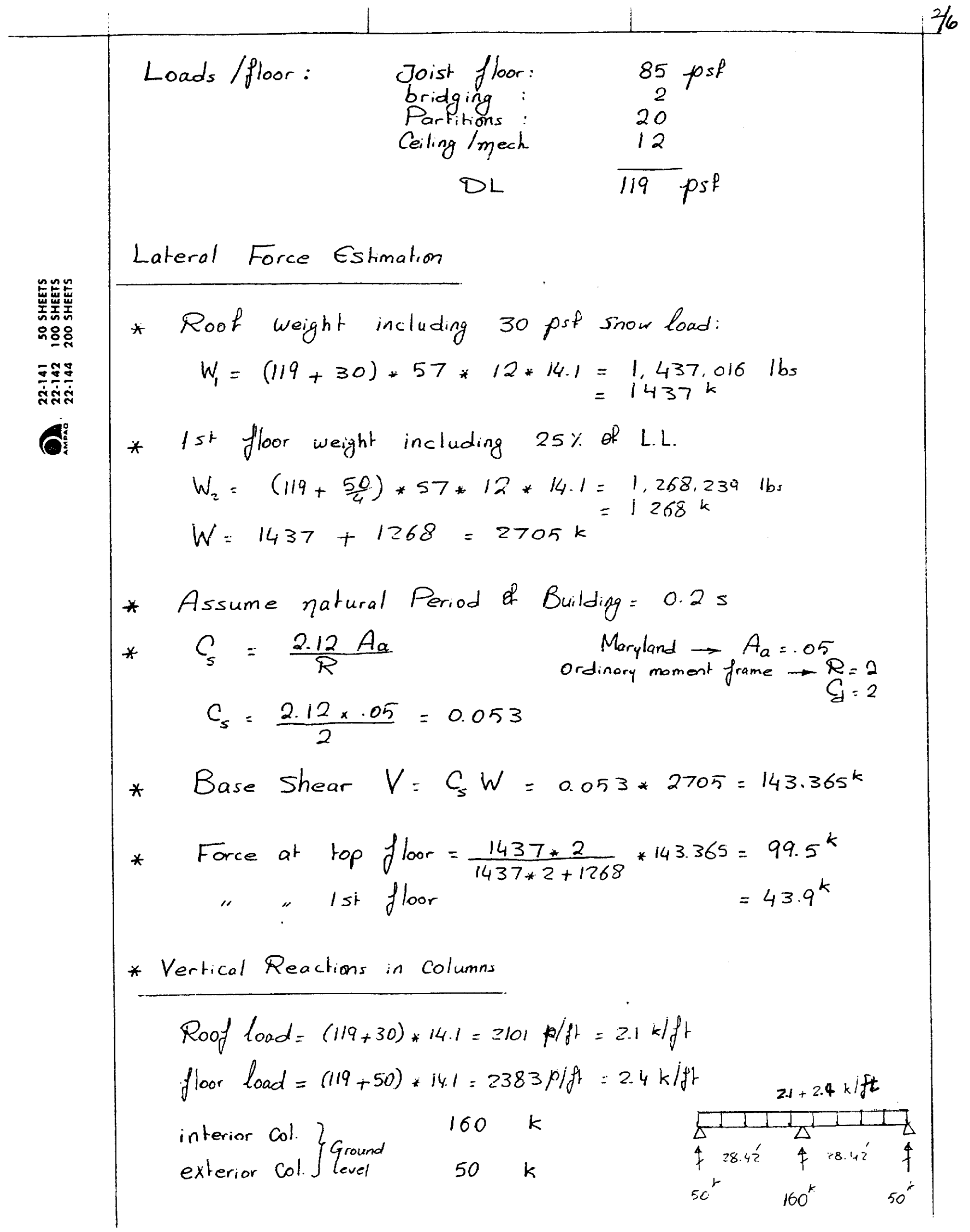




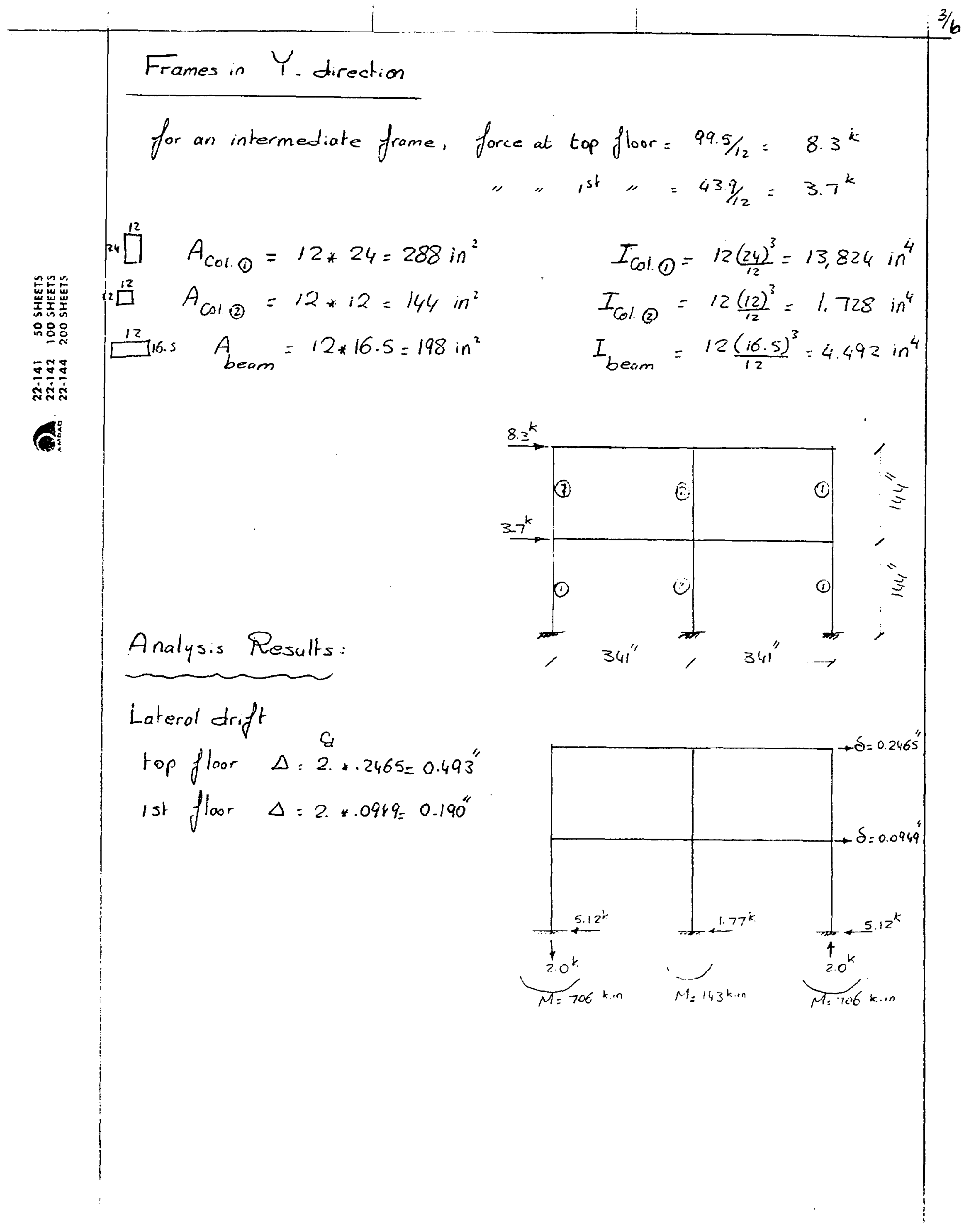




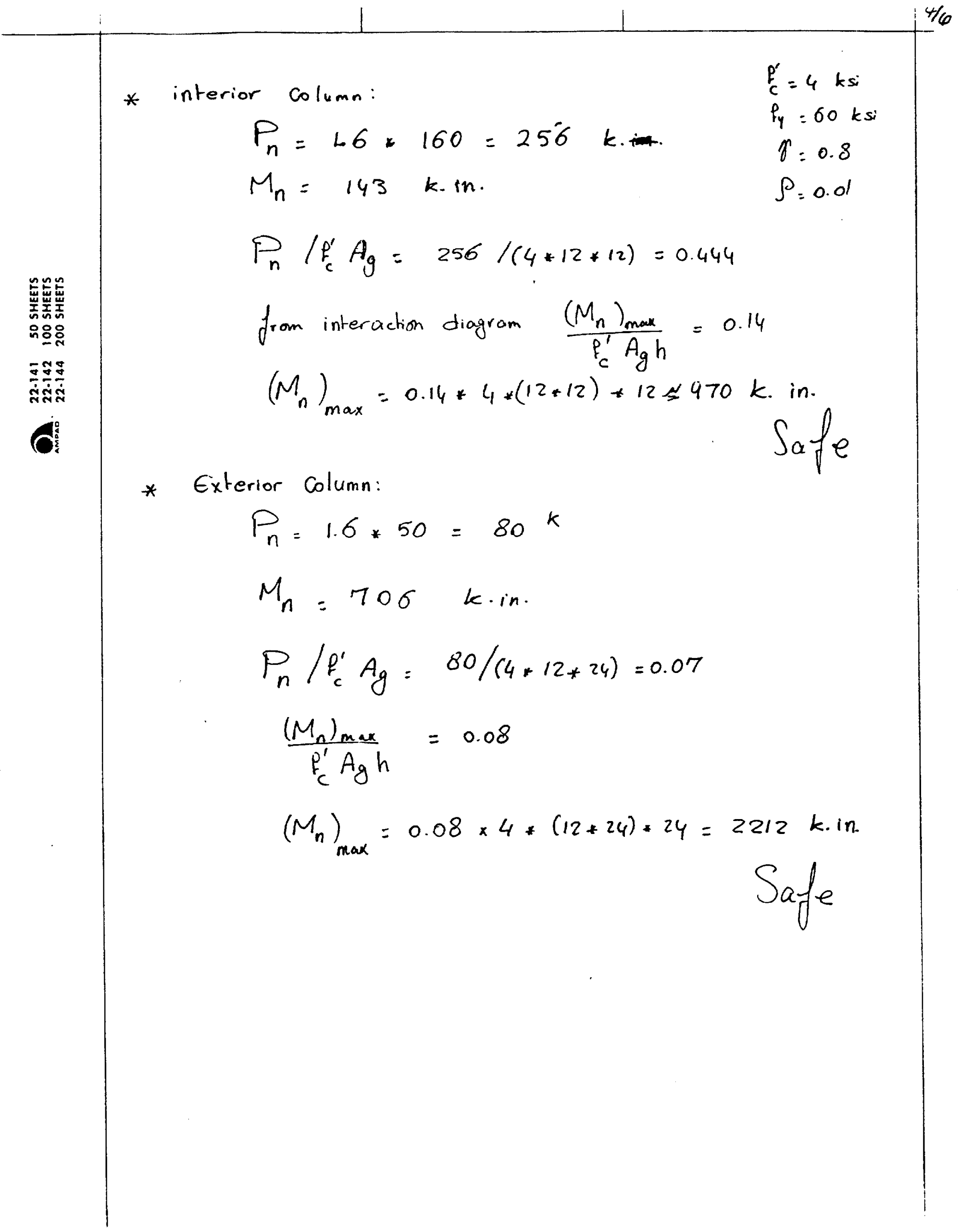




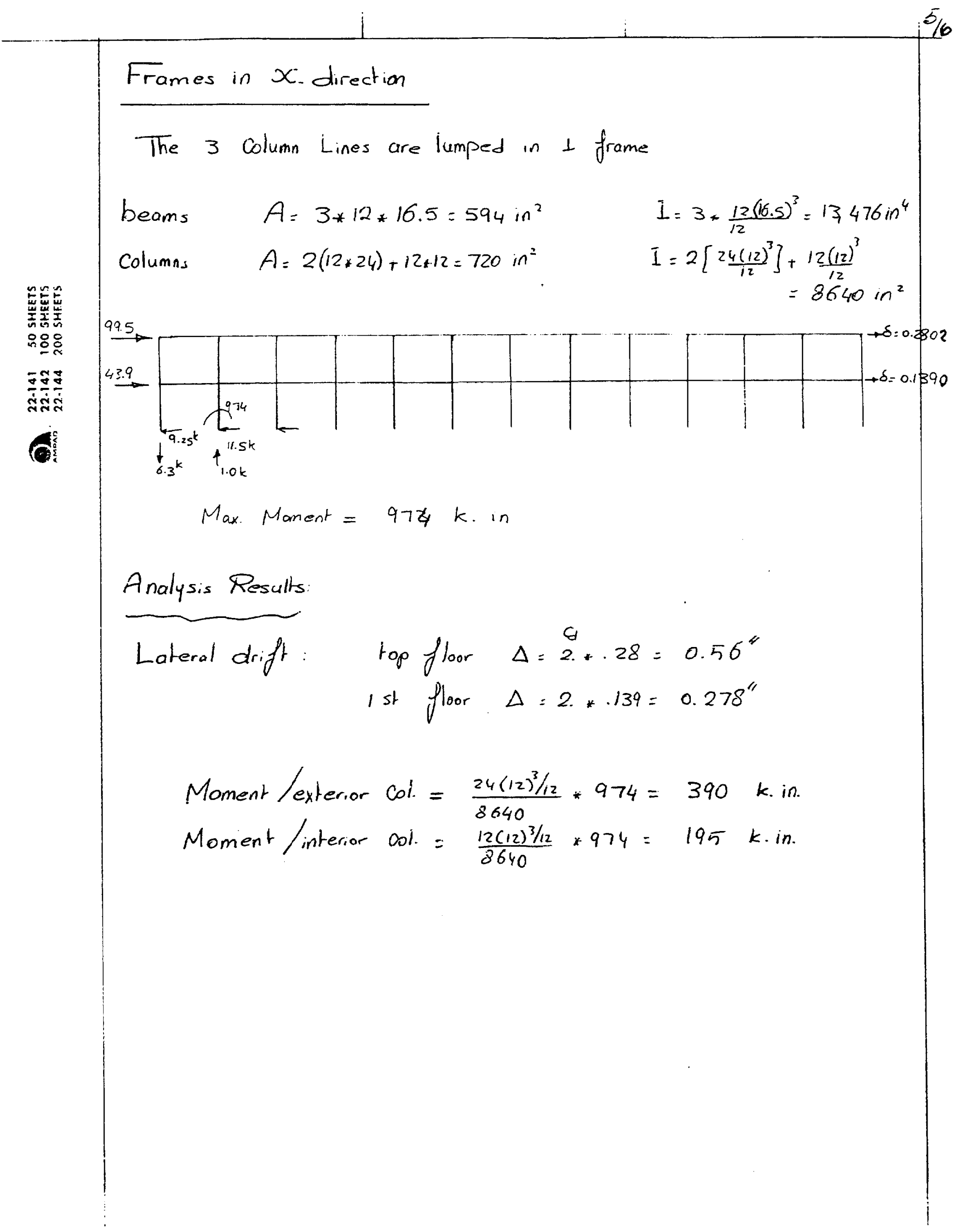




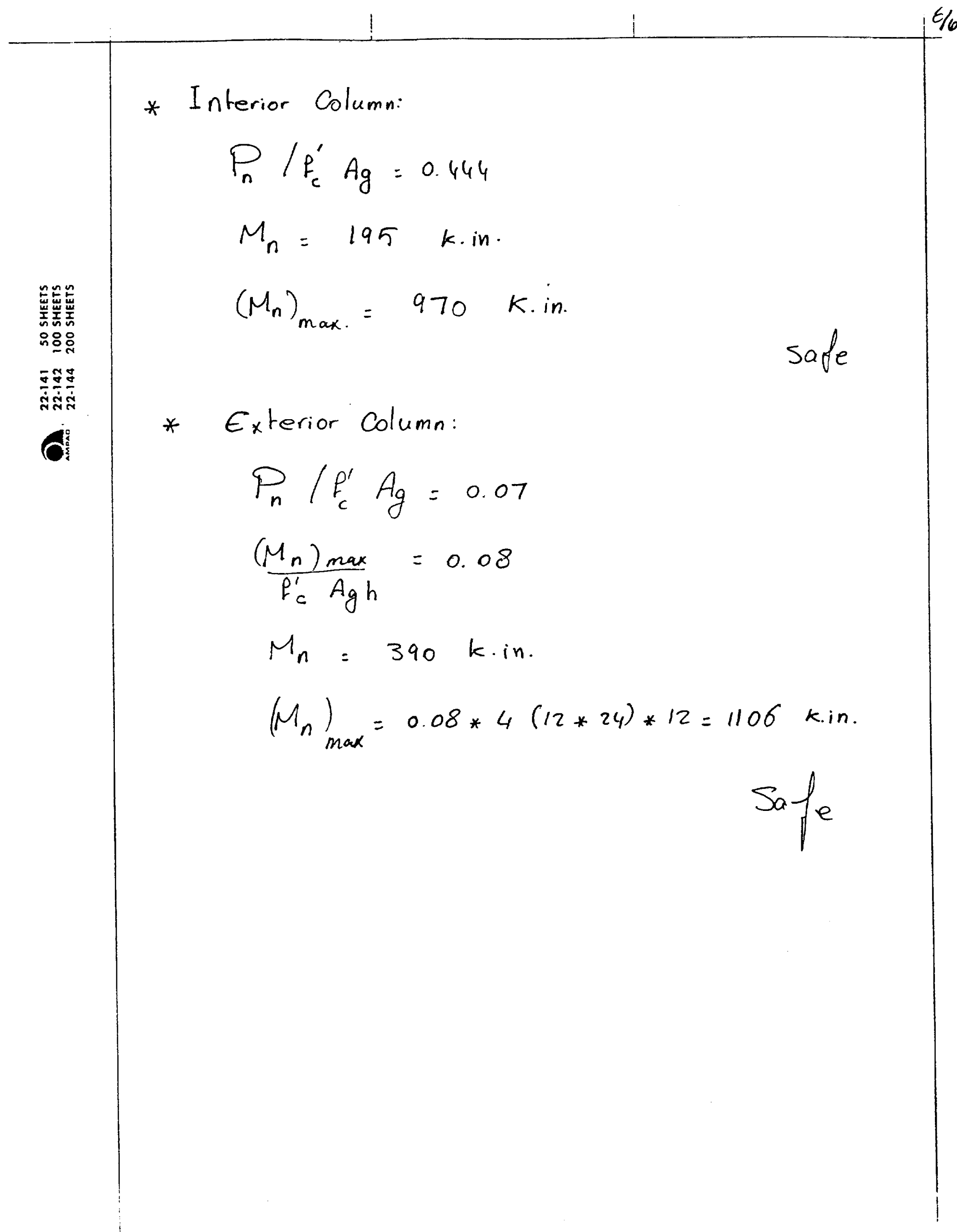


Building Designation :

$" 0 "$

Location:

Emmittsburg, MD

DATA SUMMARY SHEET

BUILDING DATA

Year built: 1839 Years) remodelled: 1970 's

Date of Evaluation: $\frac{6 / 23 / 98}{70}$ Length $124^{\prime}$ Width $68^{\prime}$ Photo Roll No.

CONSTRUCTION DATA

Rooframing: Timber Trusses

Intermediate floor framing: Timber members

Ground floor: Timber Basement: Concrete

Exterior walls:Stonemasonry Openings: Large windows

Columns: Brick Foundations: Stone masonry

General condition of structure: FAIR

Evidence of settling. Not Noticeable

LATERAL FORCE RESISTING SYSTEM

Transverse Longitudinal

Model building type:

Building period, $T$ :

Unreduced base shear,

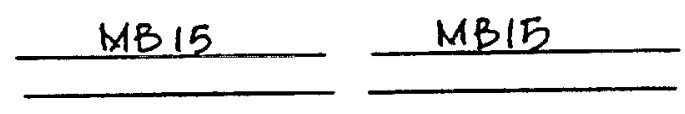

$$
V=\left[\left(0.80 A_{v} \times S\right) /\left(R \times T^{2 / 3}\right)\right] \times(W) \text { or } V=[2.12 A a / R] \times W
$$

Response Modification Coefficient, $R$ :

1.25

EVALUATION DATA

$$
A_{a}=0.05 \quad A_{v}=0.05
$$

Site soil profile type: $S_{2}$ Site soil coefficient, $S=1.2$

REMARKS

Historic resister.

Timber steeple needs a special attention. 


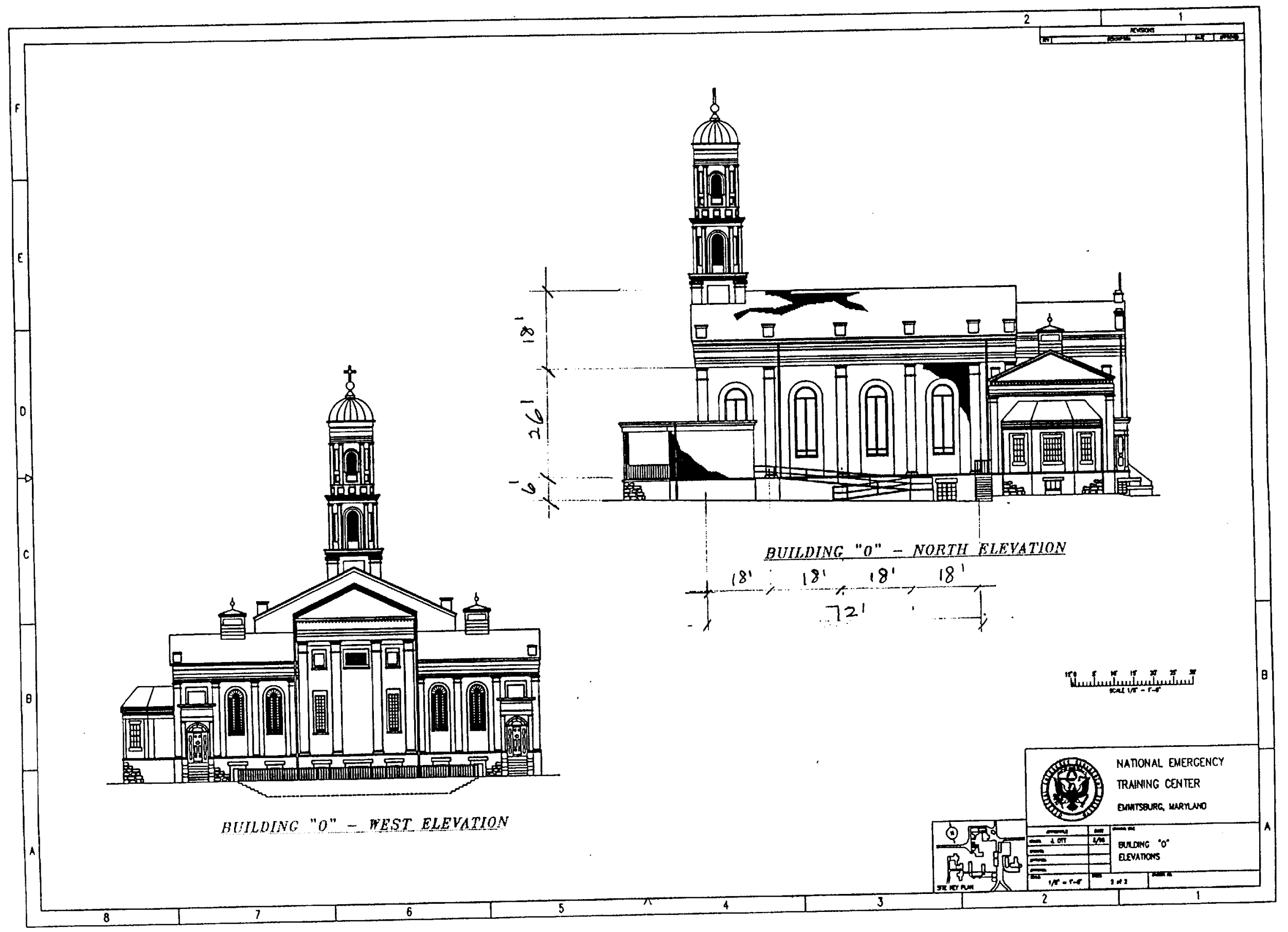




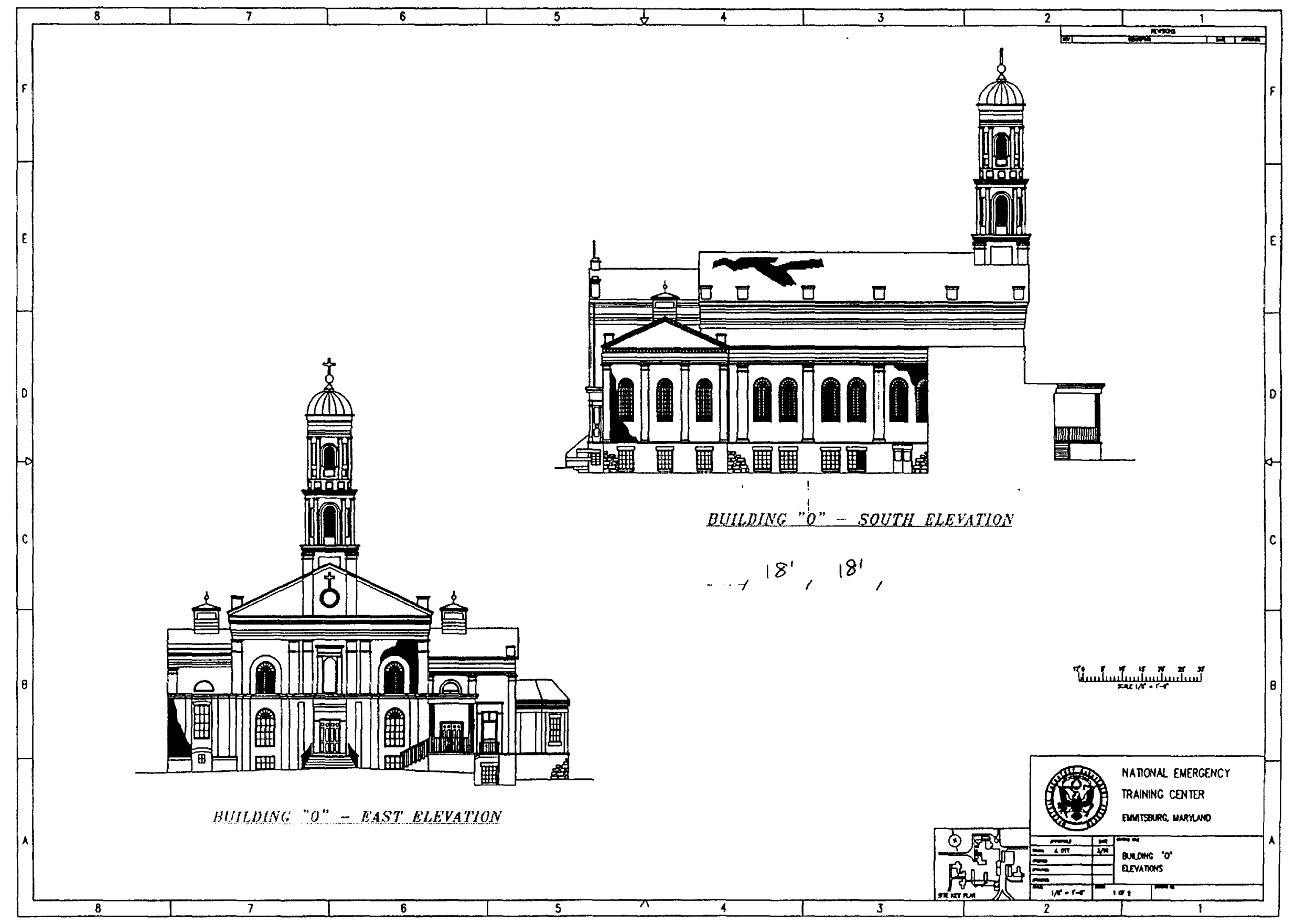




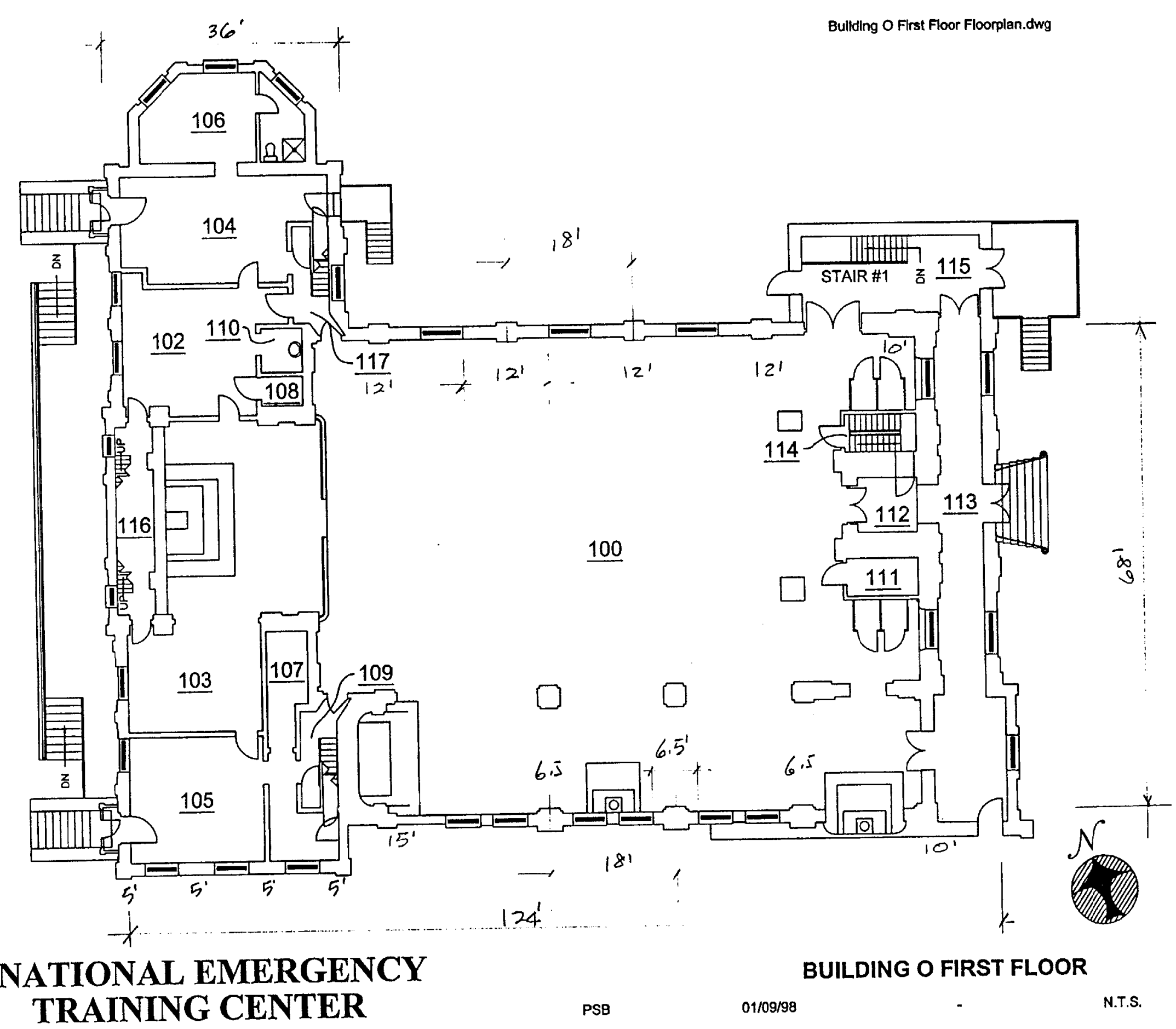




Duilding "O". Enumittsburq, MD

\section{EVALUATION STATEMENTS FOR BUILDING TYPE 15: UNREINFORCED MASONRY BEARING WALL BUILDINGS}

These buildings include structural elements that vary depending on the age of the building and, to a lesser extent, the geographic location of the structure. In buildings built before 1900, the majority of floor and roof construction consists of wood sheathing supponed by wood subframing. In large multistory buildings, the floors are cast-in-place concrele supported by the unreinforced masonry walls and/or steel or concrete interior framing. In buildings built after 1950, unreinforced masony buildings with wood floors usually have phwood rather than board sheathing. More recently, in regions of lower seismicity, these buildings can include floor and roof framing that consists of metal deck and concrete fill supported by steel framing elements. The perimeter walls, and possibly some interior walls, are unreinforced masonry. The walls may or may not be anchored to the diaphragms. Ties between the walls and diaphragms are more common for the bearing walls than for walls that are parallet to the floor framing. Roof ties usually are less common and more erratically spaced than those at the floor levels. Interior partitions that intenconnect the floors and roof can have the effect of reducing diaphragm displacements.

Address the following evaluation statements, marking each either true (T) or false (F). Statements that are found to be true identify issues that are acceptable according to the criteria of this handbook; statements that are found to be false identify issues that need investigation. For guidance in the investigation, refer to the bandbook section indicated in parentheses at the end of the statement.

Be advised that the numerical indices preceded by an asterisk $\left({ }^{*}\right)$ in these statements are based on high seismicity $\left(A_{v}=0.4\right)$. Adjustments are reasonable for lower seismicity. The appropriate adjustment is not necessarily a direct ratio of seismicity.

\section{BUILDING SYSTEMS}

$\mathbf{T} \mathbf{F}$

LOAD PATH: The structure contains a complete load path for seismic force effects from any horizontal direction that serves to transfer the inertial forces from the mass to the foundation (NOTE: Write a brief description of this linkage for each principal direction.) (Sec. 3.1) Do effective means of trausferring the steeple mass to foundation.

(T) F REDUNDANCY: The structure will remain laterally stable after the failure of any single element. (Sec. 3.2)

$\mathbf{T} \mathbf{F}$

WEAK STORY: Visual observation or a Quick Check indicates that there are no significant strength discontinuities in any of the vertical elements in the lateral-forceresisting system; the story strength at any story is not less than 80 percent of the strength of the story above. (Sec. 3.3.1) Many large window openings

(T) F SOFT STORY: Visual observation or a Quick Check indicates that there are no significant stiffness discontinuities in any of the vertical elements in the lateral-forceresisting system; the lateral stiffness of a story is not less than 70 percent of that in the story above or less than 80 percent of the average stiffness of the three stories above. (Sec. 3.3.2) 
(T) F GEOMETRY: There are no significant geometrical irregularities; there are no setbacks (i.e., no changes in horizontal dimension of the lateral-force-resisting system of more than 30 percent in a story relative to the adjacent stories). (Sec. 3.3.3)

(T) F MASS: There are no significant mass irregularities; there is no change of effective mass of more than 50 percent from one story to the next, excluding light roots. (Sec. 3.3.4)

(T) F VERTICAL DISCONTINUITIES: All shear walls are continuous to the foundation. (Sec. 3.3.5)

(T) F TORSION: The lateral force resisting elements form a well balanced system that is not subject to significant torsion. Significant torsion will be taken as any condition where the distance between the story center of rigidity and the story center of mass is greater than 20 percent of the width of the structure in either major plan dimension. (Sec. 3.3.6)

(T) F ADJACENT BUILDINGS: There is no immediately adjacent structure that is less than half as tall or has floors/levels that do not match those of the building being evaluated. A neighboring structure is considered to be "immediately adjacent" if it is within 2 inches times the number of stories away from the building being evaluated. (Sec. 3.4)

(T) F MASONRY UNITS: There is no visible deterioration of large areas of masonry units. (Sec. 3.5.10)

(T) F MASONRY JOINTS: The mortar cannot be easily scraped away from the joints by hand with a metal tool, and there are no significant areas of eroded mortar. (Sec. 3.5.9)

For buildings with wood diaphragms and unreinforced masonry bearing and enclosure walls at the perimeter, complete the evaluation using the procedure given in Appendix C. For other buildings, continue with the following evaluation statements.

\section{MASONRY WALLS}

(T) F SHEARING STRESS CHECK: The building satisfies the Quick Check of the shearing stress in the unreinforced masonry shear walls. (Sec. 5.4.1)

(T) F PROPORTIONS: In areas of high seismicity $\left(A_{v}\right.$ greater than or equal to 0.2$)$, the heightthickness "ratio of the unreinforced masonry wall panels is as follows: (Sec. 5.5.1; also see Appendix C)

- One-story building:

- Multistory building: Top story: Other stories:

$$
\begin{aligned}
& h_{w} / t<14 \\
& h_{w} / t<9 \\
& h_{w} / t<20
\end{aligned}
$$

(T) F MASONRY LAY-UP: Filled collar joints of multiwythe masonry walls have negligible voids. (Sec. 5.4.2) 


\section{DIAPHRAGMS}

(T) F PLAN IRREGULARITIES: There is significant tensile capacity at re-entrant corners or other locations of plan irregularities. (Sec. 7.1.1)

(T) F REINFORÇING AT OPENINGS: There is reinforcing around all diaphragm openings larger than 50 percent of the building width in either major plan dimension. (Sec. 7.1.3)

(T) F SPAN/DEPTH RATIO: If the span/depth ratios of wood diaphragms are greater than 3 to 1 , there are nonstructural walls connected to all diaphragm levels at less than 40 -foot spacing. (Sec. 7.2.4)

T (F) SHEATHING: None of the diaphragms consist of straight sheathing or have span/depth ratios greater than " 2 to 1 . (Sec. 7.2.1)

\section{CONNECTIONS}

$\mathbf{T}$

F MASONRY WALL ANCHORS: Wall anchorage connections are steel anchors or straps that are developed into the diaphragm. (Sec. 8.2.3) Not known

T (F) ANCHOR SPACING: The anchors from the floor and roof systems into exterior masonry walls are spaced at 4 feet or less. (Sec. 8.2.4)

Not known 
$1 / 2$

Buiding $O$ - Einmittsburg, $M D$

$7-27-98$

$A_{v}=0.1, \quad A_{c}=0.1$.

Roof straight sheating $v=300 * / f t$.

Leugth of shear wall at $1^{\text {st }}$ floor $\approx 158^{\prime}$

$$
h_{w} / t=\frac{26}{1.5}=17.3<14 \quad \text { ork } \quad \Delta_{v} \leqslant 0.1 \text {. }
$$

Bold weigut.

Botf $f^{3}$ for masoury

$$
\begin{aligned}
& 250^{\prime}+250^{\prime}+71^{\prime}+100^{\prime} \cong 670^{\prime} \text { perimetr } \\
& v_{0 l}=670^{\prime} \times 1.5^{\prime}(\text { thickuon }) \times 24^{\prime}=24120 \mathrm{ft} \\
& w(\text { mastoury })=130 \times 24120 \cong 3130 \mathrm{~K}
\end{aligned}
$$

Root: Timber... $\approx 45 * / 6$.

$$
45 \times 124 \times 68 \stackrel{380 k}{=}
$$

Ceiling: Wood.lath + plaster $\quad 20$ \#/

$20 \times 124 \times 68 \approx 170 \mathrm{k}$.

$W(\Sigma$ tead werqut $)=3130+380^{\circ}+17^{\circ}=3680^{\circ} \mathrm{K}$.

$V=C_{s} w$.

$C_{s}=\frac{2.12 A_{a}}{R} \quad$ for short period buildiugo. 
Buildug 0

$2 / 2$

$$
\begin{aligned}
& c_{s}=\frac{2.12 \times 0.1}{1.25}=0.17 \\
& V=0.17 \times 3680^{k} \cong .626 \mathrm{~K} \\
& V=\frac{626000^{*}}{34128} \cong 18 \mathrm{psi} \times 1.25=22.5 \mathrm{psi} \\
& V_{\text {in }}=\underset{\substack{\uparrow \\
\text { say do }}}{0.56 V_{w}}+\frac{0.75 P_{D}}{A}=0.56 \times 40+\frac{0.75(3680000)}{34128} \\
& =22.4+8.08=30.5 \mathrm{psi}>22.5 \mathrm{psi}
\end{aligned}
$$


Bidq "O"

OPTION 2 COST ESTIMATION FORM

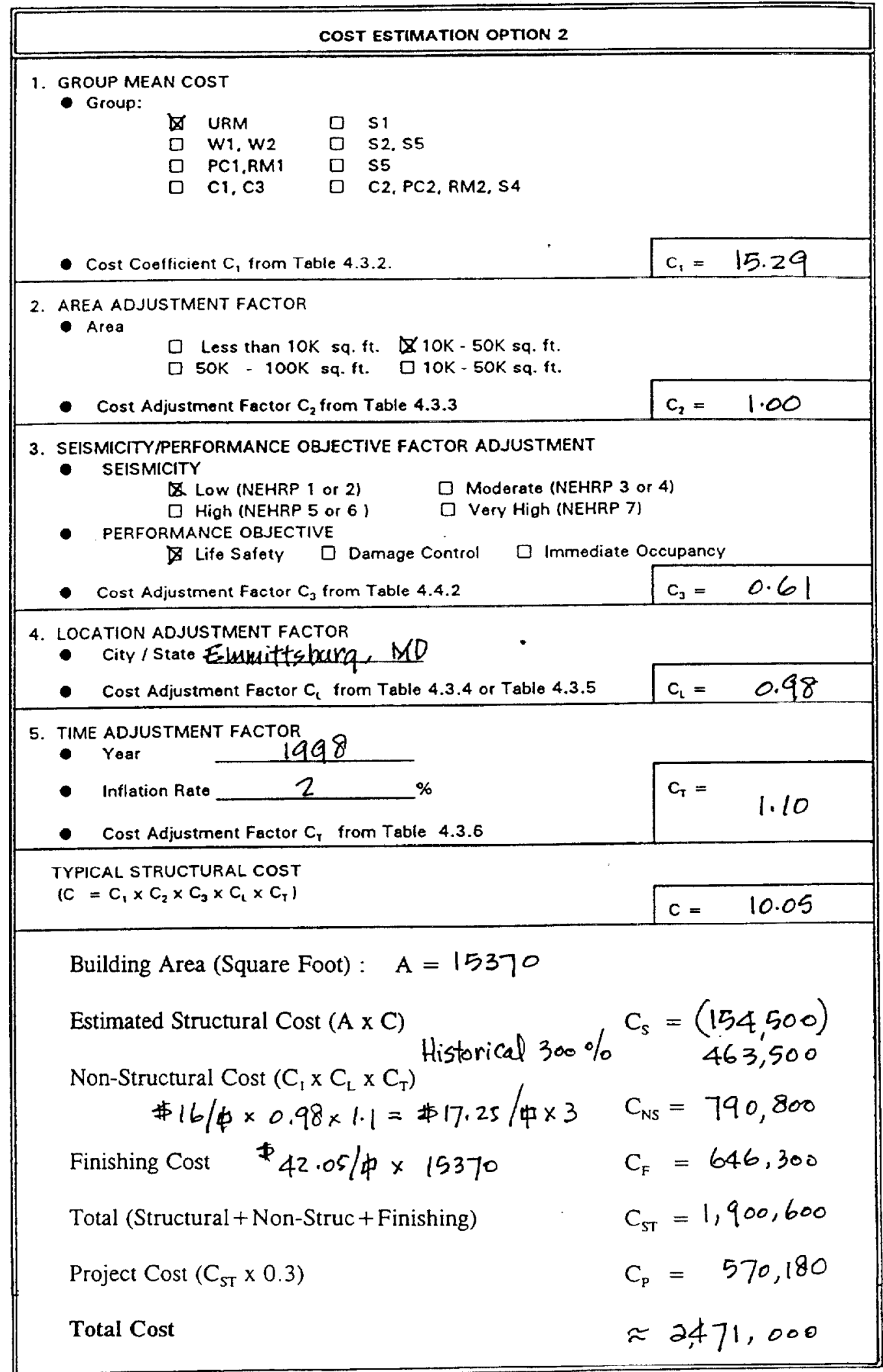


Building Designation: Maynard Federal Reqional Center Location: Maynard, MA

\section{DATA SUMMARY SHÉET}

\section{BUILDING DATA}

Year built: $1968 \quad$ Year(s) remodelled:

Date of Evaluation: $9 / 8 / 98$

Area, (sq. ft.) 80,000 Leagth $140^{\prime}$ Width $120^{\prime}$ Photo Roll No.

\section{CONSTRUCTION DATA}

Rooframing: Concrete beaus and slab Intermediatefloorframing: Conevete beaus and slab Ground floor: N/A Basement:

Exterior walls: N/A Openings:

Columns: conerete Foundations: concrete tooting

General condition of structure:

Evidence of settling: None

\section{LATERAL FORCE RESISTING SYSTEM}

\section{Transverse Longitudinal}

Model building type:

Building period, $T$ :

$M B 16-M B 16$

Unreduced base shear, $V=\left[\left(0.80 A_{v} \times S\right) /\left(R \times T^{2 / 3}\right)\right] \times(W)$ or $V=[2.12 \mathrm{Aa} / R] \times W$

Response Modification Coefficient, $R$ :

$N / A$

\section{EVALUATION DATA}

$A_{a}=0.10 \quad A_{v}=0.10$

Site soil profile type: $S_{2}$ Site soil coefficient, $S=1.2$

$\frac{\text { REMARKS }}{\text { Underground structure desigued for nuclear blast. }}$ 
Building Designation: MAYNARD VSAB

Location:

MAYNARD, MA

DATA SUMMARY SHEET

BUILDING DATA

Year built: 1988 Years) remodelled: -

Date of Evaluation: $9-8-98$

Area, (sq. f.) 40,000 Length $272^{\prime}$ Width $147^{\prime}$ Photo Roll No.

CONSTRUCTION DATA

Rooframing: metal root deck

Intermediate floor framing:

Ground floor: Con ce

Basement: None

Exterior walls: metal

Columns: steel

Openings:

General condition of structure:

Foundations: _spread tooting

Evidence of settling:

LATERAL FORCE RESISTING SYSTEM

Transverse Longitudinal

Model building type:

Building period, $T$ :

Unreduced base shear,

MHOS

$V=\left[(0.804, \times S) /\left(R \times T^{2 / 3}\right)\right] \times(W)$ or $V=[2.12 \mathrm{Aa} / R] \times W$

Response Modification Coefficient, $R$ :

$5 \cdot 5$

EVALUATION DATA

$A_{a}=0.10 \quad A_{v}=0.10$

Site soil profile type:

$S_{2}$ Site soil coefficient, $S=1.2$

REMARKS

Pre-englneeved rigid frames 


\section{mers garage Maynard, MA}

\section{EVALUATION STATEMENTS FOR BUILDING TYPE 5: STEEL LIGHT FRAME}

These buildings are pre-engineered and pre-fabricated with transverse rigid frames. The roof and walls consist of light-weight panels. The frames are designed for maximum efficiency, often with tapered beam and column sections built up of light plates. The frames are built in segments and assembled in the field with bolted joints. Lateral loads in the transverse direction are resisted by the rigid frames, with loads distributed to them by shear elements. Loads in the longitudinal direction are resisted entirely by shear elements. The shear elements can be either the roof and wall sheathing panels, an independent system of cension-onty rad bracing, or a combination of panels and bracing.

Address the following evaluation statements, marking each either true $(T)$ or false $(F)$. Statements that are found to be true identify issues that are acceptable according to the criteria of this handbook; statements that are found to be false identify issues that need investigation. For guidance in the investigation, refer to the handbook section indicated in parentheses at the end of the statement.

Be advised that the numerical indices preceded by an asterisk $\left(^{*}\right)$ in these statements are based on high seismicity $\left(A_{v}=0.4\right)$. Adjustments are reasonable for lower seismicity. The appropriate adjustment is not necessarily a direct ratio of seismicity.

\section{BUILDING SYSTEMS}

F LOAD PATH: The structure contains a complete load path for seismic force effects from any horizontal direction that serves to transfer the inertial forces from the mass to the foundation (NOTE: Write a brief description of this linkage for each principal direction.) (Sec. 3.1)

F REDUNDANCY: The structure will remain laterally stable after the failure of any single element. (Sec. 3.2)

(T) F WEAK STORY: Visual observation or a Quick Check indicates that there are no significant strength discontinuities in any of the vertical elements in the lateral-forceresisting system; the story strength at any story is not less than 80 percent of the strength of the story above. (Sec. 3.3.1)

(T) F SOFT STORY: Visual observation or a Quick Check indicates that there are no significant stiffness discontinuities in any of the vertical elements in the lateral-forceresisting system; the lateral stiffness of a story is not less than 70 percent of that in the story above or less than 80 percent of the average stiffness of the three stories above. (Sec. 3.3.2)

T F TORSION: The lateral force resisting elements form a well balanced system that is not subject to significant torsion. Significant torsion will be taken as any condition where the distance between the story center of rigidity and the story center of mass is greater than 20 percent of the width of the structure in either major plan dimension. (Sec. 3.3.6) 
(T) F DETERIORATION OF STEEL: There is no significant visible rusting, corrosion, or other deterioration in any of the steel elements in the vertical or lateral-force-resisting systems. (Sec. 3.5.3)

\section{MOMENT FRAMES}

(T) F STRESS CHECK: The building satisfies the Quick Check of the stress in the diagonals. (Sec. 6.1.1)

(T) F BEAM PENETRATIONS: All openings in frame-beam webs have a deptb less that $1 / 4$ of the beam depth and are located in the center balf of the beams. (Sec. 4.2.3)

\section{DLAPHRAGMS}

(T) F PLAN IRREGULARITIES: There is significant tensile capacity at re-entrant comers or other locations of plan irregularities. (Sec. 7.1.1)

(T) F REINFORC̣ING AT OPENINGS: There is teinforcing around all diaphragm openings larger than " 50 percent of the building width in either major plan dimension. (Sec. 7.1.3)

\section{CONNECTIONS}

(T) F STEEL COLUMNS: The columns in the lateral-force-resisting system are substantially anchored to the building foundation. (Sec. 8.4.1)

\section{WALL AND ROOF PANELS}

(T) F LIGHT-GAGE METAL, PLASTIC, OR CEMENTITIOUS ROOF PANELS: All lightgage metal, plastic, or cementitious roof panels are properly connected to the roof framing at not more than 12 inches on center. (Sec. 8.6.1)

(T) F WALL PANELS: All wall panels (metal, fiberglass, or cement asbestos) are properly connected to the framing. (Sec. 8.6.2) 
MaRs Garage I Maynard, ma

$1 / 4$

original Desiqu Loads

$$
\begin{aligned}
& \text { Wind }=90 \mathrm{mph} \\
& \text { snow }=35 \text { psf } \\
& L_{1} L \text {. (office) }=80 \text { psf. }
\end{aligned}
$$

Weight of Building.

Roofing (metal deck + insulation)
Purlin
Roof wright $=4.5 \times 39600=$
snow $=35 \times 39600=$
suspended Ceiling us office areas.

$$
1 \text { pst } \times 9000=9 \text { kips per floor. }
$$

$2^{\text {nd }}$ fl slab (4 "conc)

$$
48.3 \text { pst } \times 9000=435 \text { kips. }
$$

Interior wall s

$$
55 \text { pst } \times 120 \times 26.5^{\prime}=175 \text { kips. }
$$

Interior partitions

$$
\begin{aligned}
& 1^{\text {st }} \mathrm{fl}^{\prime}: \mathrm{CMU} 55 \times 11^{\prime} \times 630^{\prime}=381 \mathrm{kips} \\
& \text { metal Stud } 4.5 \times 11 \times 185=92 \\
& 2^{\text {nd }} \mathrm{fl}: \text { CU } \pi 5 \times 15 \times 350=289 \mathrm{kips} \\
& \text { iSP } 4.5 \times 8 \times 510=18.4
\end{aligned}
$$

and fo steel training: 70.5 kips. 
Hers garage : Maynard, Ma

Exterior walls

NORTH Col 1 thru 7

CHG 2.1 .8 kips.

Steel 24.0

Doors 23.0

col 7 then 10 che 167 kips.

South

Col 1 thru 5

CML

214

steel 14.5 kips

Doors 15.4

Co 1 5 thru 8 CML 10.9 kips

$\begin{array}{ll}\text { Steel } & 7.5 \\ \text { Doors } & 11.5\end{array}$

Col 8 then 10

CML 124.6 kips

EAST

Col A thru E Crus 375 kips

col E then G CMU $\begin{array}{rrr}36.3 & \text { kips } \\ \text { Steel } & 7.4 & \end{array}$

WEST

$\begin{array}{ll}\text { CMl } & 109 \text { kips } \\ \text { steel } & 27.9\end{array}$

Pre-engineered steel frames: $143 \mathrm{kips}$ 


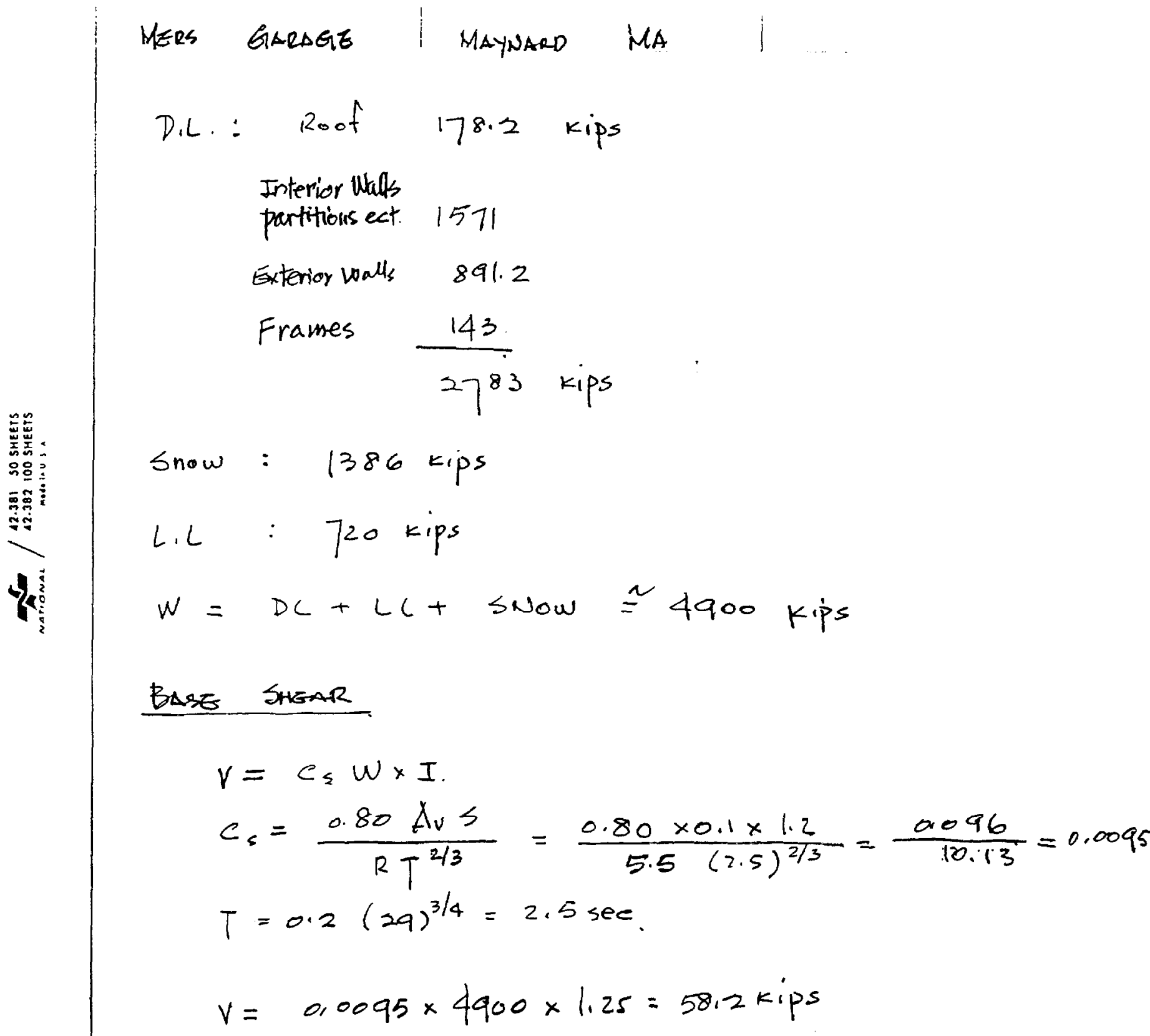

Assume All shear is carried by Masonry walls

$$
\begin{aligned}
& f_{m}^{\prime}=3000 \text { psi } \\
& E_{s}=29000 \mathrm{ksi} \\
& E_{m}=2250 \\
& n=12.9 \\
& \# 4 e 2^{\prime}-8^{\prime \prime} \circ c \\
& \rho=0.2 / 32 \times 8=0.00078 \text { o.k use } 2106.1 \\
& k=0.132
\end{aligned}
$$

$3 / 4$ 
Mars garage I maynard ma

$4 / 4$

$$
\begin{aligned}
& i=1-\frac{0.132}{3}=0.956 \\
& b=8^{\prime \prime}, \quad d=48^{\circ} \\
& f_{J}=\frac{V}{b_{j d}}
\end{aligned}
$$

About $60 \%$ of the base shear is carried by a

BASE O on tributary areas shorter wall.

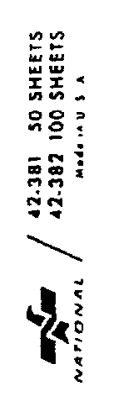

$$
\begin{aligned}
& v=0.6 \times 58.2 \\
& f_{v}=\frac{0.6 \times 58.2}{8(0.956)(48 \times 12)}=7.9 \mathrm{psi}
\end{aligned}
$$

FETA $310 \quad 3.5 .3 .3$

$$
\begin{aligned}
V & =\frac{1}{m}\left(\frac{V}{\Delta_{\omega}}\right) . \\
& =\frac{1}{3.0}\left(\frac{58.2 \mathrm{~K}}{8 \times 60 \times 12 \times 75 \%}\right)=4.5 \mathrm{psi}
\end{aligned}
$$

oik. for shear wall

ChEck SHEar Transfer to the west direction

Roof

$$
\begin{array}{r}
3.5 \times(180 \times 120+60 \times 120) \\
28800
\end{array}=100,8 \mathrm{kps}
$$

snow $35 \times 28800=1008 \mathrm{kips}$

wall $N(21.8+24+23) \frac{1}{2}=34.4$

$$
\begin{aligned}
(14.5+4.9+15.4) \frac{1}{2} & =17.4 \\
(19.9 \times 2) \frac{1}{2} & =\frac{19.9}{1180.5 \mathrm{kip}}
\end{aligned}
$$

Total cross section of Z's

$$
\begin{aligned}
& 24 \times 0.706=16.940^{11} \\
& f=\frac{1180.5}{16.94}=69.7 \mathrm{ksi}>36 \mathrm{ksi}
\end{aligned}
$$

Not adequate to transfer tension due to lateral movement in the E-w direct. 


$$
\text { Maynard VSAB }
$$

OPTION 2 COST ESTIMATION FORM

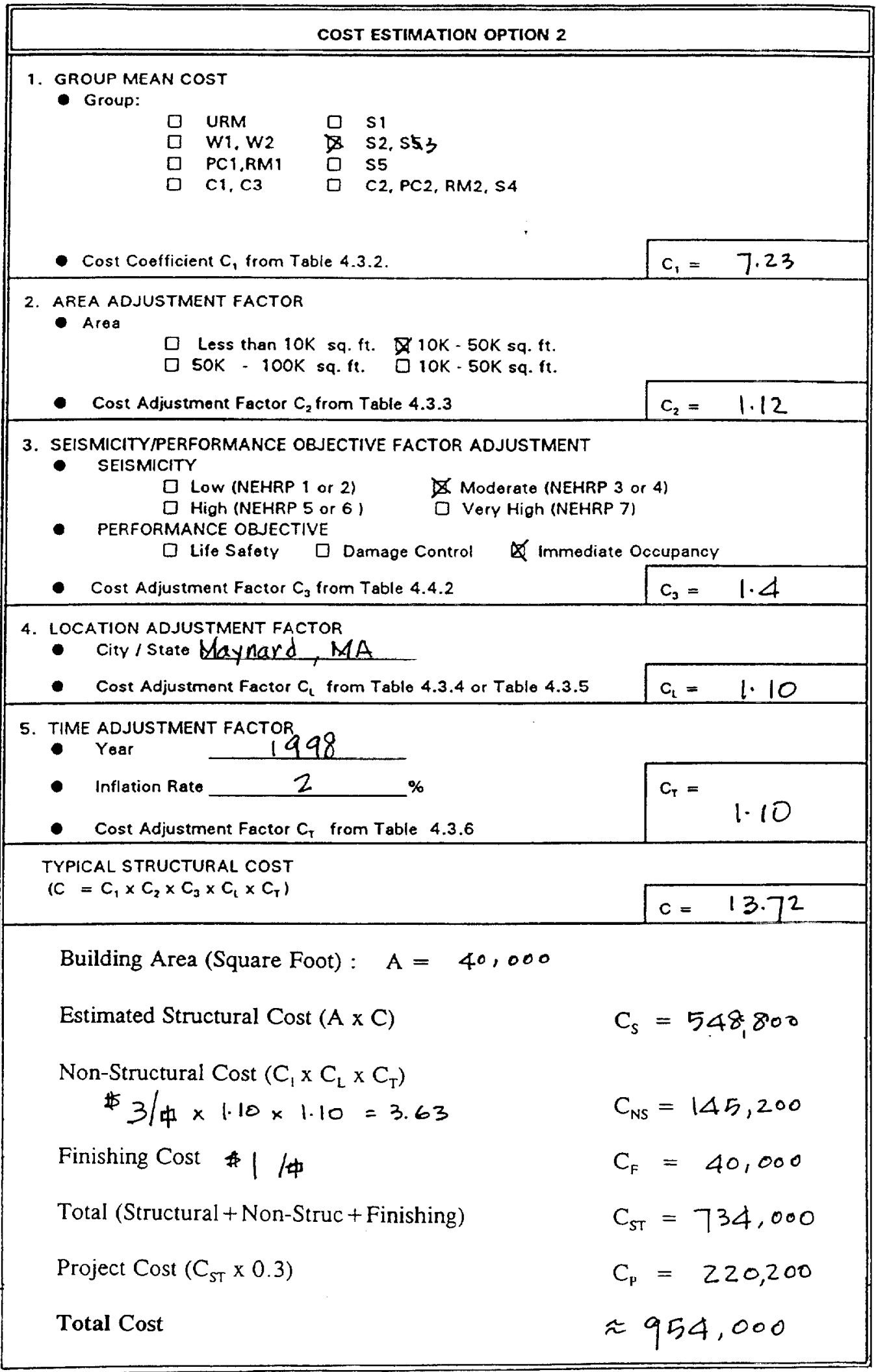


Attachment C: Building Inventory and Rehabilitation Cost Database 


\begin{tabular}{|c|c|c|c|c|c|c|c|c|c|c|c|}
\hline Kog $10 \%$ & 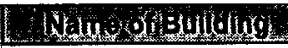 & $\sec 0$ & $b_{3} y_{3}$ & Sifonitel & A1) & 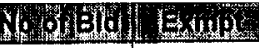 & 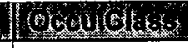 & Fos & 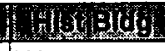 & 10 c1000 & 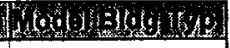 \\
\hline 5800 & Boathouse & 24 & 021 & $\mathrm{~L}$ & 46 & 1 E1 & 80 & $\mathrm{Z2}$ & $\mathrm{H} 2$ & 1960 & MB13 \\
\hline 5800 & Bothell VSAB & 53 & 061 & $\mathbf{H}$ & 2,787 & EO & 50 & 21 & $\mathrm{H} 2$ & 1985 & MB05 \\
\hline 5800 & Building 104 & 51 & 107 & $\mathrm{~L}$ & 1,014 & 1)EO & 40 & 22 & $\mathrm{H}_{2}$ & 1955 & MB16 \\
\hline 5800 & Building 105 & 51 & 107 & $L$ & 936 & 1 EO & 10 & $Z 2$ & $\mathrm{H} 2$ & 1955 & MB15 \\
\hline 5800 & Building 106 & 51 & 107 & $L$ & 347 & E1 & 40 & 22 & $\mathrm{H} 2$ & 1955 & $\mathrm{MB16}$ \\
\hline 5800 & Bullding 110 & 51 & 107 & L & 1,292 & $1 E 0$ & 10 & 22 & $\mathrm{H} 2$ & 1955 & $M B 15$ \\
\hline 5800 & Building 114 & 51 & 107 & $L$ & 1,398 & 1 EO & 10 & 22 & $\mathrm{H} 2$ & 1955 & MB15 \\
\hline 5800 & Building 123 & 51 & 107 & $\mathrm{~L}$ & 22 & 1 EO & 80 & $Z 2$ & $\mathrm{H} 2$ & 1955 & MB15 \\
\hline 5800 & Building 127 & 51 & 107 & $L$ & 24 & 1 E0 & 60 & 22 & $\mathrm{H} 2$ & 1955 & MB16 \\
\hline 5800 & Building 140 & 51 & 107 & L & 75 & $1 \mathrm{EO}$ & 50 & $\mathrm{Z2}$ & $\mathrm{H} 2$ & 1955 & $\mathrm{MB13}$ \\
\hline 5800 & Building 146 & 51 & 107 & $L$ & 28 & $1 \mathrm{E} 1$ & 40 & $Z 2$ & $\mathrm{H} 2$ & 1955 & MB15 \\
\hline 5800 & Building 201 & 51 & 107 & $\mathrm{~L}$ & 691 & $1 E 1$ & 40 & 22 & $\mathrm{H} 2$ & 1985 & MB05 \\
\hline 5800 & Building $205 / 211 / 230$ & 51 & 107 & $L$ & 2,464 & 3 EO & 30 & $\mathrm{Zz}$ & $\mathrm{H} 2$ & 1955 & MB15 \\
\hline 5800 & Building 217 & 51 & 107 & $L$ & 821 & $1 E 0$ & 10 & $\mathrm{Z2}$ & $\mathrm{H} 2$ & 1955 & MB15 \\
\hline 5800 & Building 218 & 51 & 107 & $L$ & 874 & $1 \mathrm{EO}$ & 80 & $Z 2$ & $\mathrm{H} 2$ & 1986 & MB13 \\
\hline 5800 & Building 219 & 51 & 107 & $L$ & 348 & $1 \mathrm{EO}$ & 10 & $\mathrm{Z2}$ & $\mathrm{H2}$ & 1989 & MB05 \\
\hline 5800 & Building 219A & 51 & 107 & $L$ & 678 & $1 E 0$ & 10 & 22 & $\mathrm{H} 2$ & 1993 & MB05 \\
\hline 5800 & Building 310 & 51 & 107 & L & 440 & 1 E0 & 60 & 22 & $\mathrm{H} 2$ & 1955 & MB15 \\
\hline 5800 & Building 311 & 51 & 107 & $L$ & 33 & 1 EO & 50 & $\mathrm{Z1}$ & $\mathrm{H} 2$ & 1955 & MB15 \\
\hline 5800 & Building $312 / 313$ & 51 & 107 & L & 35 & $2 \mathrm{E1}$ & 40 & 22 & $\mathrm{H} 2$ & 1955 & MB15 \\
\hline 5800 & Building 315 & 51 & 107 & $L$ & 344 & 1 EO & 50 & $Z 2$ & $\mathrm{H} 2$ & 1955 & MB15 \\
\hline 5800 & Building 317 & 51 & 107 & $L$ & 42 & 1 E1 & 40 & $\mathrm{Z2}$ & $\mathrm{H} 2$ & 1955 & MB15 \\
\hline 5800 & Building 320 & 51 & 107 & $L$ & 346 & $1 E 1$ & 40 & $Z 2$ & $\mathrm{H} 2$ & 1955 & MB15 \\
\hline 5800 & Building 320A & 51 & 107 & L & 302 & $1 \mid E 0$ & 50 & $\mathrm{Z2}$ & $\mathrm{H} 2$ & 1988 & MB05 \\
\hline 5800 & Building 321 & 51 & 107 & $L$ & 22 & \begin{tabular}{l|l|l|}
1 & $E 1$ \\
\end{tabular} & 40 & 22 & $\mathrm{H} 2$ & 1995 & MB14 \\
\hline 5800 & Building 327 & 51 & 107 & $L$ & 190 & \begin{tabular}{l|l|}
1 & $\mathrm{E} 1$ \\
\end{tabular} & 40 & $z 2$ & $\mathrm{H} 2$ & 1955 & MB01 \\
\hline 5800 & Building 329 & 51 & 107 & $L$ & 669 & 1 EO & 40 & 22 & $\mathrm{H} 2$ & 1955 & $\mathrm{MBO5}$ \\
\hline 5800 & Building 331 & 51 & 107 & $L$ & 161 & 1 EO & 50 & 21 & $\mathrm{H} 2$ & 1955 & MB15 \\
\hline 5800 & Building 400 & 51 & 043 & $\mathrm{~L}$ & 96 & $1 \mid E O$ & 10 & $\mathrm{Z2}$ & $\mathrm{H} 2$ & 1955 & MB15 \\
\hline 5800 & Building 401 & 51 & 043 & $L$ & 65 & \begin{tabular}{l|l|}
1 & EO \\
\end{tabular} & 60 & 22 & $\mathrm{H} 2$ & 1975 & MB13 \\
\hline 5800 & Building 403 & 51 & 043 & $\mathrm{~L}$ & 358 & $1 \mathrm{EO}$ & 10 & 22 & $\mathrm{H}_{2}$ & 1955 & MB15 \\
\hline 5800 & Building 404 & 51 & 049 & L & 11 & $1 \mathrm{EO}$ & 50 & 22 & $\mathrm{H} 2$ & 1974 & MB15 \\
\hline 5800 & Building 405 & 51 & 107 & L & 929 & 1EO & 10 & $z 2$ & $\mathrm{H} 2$ & 1900 & MB01 \\
\hline 5800 & Building 406 & 51 & 107 & $L$ & 394 & $1 \mid E 0$ & 80 & 22 & $\mathrm{H} 2$ & 1974 & $\mathrm{MB01}$ \\
\hline 5800 & Building 408 & 51 & 043 & $L$ & 462 & $1 E 0$ & 50 & $z 2$ & $\mathrm{H} 2$ & 1955 & MB05 \\
\hline 5800 & Building 409 & 51 & 107 & $L$ & 779 & $1 E 0$ & 10 & 22 & $\mathrm{H} 2$ & 1974 & $\mathrm{MBO5}$ \\
\hline 5800 & Building 410 & 51 & 043 & $L$ & 568 & $1 \mathrm{EO}$ & 50 & $\mathrm{Z2}$ & $\mathrm{H} 2$ & 1900 & MB01 \\
\hline 5800 & Building 411 & 51 & 107 & $L$ & 819 & 1]EO & 10 & 22 & $\mathrm{H} 2$ & 1974 & MB05 \\
\hline
\end{tabular}




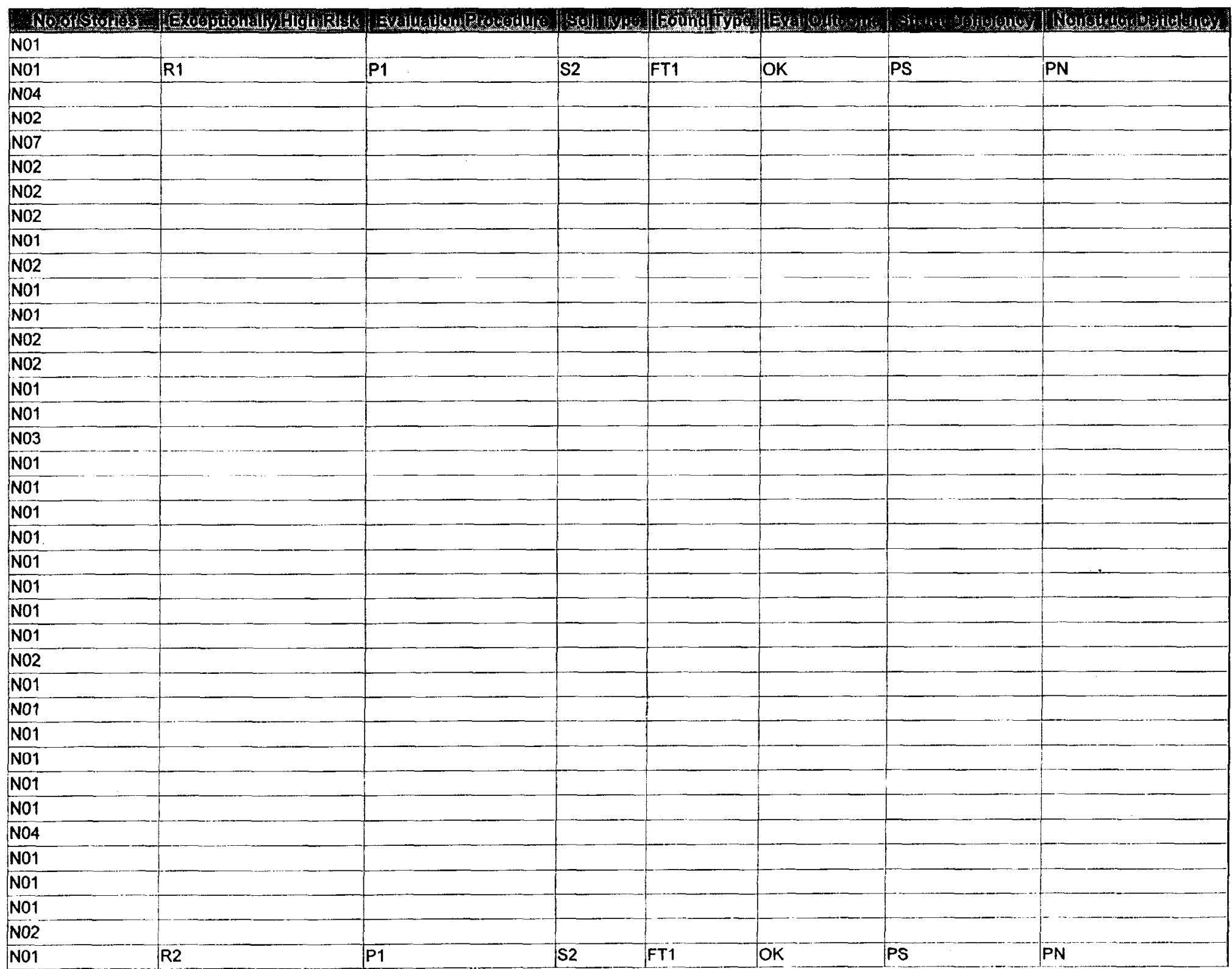




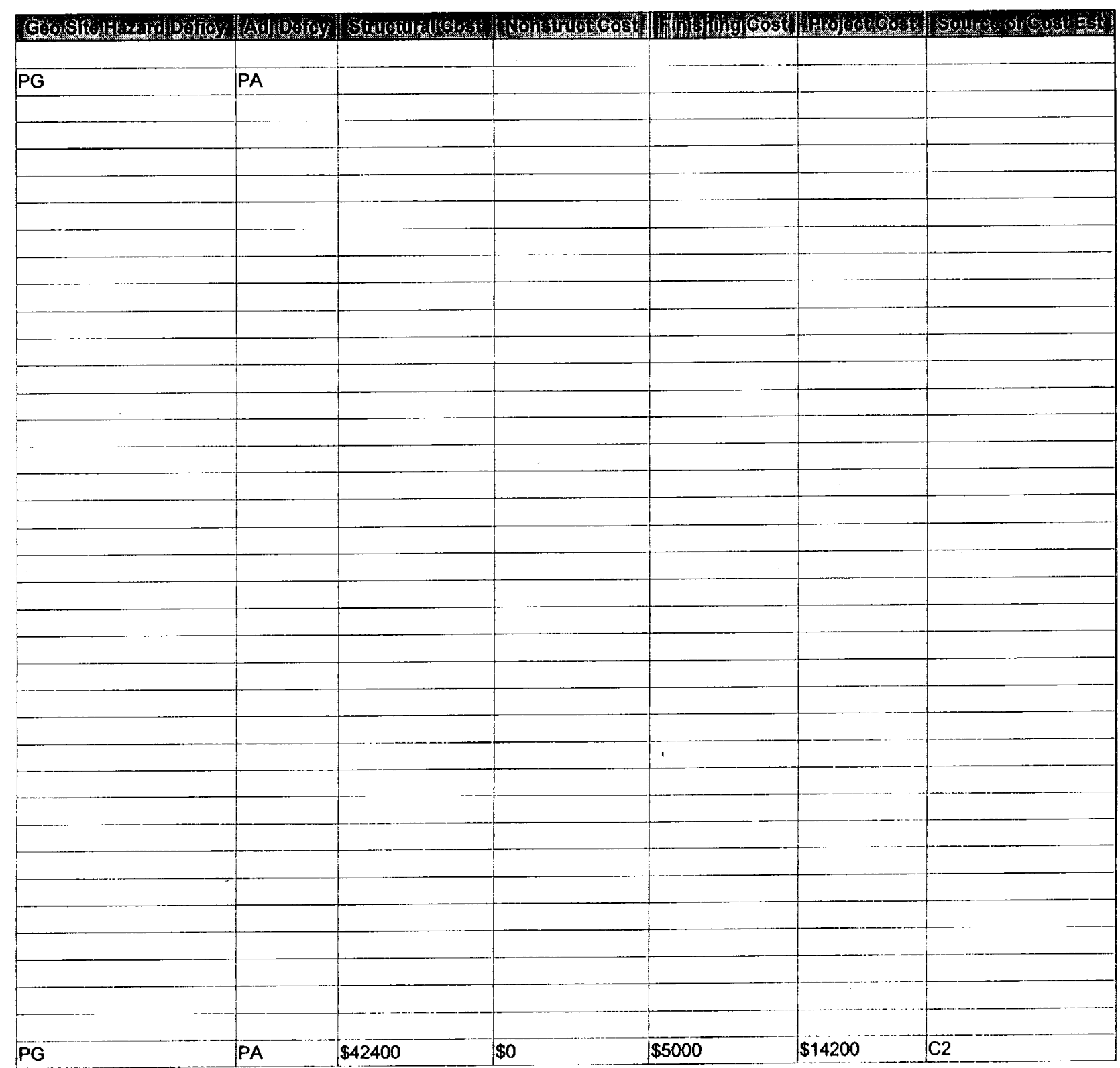

Page 3 


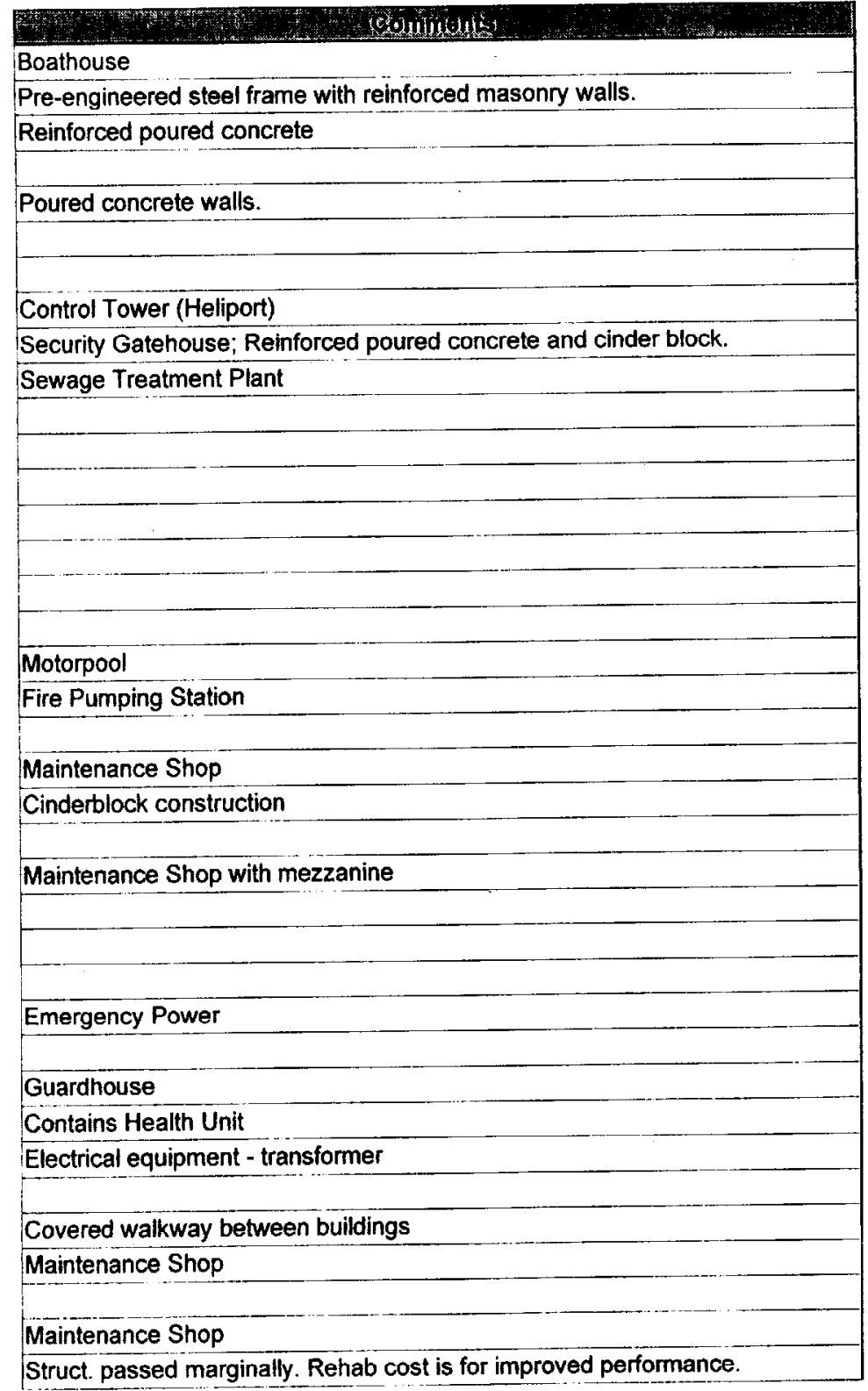




\begin{tabular}{|c|c|c|c|c|c|c|c|c|c|c|c|}
\hline Xod o & Naw on crotolng & Iffow & Gy, & 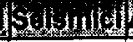 & Wothon & 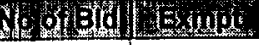 & OH.WONL & E-2id) 5164 & Ato B & 19orosio & 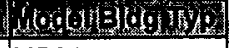 \\
\hline 5800 & Building 413 & 51 & 107 & $L$ & 1,104 & $1 E 0$ & 10 & 22 & $\mathrm{H} 2$ & 1900 & MB01 \\
\hline 5800 & Building 415 & 51 & 107 & L & 132 & $1 E 1$ & 50 & 22 & $\mathrm{H} 2$ & 1955 & MB15 \\
\hline 5800 & Building 417/425 & 51 & 107 & $L$ & 57 & $2 E 1$ & 60 & 22 & $\mathrm{H} 2$ & 1955 & MB12 \\
\hline 5800 & Building 418 & 51 & 107 & $L$ & 4 & $1 E 1$ & 60 & $\mathrm{Z2}$ & $\mathrm{H} 2$ & 1955 & MB15 \\
\hline 5800 & Building 420 & 51 & 107 & $L$ & 703 & $1 \mathrm{EO}$ & 60 & Z1 & $\mathrm{H}_{2}$ & 1955 & MB15 \\
\hline 5800 & Building 426 & 51 & 107 & $L$ & 202 & $1 E 1$ & 40 & $z 2$ & $\mathrm{H} 2$ & 1955 & MB13 \\
\hline 5800 & Building 429 & 51 & 107 & L & 1,468 & $1 \mathrm{EO}$ & 10 & 22 & $\mathrm{H} 2$ & 1955 & MB15 \\
\hline 5800 & Building 430 & 51 & 107 & $L$ & 1,336 & $1 \mathrm{E0}$ & 10 & 22 & $\mathrm{H} 2$ & 1955 & MB15 \\
\hline 5800 & Building 430A & 51 & 107 & L & 1,778 & 1|E5 & 10 & 22 & $\mathrm{H} 2$ & 1990 & MB13 \\
\hline 5800 & Building 431 & 51 & 107 & $L$ & 1,517 & $1 \mathrm{EO}$ & 10 & $\mathrm{Z2}$ & $\mathrm{H} 2$ & 1974 & MB15 \\
\hline 5800 & Building $431 \mathrm{~A}$ & 51 & 107 & $L$ & 90 & 1 EO & 10 & 22 & $\mathrm{H} 2$ & 1974 & $\mathrm{MBO4}$ \\
\hline 5800 & Building 435 & 51 & 107 & $L$ & 2,585 & 1 EO & 60 & 22 & $\mathrm{H} 2$ & 1955 & MB15 \\
\hline 5800 & Building 444 & 51 & 107 & $L$ & 3,826 & $1 E 0$ & 10 & $\mathrm{z} 2$ & $\mathrm{H} 2$ & 1990 & MB04 \\
\hline 5800 & Building 500 & 51 & 043 & $L$ & 39 & $1 E 0$ & 80 & 22 & $\mathrm{H} 2$ & 1960 & MB15 \\
\hline 5800 & Building 501 & 51 & 043 & $L$ & 5 & 1 EO & 60 & 22 & $\mathrm{H} 2$ & 1972 & MB15 \\
\hline 5800 & Building 505 & 51 & 043 & $L$ & 14 & $1 \mathrm{E} 1$ & 80 & 22 & $\mathrm{H} 2$ & 1992 & MBO1 \\
\hline 5800 & Building 604 & 51 & 043 & $L$ & 5,626 & 1 EO & 10 & 22 & $\mathrm{H} 2$ & 1986 & MBO4 \\
\hline 5800 & Building 701 & 51 & 043 & $L$ & 347 & $1 \mathrm{E1}$ & 40 & 22 & $\mathrm{H} 2$ & 1955 & MB16 \\
\hline 5800 & Building 702 & 51 & 043 & $L$ & 1,014 & E1 & 40 & 22 & $\mathrm{H} 2$ & 1955 & MB16 \\
\hline 5800 & Building 703 & 51 & 043 & $L$ & 109 & 1 E1 & 40 & $\mathrm{Z2}$ & $\mathrm{H} 2$ & 1955 & $\mathrm{MB01}$ \\
\hline 5800 & Building 704 & 51 & 043 & $L$ & 1,848 & 1EO & 10 & 22 & $\mathrm{H} 2$ & 1955 & MB15 \\
\hline 5800 & Building 706 & 51 & 043 & $L$ & 392 & $1 E 0$ & 80 & 22 & $\mathrm{H} 2$ & 1990 & MB15 \\
\hline 5800 & Building 707 & 51 & 043 & $L$ & 749 & $1 \mathrm{E1}$ & 40 & 22 & $\mathrm{H} 2$ & 1990 & MB01 \\
\hline 5800 & Building 708 & 51 & 043 & $\mathrm{~L}$ & 1,046 & 1) EO & 10 & 22 & $\mathrm{H} 2$ & 1955 & MB15 \\
\hline 5800 & Building 709 & 51 & 043 & $L$ & 86 & 1)E0 & 50 & 22 & $\mathrm{H} 2$ & 1987 & MB15 \\
\hline 5800 & Building 710 & 51 & 043 & $L$ & 114 & 1]E1 & 80 & 22 & $\mathrm{H} 2$ & 1989 & MB15 \\
\hline 5800 & Building 712 & 51 & 043 & $L$ & 1,778 & 1 EO & 10 & 22 & $\mathrm{H} 2$ & 1955 & MB15 \\
\hline 5800 & Building 713 & 51 & 043 & $L$ & 88 & $1 \mathrm{E} 1$ & 40 & 22 & $\mathrm{H} 2$ & 1992 & MB08 \\
\hline 5800 & Building 713A & 51 & 043 & $L$ & 131 & $1 E 1$ & 40 & $\mathrm{Z2}$ & $\mathrm{H} 2$ & 1993 & $\mathrm{MB} 01$ \\
\hline 5800 & Building 718 & 51 & 043 & $L$ & 25 & 1 EO & 50 & $Z 2$ & $\mathrm{H} 2$ & 1955 & MB15 \\
\hline 5800 & Building 720 & 51 & 043 & $L$ & 492 & $1 E 0$ & 50 & 22 & $\mathrm{H} 2$ & 1955 & MB08 \\
\hline 5800 & Building $721+$ & 51 & 043 & $L$ & 8,424 & 9 EO & 30 & 22 & $\mathrm{H} 2$ & 1955 & MB15 \\
\hline 5800 & Building 752 & 51 & 043 & $L$ & 24 & $1 E 0$ & 60 & 22 & $\mathrm{H} 2$ & 1955 & MB16 \\
\hline 5800 & Building 754 & 51 & 043 & $L$ & 103 & $1 E 3$ & 80 & 22 & $\mathrm{H} 2$ & 1985 & $\mathrm{MB01}$ \\
\hline 5800 & Building 781 & 51 & 043 & L & 24 & $1 \mathrm{EO}$ & 50 & 22 & $\mathrm{H} 2$ & 1955 & MB14 \\
\hline 5800 & Building 800 & 51 & 043 & $L$ & 29 & 1 EO & 50 & 22 & $\mathrm{H} 2$ & 1955 & MB14 \\
\hline 5800 & Building 810 & 51 & 043 & $L$ & 77 & $1 E 0$ & 50 & 22 & $\mathrm{H} 2$ & 1955 & MB13 \\
\hline 5800 & Building $820 / 830$ & 51 & 043 & $L$ & 171 & 2 EO & 50 & $\mathrm{Z2}$ & $\mathrm{H} 2$ & 1955 & MB13 \\
\hline
\end{tabular}

Page 5 


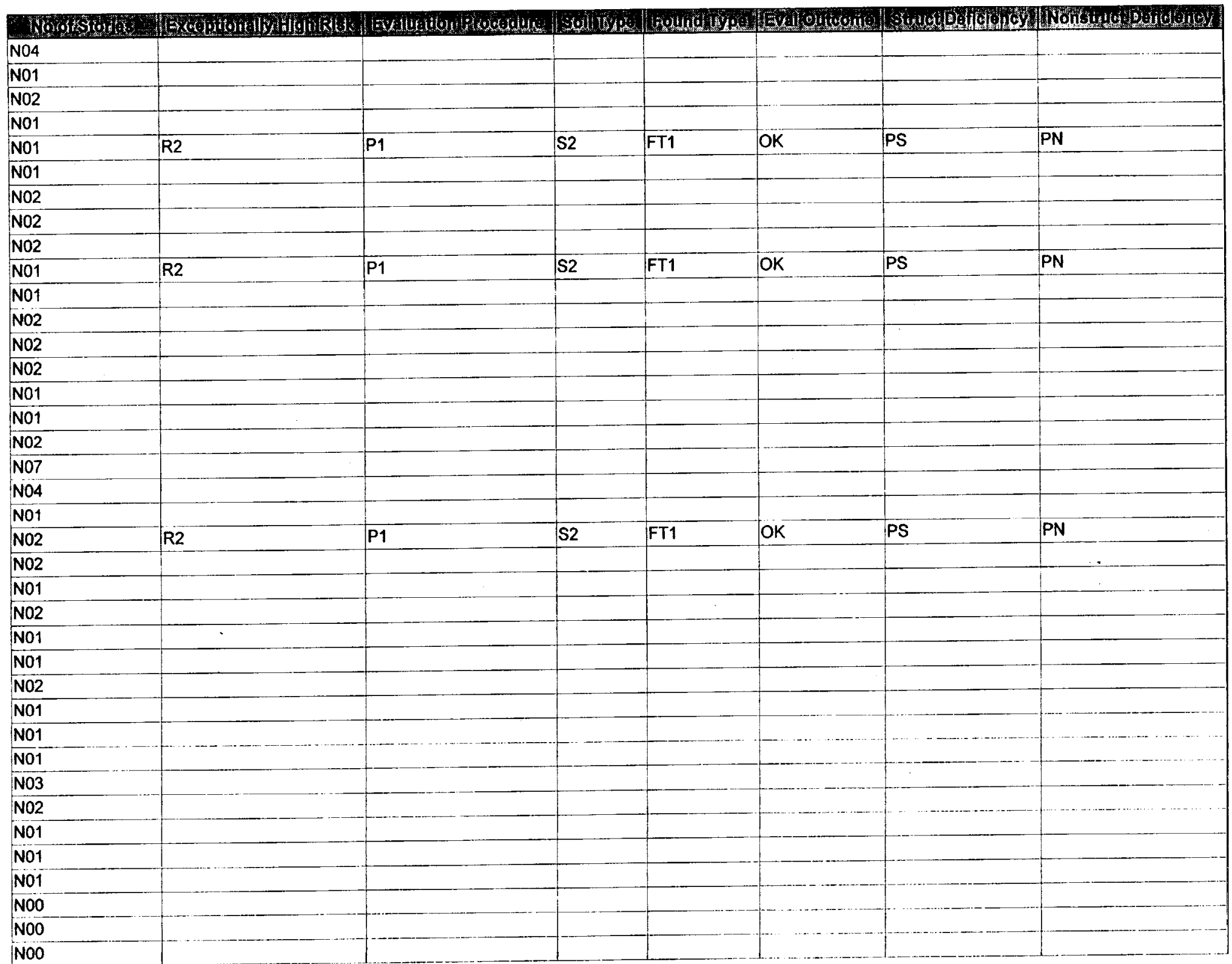

Page 6 


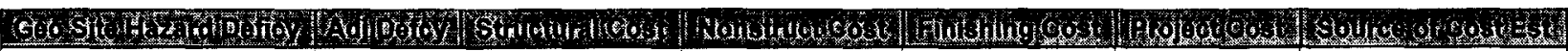

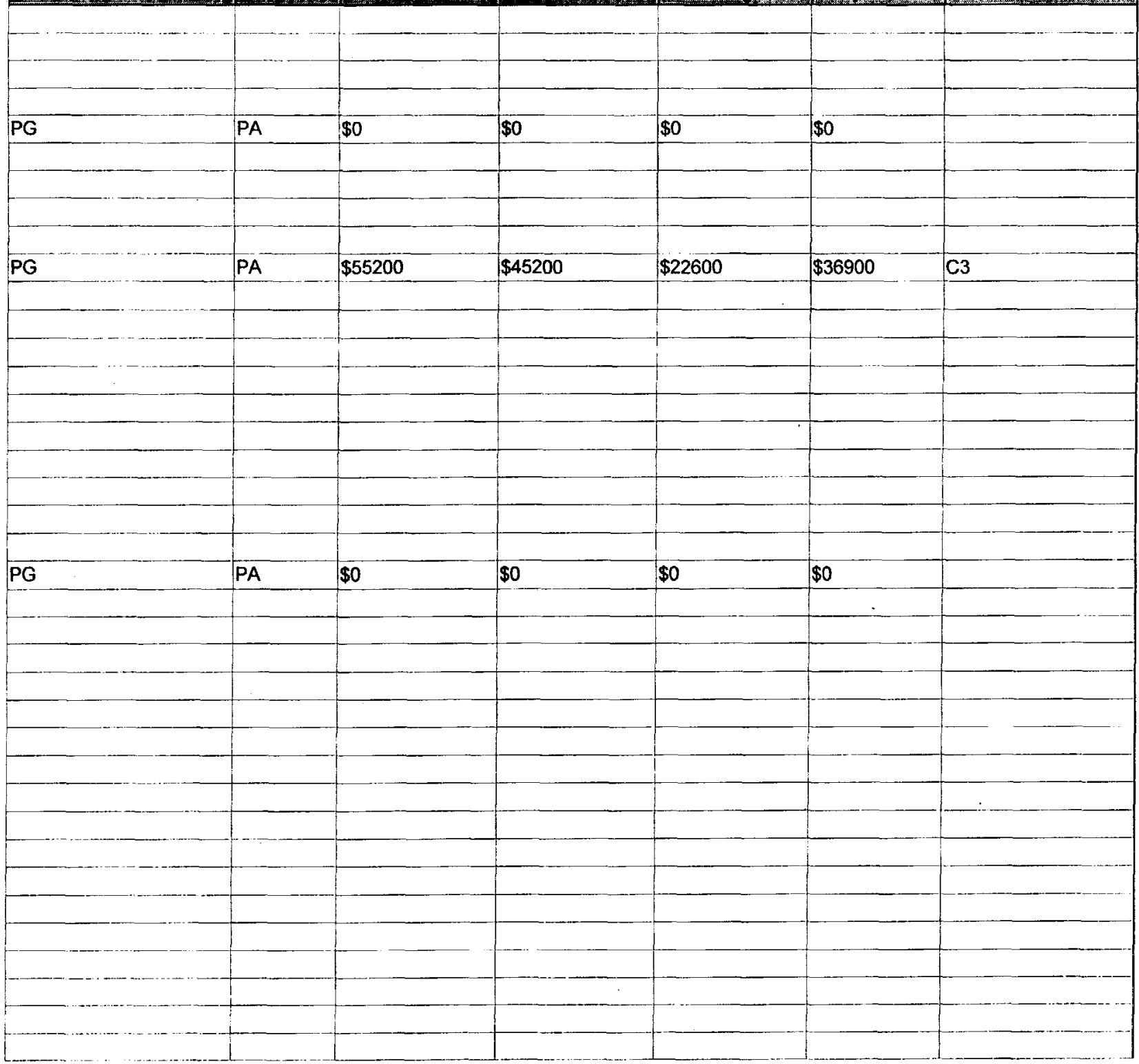

Page 7 


\begin{tabular}{|l|}
\hline \\
\hline Maintenance Building \\
\hline Guardhouses \\
\hline Guardshack \\
\hline Firestation \\
\hline \\
\hline \\
\hline Struct. passed marginally. Recommended for rehabilitation. \\
\hline Cafeteria - seats 250-300 \\
\hline \\
\hline Heliport \\
\hline Communication \\
\hline Picnic Shelter \\
\hline \\
\hline Poured reinforced concrete walls \\
\hline Poured reinforced concrete walls and roof \\
\hline \\
\hline
\end{tabular}




\begin{tabular}{|c|c|c|c|c|c|c|c|c|c|c|c|}
\hline $\mathrm{Ag}_{1030}$ & 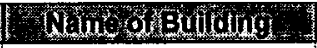 & S4000 & Wol & soduid & 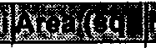 & 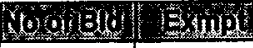 & octulans & Essoughog & Hothode & Hofos & 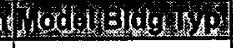 \\
\hline 5800 & Building A & 24 & 021 & $L$ & 3,091 & 1 E0 & 30 & $\mathrm{z2}$ & $\mathrm{H} 2$ & 1965 & MB10 \\
\hline 5800 & Building B & 24 & 021 & $\mathrm{~L}$ & 541 & $1 E 0$ & 80 & 22 & $\mathrm{H} 2$ & 1956 & MB15 \\
\hline 5800 & Building C & 24 & 021 & $L$ & 2,492 & 1/E0 & 30 & 22 & $\mathrm{H} 2$ & 1956 & MB10 \\
\hline 5800 & Building C-West & 24 & 021 & $L$ & 4,923 & $1 \mid E 7$ & 30 & $\mathrm{Z2}$ & $\mathrm{H} 2$ & 1995 & $\mathrm{MB} 14$ \\
\hline 5800 & Building D & 24 & 021 & L & 2,665 & 1 EO & 30 & 22 & $\mathrm{H} 2$ & 1924 & MB15 \\
\hline 5800 & Building $\mathrm{E}$ & 24 & 021 & $L$ & 3,252 & 1 EO & 10 & 22 & $\mathrm{H} 2$ & 1923 & MB15 \\
\hline 5800 & Building $F$ & 24 & 021 & $L$ & 1,875 & 1 EO & 30 & 22 & $\mathrm{H} 2$ & 1926 & MB15 \\
\hline 5800 & Building G & 24 & 021 & $\mathrm{~L}$ & 649 & 1EO & 30 & $\mathrm{Z2}$ & $\mathrm{H} 2$ & 1948 & MB15 \\
\hline 5800 & Building $\mathrm{H}$ & 24 & 021 & $L$ & 1,871 & 1 EO & 10 & 22 & $\mathrm{H} 2$ & 1923 & MB15 \\
\hline 5800 & Building I & 24 & 021 & L & 3,344 & $1 E 7$ & 50 & $Z 2$ & $\mathrm{H} 2$ & 1996 & MB07 \\
\hline 5800 & Building J & 24 & 021 & $L$ & 4,243 & 1 EO & 23 & 22 & $\mathrm{H} 2$ & 1965 & MB10 \\
\hline 5800 & Building $\mathrm{K}$ & 24 & 021 & $L$ & 3,786 & $1 E 0$ & 23 & $Z 2$ & $\mathrm{H} 2$ & 1890 & MB15 \\
\hline 5800 & Building L & 24 & 021 & $L$ & 1,065 & 1EO & 30 & 22 & $\mathrm{H} 2$ & 1959 & MB10 \\
\hline 5800 & Building M & 24 & 021 & $L$ & 678 & 1)EO & 23 & 22 & $\mathrm{H} 2$ & 1960 & MB14 \\
\hline 5800 & Building $N$ & 24 & 021 & $L$ & 4,449 & 1 E0 & 10 & 22 & $\mathrm{HI}$ & 1870 & MB15 \\
\hline 5800 & Building $\mathrm{O}$ & 24 & 021 & $L$ & 1,428 & $1 / E 0$ & 80 & 22 & $\mathrm{HI}$ & 1839 & MB15 \\
\hline 5800 & Building $P$ & 24 & 021 & $L$ & 280 & 1 E0 & 80 & 22 & $\mathrm{H} 2$ & 1960 & MB16 \\
\hline 5800 & Building Q & 24 & 021 & L & 948 & 1 EO & 40 & $\mathrm{Z2}$ & $\mathrm{H1}$ & 1880 & MB15 \\
\hline 5800 & Building $\mathbf{R}$ & 24 & 021 & $L$ & 459 & 1 EO & 23 & $\mathrm{z2}$ & $\mathrm{H} 2$ & 1950 & MB15 \\
\hline 5800 & Building S & 24 & 021 & $\mathrm{~L}$ & 626 & 1)E0 & 80 & $\mathrm{Z2}$ & $\mathrm{H} 2$ & 1926 & MB15 \\
\hline 5800 & Building $\mathrm{T}$ & 24 & 021 & $L$ & 110 & 1 EO & 10 & 22 & $\mathrm{H} 2$ & 1960 & MB15 \\
\hline 5800 & Building U & 24 & 021 & $L$ & 156 & 10 E1 & 80 & $\mathbf{Z 2}$ & $\mathrm{H} 2$ & 1982 & MB16 \\
\hline 5800 & Building V & 24 & 021 & $L$ & 90 & $1 E 7$ & 60 & $\mathbf{Z 2}$ & $\mathrm{H} 2$ & 1992 & MB13 \\
\hline 5800 & Denton Federal Regional & 48 & 121 & $L$ & 5,110 & 1 E0 & 29 & $Z 1$ & $\mathrm{H} 2$ & 1964 & MB16 \\
\hline 5800 & Denton VSAB \#2 & 48 & 121 & $L$ & 1,858 & $1 E 0$ & 50 & $\mathrm{z1}$ & $\mathrm{H} 2$ & 1993 & MB04 \\
\hline 5800 & Denton VSAB-Old & 48 & 121 & $L$ & 4,738 & $1 E 0$ & 10 & 21 & $\mathrm{H} 2$ & 1985 & MB04 \\
\hline 5800 & Fire Pump Station & 24 & 021 & $L$ & 372 & $1 E 0$ & 50 & 22 & $\mathrm{H} 2$ & 1981 & MB16 \\
\hline 5800 & Maynard Federal Region & 25 & 017 & $M$ & 7,432 & 1 EO & 29 & 21 & $\mathrm{H} 2$ & 1968 & MB16 \\
\hline 5800 & Maynard VSAB & 25 & 017 & $M$ & 3,716 & 1 EO & 50 & 21 & $\mathrm{H} 2$ & 1988 & MB05 \\
\hline 5800 & Morton Buildings & 24 & 021 & $L$ & 316 & $2 E 1$ & 40 & 22 & $\mathrm{H} 2$ & 1980 & $\mathrm{MB02}$ \\
\hline 5800 & Olney Federal Support C & 24 & 031 & $L$ & 6,039 & 1EO & 29 & $\mathrm{Z1}$ & $\mathrm{H} 2$ & 1970 & MB16 \\
\hline 5800 & Olney Storage & 24 & 031 & $L$ & 139 & 2 E1 & 40 & 22 & $\mathrm{H}_{2}$ & 1955 & MB15 \\
\hline 5800 & Reception and Breakroo & 48 & 121 & $L$ & 285 & $1 / E 3$ & 60 & $\mathrm{Z2}$ & $\mathrm{H} 2$ & 1964 & MB05 \\
\hline 5800 & Sewage Pumping Statio & 24 & 021 & $L$ & 15 & 1E0 & 50 & 22 & $\mathrm{H} 2$ & 1940 & MB16 \\
\hline 5800 & Sewage Pumping Statio & 24 & 021 & $L$ & 15 & $1 E 0$ & 50 & $z 2$ & $\mathrm{H} 2$ & 1995 & MB16 \\
\hline 5800 & Storage Building - East & 48 & 121 & $L$ & 223 & $1 \mathrm{E1}$ & 40 & 22 & $\mathrm{H} 2$ & 1990 & $\mathrm{MBO4}$ \\
\hline 5800 & Storage Building - West & 48 & 121 & L & 223 & 1E1 & 40 & $\mathrm{Z2}$ & $\mathrm{H} 2$ & 1990 & MB04 \\
\hline
\end{tabular}




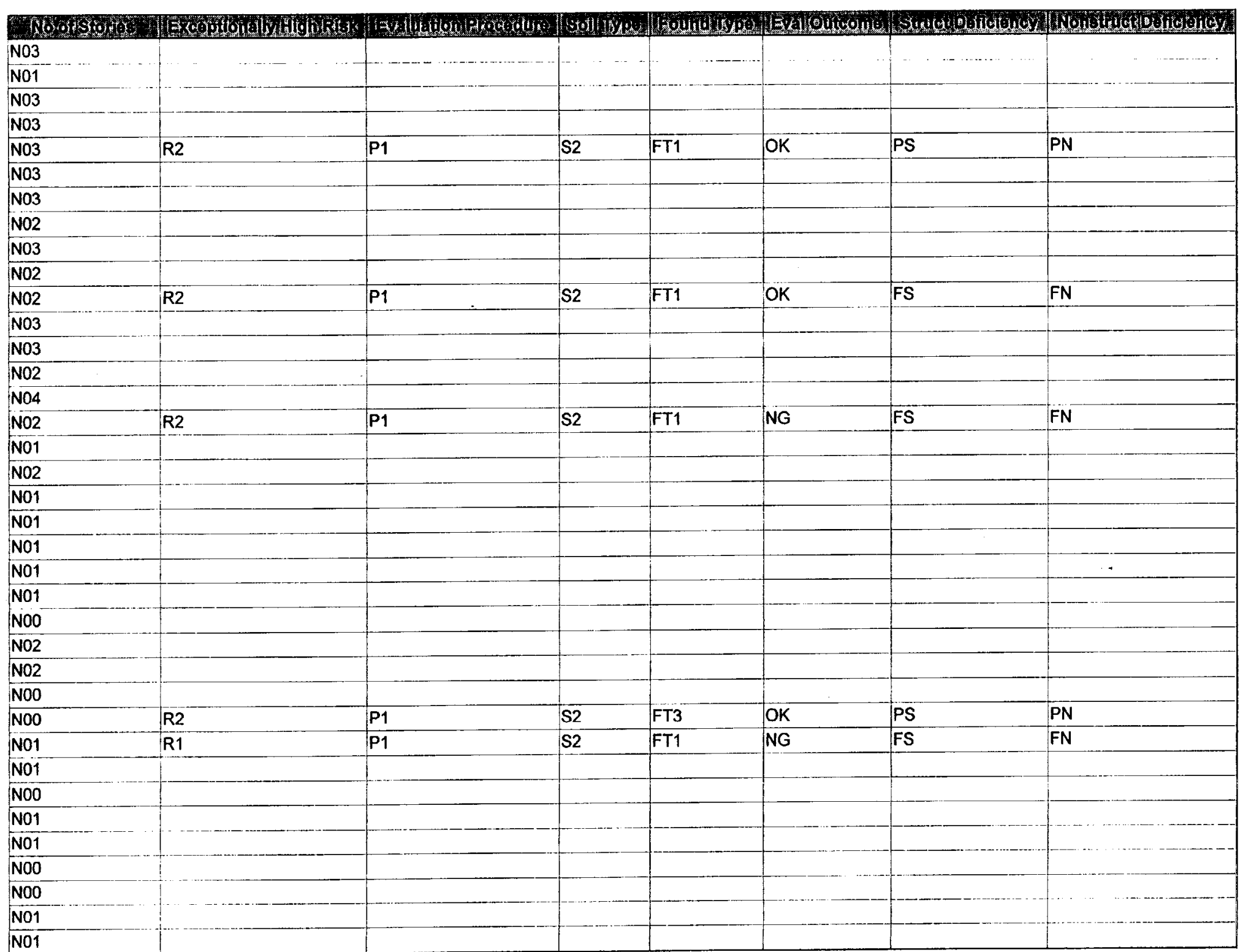




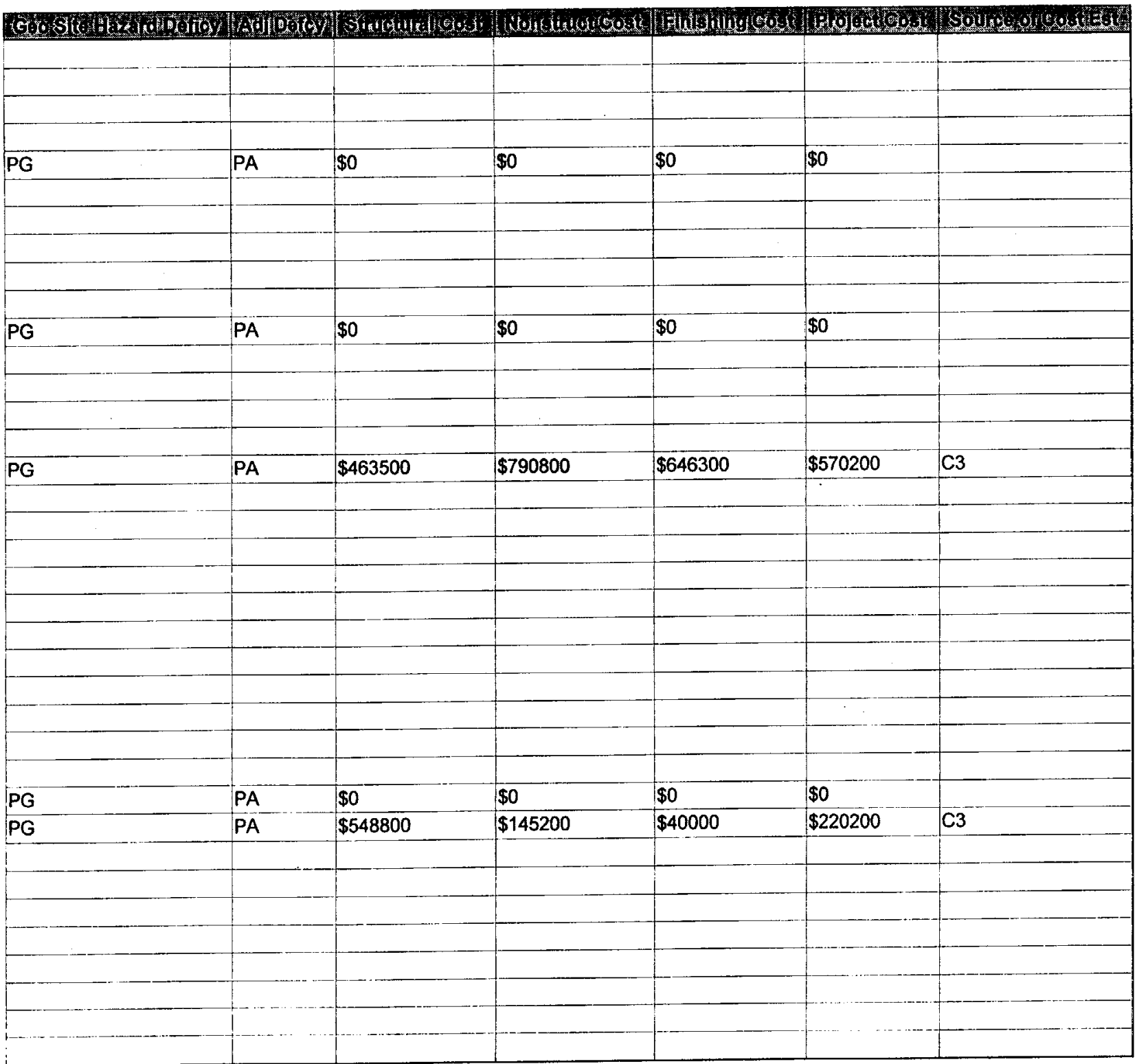




\begin{tabular}{|l|}
\hline \\
\hline Recreation Building \\
\hline \\
\hline Eligible for historic registry but not registered \\
\hline Auditorium seats approx. 500; Eligible for historic registry but not registered \\
Eligible for historic registry but not registered \\
\hline \\
\hline Contains recreation area (swimming pool, basketball court, weight room) \\
\hline Design looked at Map Area 1 in BOCA and NEHRP \\
\hline Contains an auditorium and offices \\
\hline Cafeteria seats about $350 ;$ eligible for historic registration but not registered \\
\hline \\
\hline \\
\hline Chapel; historical building \\
\hline Log Cabin; Holds 150-200 people for recreational purposes. \\
\hline \\
\hline \\
\hline Eligible for historic registry but not registered; Planned renovations for compu \\
\hline
\end{tabular}

